JOÃO FERREIRA NETTO

\title{
MODELO DE SIMULAÇÃO PARA DIMENSIONAMENTO DA FROTA DE CONTÊINERES MOVIMENTADA POR NAVIOS EM ROTA DEDICADA
}

SÃO PAULO 
JOÃO FERREIRA NETTO

\section{MODELO DE SIMULAÇÃO PARA DIMENSIONAMENTO DA FROTA DE CONTÊINERES MOVIMENTADA POR NAVIOS EM ROTA DEDICADA}

Dissertação apresentada à Escola Politécnica da Universidade de São Paulo para obtenção do título de Mestre em Engenharia.

Área de Concentração:

Engenharia de Sistemas Logísticos

Orientador: Prof. Dr. Rui Carlos Botter

SÃO PAULO

2012 


\section{DEDICATÓRIA}

Ao Dr. Messias e à Dra. Marisa,

porque sem eles o sonho não seria realizado. 


\section{AGRADECIMENTOS}

Agradeço, primeiramente, a Deus. Por me manter firme em minha fé e por guiar minha caminhada até este momento.

Ao Prof. Dr. Rui Carlos Botter, pelas portas que me abriu, pelos seis anos de convivência, pelos ensinamentos proporcionados, pela orientação, pela amizade e pela confiança que sempre depositou em mim.

Aos amigos Afonso Medina e Newton Narciso, pela colaboração intelectual, pela amizade, pela coorientação e por auxiliar no meu crescimento profissional. Aos meus companheiros de trabalho, e eternos amigos, Thiago Brito, Rodolfo e Edson Trevisan, pelas trocas de ideias, experiências, risadas, discussões e conversas ao longo de todos esses anos.

A todos os membros do Centro de Inovação em Logística e Infraestrutura Portuária da USP, pelo companheirismo e suporte dispensado em todas as horas.

Aos meus pais, Messias e Marisa, por depositarem em mim sua confiança, serem meu porto seguro e por proporcionarem as condições necessárias para que eu chegasse até aqui. Aos meus irmãos, Lucas e Matheus, por me ensinar que os alicerces de uma vida completa começam no companheirismo.

Aos familiares e amigos que sempre se mantiveram na torcida. A todos os que participaram da minha formação e contribuíram de alguma forma para que eu me tornasse o João que eu sou hoje.

Aos meus professores de Física e Matemática que, no primeiro ano do ensino médio, me mostraram que minhas habilidades levariam ao árduo, mas belíssimo, caminho da engenharia. 
"Que os vossos esforços desafiem as impossibilidades, lembrai-vos de que as grandes coisas do homem foram conquistadas do que parecia impossível." 


\section{RESUMO}

As empresas de navegação que operam com transporte de contêineres têm como desafio alocar a quantidade de navios, com características específicas (entre elas capacidade de transporte e velocidade), em uma rota dedicada, atendendo à demanda em um determinado período. Para tanto, é também necessário que sejam disponibilizados aos clientes uma frota de contêineres, que serão retirados nos depósitos de vazios, carregados nas origens e enviados aos portos de embarque para serem transportados pela frota, em ciclo fechado, aos outros terminais que compõem a rota, de acordo com a matriz de cargas de cada navio.

Esse trabalho apresenta um modelo de simulação para o dimensionamento da quantidade de contêineres necessária para operar junto a uma frota de navios que atende determinada rota (em ciclo fechado) ao mesmo tempo em que se consideram as operações de carregamento e esvaziamento dos contêineres junto aos clientes, em terra. Além deste modelo de simulação, apresenta-se um processo de busca por melhores soluções apresenta resultados que minimizem a frota de contêineres à disposição da empresa.

Os principais parâmetros estudados são: o tempo de retenção de contêineres nos clientes (seja para carregamento ou descarregamento dos mesmos), os estoques iniciais de contêineres nos portos e o reposicionamento de contêineres vazios entre os terminais que compõem a rota. Os resultados apresentados mostraram que a técnica de simulação aplicada a este problema possibilitou o dimensionamento proposto, além de avaliar a sensibilidade do sistema em relação a estes principais parâmetros.

Palavras chave: transporte, contêiner, cabotagem, simulação, imbalance, sistemas logísticos. 


\begin{abstract}
Shipping companies operating with container transportation have the challenge of allocating an amount of ships with specific features (including transport capacity and speed), in determined route, and attend the demand in a given period. For such, it is also necessary to make a container fleet available to the customers, which will be removed in the empty warehouse, loaded in the origins and sent to ports to be transported by the ships, in closed cycle, to other terminals that compose the route, according to the loading matrix of each ship.

This work presents a simulation model to dimension the quantity of containers required to operate with a ship fleet that attends determined route (in closed loop) and at the same time considers the loading operations and emptying of containers with customers, on land. It is presented a process of searching for better solutions provides results that minimize the container fleet at its disposal

The main parameters studied are: retention time of containers with clients (either for loading or unloading operations), initial container stocks in ports and repositioning of empty containers between the terminals that compose the route. The results showed that the simulation technique applied to this problem allowed the proposed dimensioning, in addition to assessing the sensitivity of the system in relation to these key parameters.
\end{abstract}

Key words: transport, container, short seashipping, simulation, imbalance, logistics systems. 


\section{LISTA DE FIGURAS}

Figura 1-1: Participação dos tipos de cargas nos serviços regulares de transporte marítimo (liner) - FONTE: Costa, Hamburg Sud (2006) 4

Figura 1-2: Crescimento dos volumes mundiais de contêineres (Fonte: Drewry, 2006 adaptado por Costa (2006))

Figura 1-3: Distribuição da idade da frota mundial de portas-contêineres (Fonte: UNCTAD, 2010) 6

Figura 1-4: Terminal de contêineres do Porto de Rotterdam - FONTE: Costa (2006) 7

Figura 2-1: Evolução do índice de conteinerização. Fonte: ANTAQ 16

Figura 2-2: Estimativa do fluxo de carga nas principais rotas (Fonte: UNCTAD, 2008) 18

Figura 2-3: Crescimento do comércio internacional de conteinerizados, 19862008 (Fonte: UNCTAD) 18

Figura 2-4: Representação gráfica do ciclo logístico dos contêineres (Fonte: 0 autor) 21

Figura 3-1: Fluxograma da lógica de operação de navios - Yaguiu (2006) 30

Figura 3-2: Fluxograma da lógica de descarregamento dos contêineres cheios Yaguiu (2006) 31

Figura 3-3: Fluxograma da lógica de manuseio dos contêineres vazios - Yaguiu (2006) 32

Figura 3-4: Sequência de atividades realizadas pelo modelo desenvolvido por Bandeira (2005) (Fonte: Bandeira (2005)) 47

Figura 4-1: Processo de criação de um modelo de simulação 63

Figura 4-2: Representação do mecanismo de reposicionamento de contêineres vazios 70

Figura 4-3: Representação da quantidade de contêineres carregados e descarregados em cada porto 
Figura 4-4: Modelo conceitual da lógica de circulação de navios entre os portos 76

Figura 4-5: Modelo conceitual da lógica de circulação de contêineres em terra

Figura 4-6: Amostra da interface de entrada de dados - inserção das sequências de visitas dos portos pelos navios 79

Figura 4-7: Amostra da interface de entrada de dados - inserção das distâncias entre os portos

Figura 4-8: Amostra da interface de entrada de dados - inserção dos estoques iniciais (valores fictícios) em cada porto 84

Figura 5-1: Localização dos portos da rota na costa brasileira. FONTE: Ministério dos Transportes 88

Figura 5-2: Representação do mecanismo de reposicionamento de contêineres vazios 90

Figura 5-3: Quantidades de contêineres cheios a bordo em cada trecho do ciclo de viagens 90

Figura 5-4: Representação da rota seguida pelos navios 91

Figura 5-5: Gráfico do comportamento do estoque de contêineres cheios "in" nos portos - cenário inicial 100

Figura 5-6: Gráfico do comportamento do estoque de contêineres cheios "out" nos portos - cenário inicial 101

Figura 5-7: Gráfico do comportamento do estoque de contêineres vazios nos portos - cenário inicial 102

Figura 5-8: Gráfico do comportamento do estoque de contêineres cheios "in" nos portos - cenário otimizado 110

Figura 5-9: Gráfico do comportamento do estoque de contêineres cheios "out" nos portos - cenário otimizado 111

Figura 5-10: Gráfico do comportamento do estoque de contêineres vazios nos portos - cenário otimizado 
Figura 5-11: Comparação entre gráficos de comportamento de estoque dos cenários inicial e otimizado

Figura 5-12: Gráfico do comportamento do estoque de contêineres vazios nos portos - cenário de análise da capacidade reduzida de reposicionamento de vazios 120

Figura 5-13: Gráfico - tamanho da frota de contêineres em função da frota de navios e da matriz de carga desejada 122 


\section{LISTA DE TABELAS}

Tabela 2-1: Diferenças entre os mercados de linha regular e não regular (Fonte: BNDES)

Tabela 2-2: Frota Mundial utilizada em liner shipping (Fonte: Lloyd's Register $\mathrm{Jul} / 2009)$ 15

Tabela 2-3: Tamanho da frota a ser incorporada em serviços de Liner Shipping (Fonte: Lloyd's Register - Jul/2009) 15

Tabela 2-4: Evolução anual, por natureza de carga (em toneladas). Fonte: ANTAQ 16

Tabela 2-5: Quantidade de contêineres em cais públicos (Fonte: ANTAQ) 17

Tabela 2-6: Evolução da frota de navios porta-contêineres (Fonte: UNCTAD) 19

Tabela 5-1: Matriz de cargas dos navios - cenário base inicial 89

Tabela 5-2: Matriz de distância entre os portos considerados 92

Tabela 5-3: Estoque inicial de contêineres do cenário inicial 97

Tabela 5-4: Quantidades diárias e anuais de contêineres necessários e desembarcados em cada porto 98

Tabela 5-5: Resultados obtidos na simulação do cenário inicial 99

Tabela 5-6: Estoque inicial de contêineres do cenário melhorado (busca da melhor solução) com perdas 105

Tabela 5-7: Resultados obtidos na simulação do cenário melhorado com perda de transporte 106

Tabela 5-8: Estoques de contêineres obtidos em experimentos com fator multiplicador da perda na função objetivo 107

Tabela 5-9: Estoque inicial de contêineres do cenário otimizado 108

Tabela 5-10: Resultados obtidos na simulação do cenário otimizado 109 Tabela 5-11: Quantidades anuais e diárias de contêineres necessários e desembarcados nos portos para as velocidades estudadas 115 Tabela 5-12: Estoque inicial de contêineres para os cenários de análise do efeito da velocidade dos navios da frota 116 Tabela 5-13: Estoque inicial de contêineres para os cenários de análise do efeito da retenção de contêineres em terra 
Tabela 5-14: Estoque inicial de contêineres para o cenário de análise da capacidade reduzida de reposicionamento

Tabela 5-15: Matriz de cargas dos navios para cada viagem - cenário base inicial 121

Tabela 5-16: Resultados obtidos na simulação de cenários com variação do tamanho da frota de navios e matriz de carga a ser atendida 122 Tabela 5-17: Quantidade de movimentos de contêineres entre os portos da rota em função da matriz de carga utilizada e do tamanho da frota de navios 123 Tabela 5-18: Relação entre quantidade de contêineres movimentados anualmente e tamanho da frota de contêineres 124 


\section{SUMÁRIO}

1. INTRODUÇÃO

1.1. Importância do tema __ 4

1.2. Abrangência e premissas do trabalho __ 8

1.3. Delineamento do trabalho __ 9

2. O TRANSPORTE DE CONTÊINERES, SUAS CARACTERÍSTICAS E A LOGÍSTICA DE CONTÊINERES VAZIOS___ 11

2.1. O contêiner 11

2.1.1. O mercado liner __ 13

2.1.2. Panorama atual do transporte de contêineres___ 15

2.2. A logística do contêiner vazio __ 19

2.2.1. Imbalance _ 20

2.2.2. Contêineres vazios__ 21

3. REVISÃO DA BIBLIOGRAFIA___ 26

3.1. Revisão de metodologias - DIMENSIONAMENTO DA FROTA DE CONTÊINERES _ 26

3.2. Revisão de metodologias - REPOSICIONAMENTO DE CONTÊINERES VAZIOS 38

3.3. Conclusão da revisão bibliográfica 59

4. MODELO DE SIMULAÇÃO DA MOVIMENTAÇÃO DE CONTÊINERES CHEIOS E VAZIOS COM FROTA DE NAVIOS EM ROTA DEDICADA 62

4.1. Simulação 62 
4.2. Introdução à modelagem DE SIMULAÇÃO PARA O DIMENSIONAMENTO DA FROTA DE CONTÊINERES ___ 64

4.2.1. Submodelo: Circulação dos navios ___ 64

4.2.2. Submodelo: Circulação dos contêineres em terra___ 72

4.2.3. Dependência entre os submodelos __ 73

4.3. Modelo conceitual __ 74

4.4. Interface de entrada de dados___ 79

4.4.1. Utilizando a interface de entrada de dados e o modelo para construção de cenários e análises de sensibilidade

\section{APLICAÇÃO DO MODELO DE SIMULAÇÃO E OS RESULTADOS OBTIDOS 86}

5.1. Dados de entrada para o cenário base 87

5.2. Indicadores fornecidos pelo modelo de simulação 95

5.3. Resultados da simulação: Processamento inicial a partir de estoque suficiente para atender à demanda integralmente 96

5.4. Busca da melhor solução para o problema: dimensionamento da frota de contêineres minimizando perdas de transporte através de multiplicação do termo na função objetivo 102

5.4.1. A ferramenta de busca da melhor solução OptQuest 103

5.4.2. Dimensionamento da frota de contêineres: minimização dos estoques iniciais nos portos 104

5.5. Análises de sensibilidade 113

5.5.1. Variação da velocidade dos navios 113

5.5.2. Variações no tempo de retenção dos contêineres nos portos e em terra antes da movimentação 117

5.5.3. Operação diminuindo a capacidade de reposicionamento de vazios pelos navios da frota 
5.6. Utilizando o modelo de simulação no planejamento da empresa de navegação

6. CONCLUSÕES E RECOMENDAÇÕES 


\section{INTRODUÇÃO}

O desenvolvimento tecnológico ocorrido nas últimas décadas possibilitou grandes melhorias dos meios de comunicação e transporte, possibilitando maior eficiência das trocas de informações e diminuição do tempo de deslocamento de pessoas e produtos, o que favoreceu o comércio internacional e entre regiões geograficamente distantes. Essa expansão das relações comerciais levou, também, ao crescimento do transporte marítimo de mercadorias, além da conteinerização de cargas, a partir da década de 60 (Teixeira, 2011), e o surgimento de desafios logísticos atrelados a este cenário.

Uma companhia de navegação que opera no mercado regular (liner) de transporte de contêineres trabalha com rotas definidas e uma frota de navios dedicada a essas rotas durante um período de planejamento, em geral de seis meses. Para o atendimento de uma demanda em um determinado horizonte de tempo, além de ser necessária uma frota compatível de navios, é também necessária uma frota de contêineres que estarão, carregados ou não, a bordo dos navios, em posse de clientes, em trânsito em terra e ou armazenados nos portos.

Nesse período em que a empresa de navegação aloca uma frota de navios para operar entre um determinado conjunto de portos, ela tem por base uma demanda esperada e avaliada por sua área comercial. A partir dessa previsão, a empresa de navegação monta uma matriz de carga esperada em cada porto (com as quantidades de contêineres a serem carregados), para cada embarcação, a serem transportados para seus clientes nos demais portos da rota.

Essa é uma fase de planejamento importante, pois devem existir contêineres suficientes no sistema para atender aos clientes nos portos de origem.

Em terra, os contêineres vazios são retirados nos depósitos portuários e enviados para serem carregados nos clientes antes de serem direcionados para embarque. Quando são desembarcados nos terminais, são enviados 
cheios para os clientes, para serem descarregados e devolvidos posteriormente.

Este trabalho aborda um tema considerado de grande relevância para as empresas de navegação que operam no mercado regular (liner) transportando contêineres cheios e vazios, que é a questão do estoque de contêineres à disposição dos navios e dos clientes, de tal forma que a matriz de carga esperada em cada porto seja atendida integralmente. Se não houver contêineres cheios disponíveis e prontos para serem embarcados em um navio, quando este atracar em algum porto da rota, em virtude da indisponibilidade de contêineres no sistema, ocorrerá o não cumprimento da matriz de carga, ocasionando uma perda de transporte e consequentemente de receita.

Como as matrizes de carga dos navios geralmente apresentam desequilíbrio entre contêineres entregues e contêineres recebidos pelos navios (também conhecido como "imbalance"), muitos dos portos acabam acumulando contêineres vazios, ao passo que outros sofrem com a falta destes. Para mitigar os efeitos do "imbalance", as companhias de navegação buscam realizar o reposicionamento dos vazios, levando os recipientes dos portos ofertantes para os terminais demandantes. Um reposicionamento eficiente de vazios entre os portos possibilita à companhia que se disponha de frotas menores de contêineres, além de evitar custos com leasing e perda de transporte.

As alternativas para realizar o reposicionamento destes contêineres têm sido estudadas e são fundamentais para que a quantidade total necessária de contêineres no sistema venha a ser minimizada, ao passo que a disponibilidade de espaço para transporte de contêineres cheios nos navios deve ser maximizada, aumentando as margens de lucro para as empresas de navegação.

Sendo assim, este trabalho tem como objetivo dimensionar, por meio de um modelo de simulação, uma frota de contêineres no sistema de forma que os clientes tenham recipientes para serem carregados em terra e enviados aos portos para serem embarcados nos navios e cumprindo a matriz de carga 
planejada pela empresa de navegação, considerando também 0 reposicionamento de vazios entre os portos que compõem as rotas adotadas.

Cabe ressaltar que a demanda de contêineres nos portos, refletida pela demanda de contêineres dos clientes nas regiões de influências nos portos, varia ao longo do período de planejamento da empresa de navegação.

Essa variação de demanda não é considerada pelo modelo de simulação proposto, que utiliza a matriz de carga esperada de contêineres a serem carregados em cada porto naquele horizonte de planejamento para 0 dimensionamento de contêineres necessários no sistema.

Tanto o reposicionamento de contêineres quanto o dimensionamento da frota são temas já abordados em outras pesquisas, como é apresentado na revisão bibliográfica, por diferentes métodos de pesquisa operacional. Buscou-se abordar premissas semelhantes aos trabalhos anteriormente realizados e criouse um modelo de simulação discreta para resolver o problema proposto, tratando-se, portanto, de uma nova forma de abordagem.

O modelo de simulação apresentado foi construído no software ARENA® e conta com o auxilio de uma interface construída no Microsoft Excel® para que sejam inseridos os dados necessários e se configurem dessa forma os cenários a serem simulados. Através desta interface também é possível se obter os resultados gerados pela simulação de forma clara e organizada, permitindo, inclusive, comparações entre cenários e análises de sensibilidade dos parâmetros do projeto.

A metodologia adotada foi escolhida por se tratar de uma alternativa às técnicas já utilizadas e por possibilitar um melhor detalhamento dos processos que envolvem a circulação de navios, os processos que ocorrem em terra e a administração dos estoques. Dentre todos os trabalhos e pesquisas verificados, nenhum utilizou a simulação como ferramenta principal para determinar a frota de contêineres de uma empresa de navegação. Além disso, o problema possui natureza estocástica e a simulação de eventos discretos é uma ferramenta indicada para este tipo de situação. As técnicas de simulação utilizadas facilitam a modelagem de algumas restrições que são mais complexas de serem explicitadas em uma modelagem analítica. 
No modelo de simulação, é possível inserir regras para decidir como reposicionar os contêineres vazios disponíveis naquele porto e que podem ser transportados aos demais portos da rota, que possuem demanda por vazios. Definido o horizonte de planejamento adequado, resolve-se o problema de alocação de contêineres vazios de modo a obter a menor frota de contêineres que atenda a requisitos mínimos de atendimento da matriz de carga desejada no mesmo período.

\subsection{IMPORTÂNCIA DO TEMA}

O tema proposto para este trabalho foi escolhido por ser considerado de grande relevância e importância para muitos setores da economia mundial. Para justificar essa afirmação, pode-se citar a grande participação do transporte marítimo de cargas e utilização do mercado liner no comercio internacional.

Segundo dados de Costa (2006), cerca de 7,5 bilhões de toneladas de cargas eram transportadas por navios alocados no serviço regular no ano de 2006, e cerca de $15 \%$ deste total eram contêineres, como mostra a Figura 1-1.

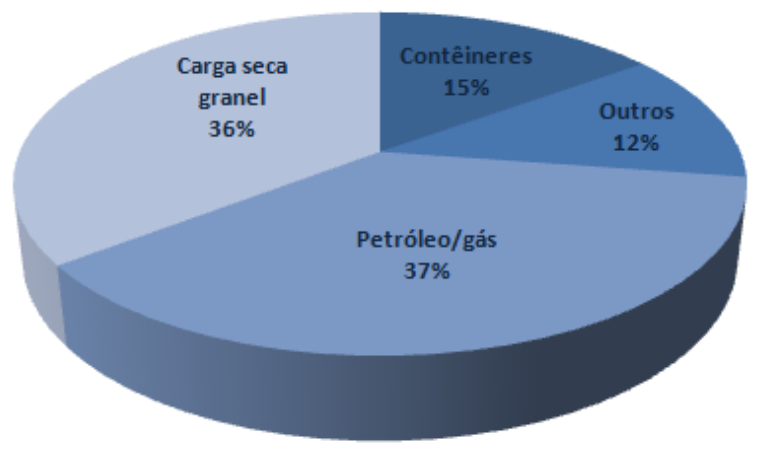

Figura 1-1: Participação dos tipos de cargas nos serviços regulares de transporte marítimo (liner) - FONTE: Costa, Hamburg Sud (2006) 
Estes valores são apenas uma amostra da grande utilização do transporte de contêineres em um cenário de economia global e grande fluxo de mercadorias por exportações e importações.

O transporte de contêineres pode ser analisado em particular, pois representa um tipo de transporte que continua crescendo devido a todas as suas vantagens e à possibilidade de se carregar diferentes tipos de carga em seu interior. A Figura 1-2 apresenta as estimativas de crescimento de contêineres entre 1990 e 2010, confirmando esse crescimento nos volumes mundiais transportados.

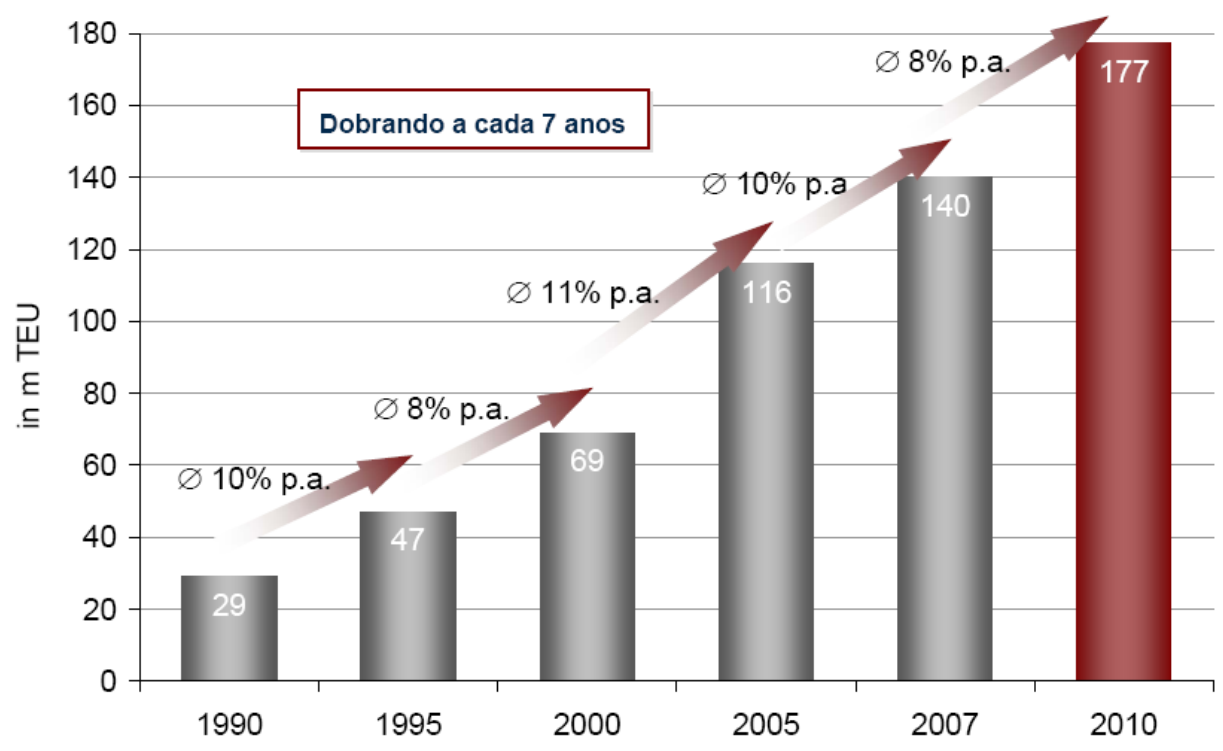

Figura 1-2: Crescimento dos volumes mundiais de contêineres (Fonte: Drewry, 2006 adaptado por Costa (2006))

Segundo a UNCTAD (2010), no ano de 2010 a frota mundial de portacontêineres era capaz de movimentar 169 milhões de toneladas de cargas. Ainda segundo a UNCTAD (2010), os maiores navios em operação no ano de 2010 possuíam capacidade nominal para transportar 14.000 TEU's e pertenciam à MSC. Pode-se observar na Figura 1-3 que a frota de portascontêineres é uma frota que pode ser considerada nova, visto que nos últimos anos (principalmente, a partir de 2004), muitos navios novos entraram em operação para o transporte de contêineres. 


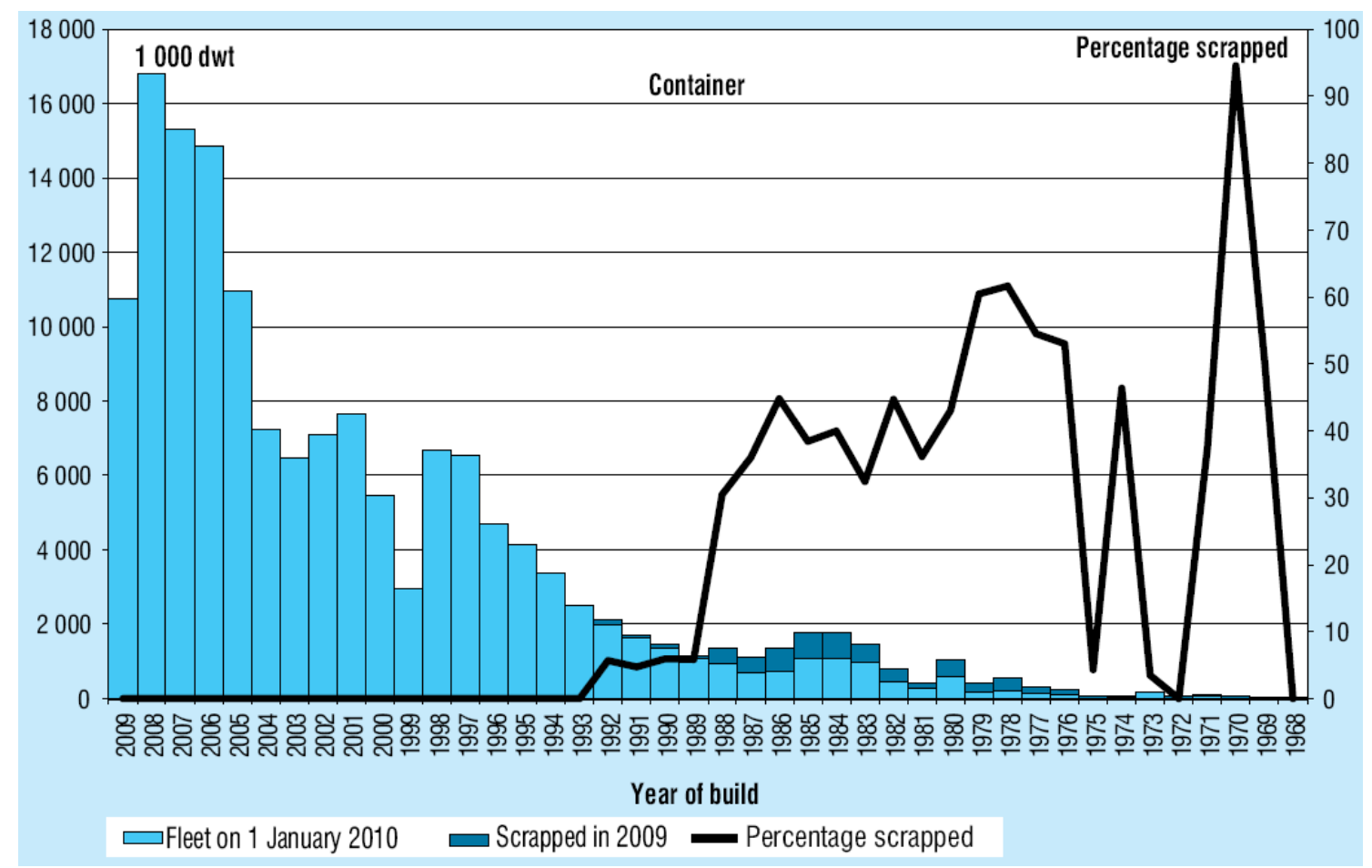

Figura 1-3: Distribuição da idade da frota mundial de portas-contêineres (Fonte: UNCTAD, 2010)

A principal rota de tráfego dos contêineres é a chamada Ásia-Europa, na qual os contêineres são transportados desde a Ásia até os países da Europa e América do Norte. Atualmente, os portos com maior movimentação de cargas conteinerizadas encontram-se no continente asiático, como os portos de Cingapura, Xangai e Hong Kong.

Outro fator que atribui grande utilidade aos contêineres é a possibilidade de utilizá-lo em diferentes modais sem a necessidade de muitas adaptações. A padronização de equipamentos para movimentação dos contêineres e desenvolvimento dos terminais também favorecem 0 transporte destes equipamentos. A Figura 1-4 ilustra um terminal de contêineres bem equipado e de grande movimentação. 


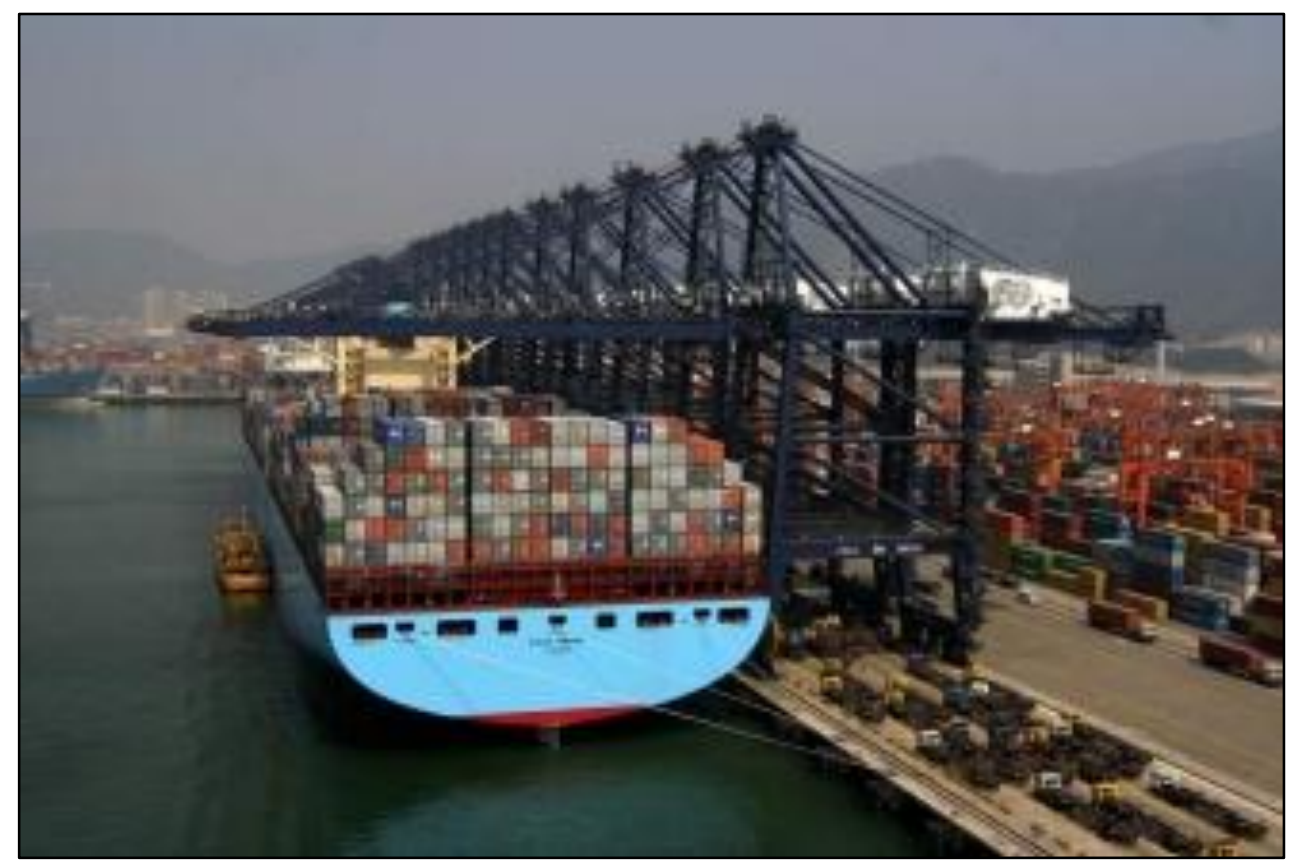

Figura 1-4: Terminal de contêineres do Porto de Rotterdam - FONTE: Costa (2006)

O mercado de transporte de contêineres, embora seja amplo e muito importante para o comércio entre os países, está concentrado na mão de poucas empresas, devido aos grandes custos envolvidos e dificuldades de operação. Esse mercado restrito faz com que as empresas busquem possibilidades de oferecer preços atrativos continuamente.

Ferramentas que possibilitem a diminuição de custos, eficiência no transporte e diminuam os tempos de ciclo das viagens são alvo de grandes pesquisas e análises por parte dos grandes armadores. Uma das maneiras vistas como sendo de grande potencial para a redução de custos é a utilização de uma frota de contêineres otimizada que atenda uma demanda prevista, e para tanto é necessário o aperfeiçoamento das operações relacionadas à logística de contêineres vazios, principal tema abordado por este trabalho.

Se a companhia de navegação decidir por uma frota de contêineres muito grande de tal forma que os estoques de contêineres vazios em cada porto atenda às necessidades dos clientes naquela região de influência, pagará um custo elevado, pois, comprar ou efetuar leasing de contêineres gera custos consideráveis para a empresa. Por outro lado, como é sabido que existe desbalanceamento nos portos, aproveitar espaço disponível nos navios para 
fazer o reposicionamento dos vazios poderá reduzir a quantidade de contêineres total necessária para atendimento da demanda.

Reduzir os custos através de maior eficiência nas operações é vantajoso para todas as empresas envolvidas no negócio e pode gerar benefícios para todos os envolvidos na cadeia logística, como, por exemplo, uma queda nos preços ocasionada por menores gastos com fretes.

\subsection{ABRANGÊNCIA E PREMISSAS DO TRABALHO}

Esta dissertação de mestrado apresenta um modelo de simulação matemática por eventos discretos para colaborar com a resolução de um problema de planejamento de logística de contêineres cheios e vazios, considerando o reposicionamento dos vazios, mas buscando o dimensionamento do total de contêineres necessários para atendimento da matriz de carga esperada por navio em cada porto.

O modelo de simulação apresentado neste trabalho foi aplicado para um caso real definido por uma importante companhia de navegação com atuação no Brasil. Esta empresa forneceu todas as informações necessárias para a construção do cenário a ser simulado, como as características das rotas (portos visitados, sequência de viagens, distâncias entre os portos), características dos navios (velocidade, capacidade, matriz de carga atendida por cada navio em uma viagem), características dos portos e informações sobre as operações em terra.

Durante a simulação dos cenários definidos pela empresa, o modelo ainda busca o reposicionamento de contêineres vazios entre os portos, de acordo com regras pré-definidas e considerando as características de oferta e demanda por vazios individualmente.

Como simplificação, o modelo considera um tipo único de contêiner. Os principais parâmetros utilizados para as simulações e análises de sensibilidade são a velocidade dos navios, as produtividades nos portos, o tempo médio de 
retenção dos contêineres em terra e a avaliação dos estoques iniciais de contêineres, cheios e vazios, em todos os portos.

O objetivo da pesquisa é utilizar a técnica de simulação de eventos discretos para representar a circulação de uma frota de navios porta-contêineres em rotas pré-definidas e a circulação de contêineres cheios e vazios em terra, para assim dimensionar eficientemente a frota de contêineres, considerando 0 reposicionamento otimizado de contêineres vazios entre os portos visitados e buscando atender uma matriz de carga conhecida em determinado horizonte de tempo. Deseja-se utilizar o reposicionamento como uma ferramenta que contribua com a minimização da frota de contêineres disponibilizada.

Este trabalho deve contribuir, dessa forma, com uma ferramenta útil para a definição de estratégias adotadas pelas companhias de navegação no que se refere à frota necessária de contêineres, os estoques destes nos portos e as políticas de reposicionamento que podem ser adotadas.

\subsection{DELINEAMENTO DO TRABALHO}

Esta dissertação está divido em capítulos, descritos a seguir:

O capitulo 1 introduz o problema proposto e justifica a importância a este atribuída, mostrando rapidamente qual o conteúdo encontrado ao longo deste trabalho, sua abrangência e exibindo características que tornam o tema relevante.

O capítulo 2 apresenta uma revisão simplificada acerca do tema central do estudo, que é o transporte marítimo de contêineres e contém algumas informações para contextualização.

O capítulo 3 deste trabalho traz a revisão bibliográfica do tema estudado, apresentando definições e regras encontradas na literatura pesquisada, além de fornecer um resumo de diversas metodologias adotadas para a resolução do problema de logística de contêineres vazios e outros trabalhos que 
apresentam metodologias para a resolução do problema de dimensionamento de contêineres.

O capitulo 4 apresenta algumas características da simulação de eventos discretos e justifica a escolha desta ferramenta para a solução do problema proposto. Neste capítulo, também é apresentado o modelo de simulação construído para este trabalho, através do detalhamento da modelagem construída e das premissas adotadas.

No capitulo 5 são apresentados os resultados obtidos com a aplicação do modelo de simulação, as análises de sensibilidade consideradas relevantes e o comportamento dos estoques de contêineres nos portos de acordo com as situações às quais o sistema é submetido.

Para finalizar, o capítulo 6 apresenta as conclusões tomadas a partir dos resultados obtidos e os comentários finais acerca do tema e do trabalho realizado. 


\section{O TRANSPORTE DE CONTÊINERES, SUAS CARACTERÍSTICAS E A LOGÍSTICA DE CONTÊINERES VAZIOS}

Este capítulo contextualiza o problema estudado e prepara o leitor para um entendimento mais adequado sobre o desafio enfrentado pelas empresas de logística e navegação no que concerne ao planejamento e movimentação dos contêineres vazios e à minimização dos estoques nos terminais.

A partir de uma análise da bibliografia disponível sobre o tema, é feita uma revisão acerca do transporte de contêineres, suas características e também sobre uma das consequências da utilização destes no transporte de mercadorias, o gerenciamento dos contêineres vazios, e outros fatores que tornam o dimensionamento da frota de contêineres, ponto central do estudo, algo de considerável relevância.

\subsection{O CONTÊINER}

Um contêiner pode ser definido como sendo um "tipo de embalagem que acondiciona a carga a ser transportada" (Barco, 1998) e a conteinerização como sendo uma técnica utilizada para o transporte de mercadorias em unidades unitizadas de acomodação dos produtos e que, através de uma modulagem padrão, permitem a manipulação por um sistema integrado entre diferentes modais (rodoviário, ferroviário ou hidroviário).

Ainda de acordo com Barco (1998), a conteinerização gerou uma grande necessidade de se padronizar algumas características (como as dimensões, por exemplo) dos contêineres e dos veículos e equipamentos que os movimentam.

Zambuzi (2010) corrobora com tais definições e cita que o sucesso da utilização dos contêineres no transporte de cargas deve-se, entre outros fatores, a vantagens competitivas como a unitização e modulação oferecidas 
por estes, permitindo uma melhor ocupação dos espaços disponibilizados nos veículos (como os navios e trens, por exemplo) utilizados.

Para a autora, a facilidade obtida com a padronização e a automatização das operações envolvidas na movimentação de cargas conteinerizadas leva ao aumento da eficiência nos pontos de transbordo entre os diferentes modais e nos terminais e depósitos de contêineres, levando à economia de tempo e redução de custos com transporte e armazenagem.

Para que seja possível a padronização e a adequação das operações de armazenamento, movimentação e transporte de contêineres, algumas regras devem ser pré-estabelecidas em âmbito internacional. Sendo assim, foi estabelecida uma unidade conhecida como TEU (do inglês "twenty-equivalent unit" ou unidade equivalente a vinte pés) a partir da qual pode ser medido 0 tamanho de um contêiner e a capacidade de um navio, por exemplo. Tal unidade é baseada nas dimensões de um contêiner padrão, que deve ter 8 pés $(2,4 \mathrm{~m})$ de largura, 8 pés de altura e 20 pés $(6,1 \mathrm{~m})$ de comprimento. Os contêineres mais comuns existentes são os chamados contêineres de 20 pés (1 TEU) e os de 40 pés (2 TEU's).

Zambuzi (2010) relata que a maior parte dos contêineres utilizados seguem as normas definidas pela ISO ("International Standards Organization" ou Organização Internacional de Padronização), entidade que administra normas para mais de 170 países, que define as dimensões de um contêiner como sendo 8 pés de largura, altura entre 8 e 9,5 pés e comprimento de 20 ou 40 pés.

Os tipos de contêiner mais conhecidos são:

- Contêiner padrão de 20 pés;

- Contêiner padrão de 40 pés;

- Contêineres refrigerados (muito utilizados para transporte de produtos perecíveis);

- Contêineres Open Top (possuem abertura no topo);

- Contêineres Flat Rack;

- Contêineres Plataforma;

- Contêineres Tanque (transporte de materiais líquidos e gasosos); 
- Contêineres Ventilados.

Outras vantagens provenientes da utilização de contêineres são citadas por Barco (1998): menor vulnerabilidade das cargas perante avarias e roubos, redução de custos, economia de tempo e facilidades na movimentação de cargas. Porém, o autor destaca uma grande desvantagem, que é a preocupação com a destinação dada aos contêineres, uma vez que surge a necessidade de estocagem dos mesmos e um planejamento adequando do processo logístico para a melhor reutilização dos contêineres vazios.

\subsubsection{O mercado liner}

O mercado de transporte marítimo está estruturado em três modalidades: Liner Operations (ou Liner Shipping), Tramp Shipping e Industrial Operations (RONEN, 2002). O mercado Liner é um tipo de serviço em que os navios transitam em rotas regulares, um itinerário pré-determinado e fixo, com portos e escalas fixas, assim como o cronograma adotado durante um período de planejamento. As cargas transportadas são as cargas gerais, geralmente de alto valor unitário, como veículos, máquinas, entre outros.

O objetivo principal do Liner Shipping é maximizar o lucro por unidade de tempo, e não a minimização de custos (RONEN, 2002). Trata-se de um modo de transporte que trabalha principalmente com a utilização de contêineres, o que permite maior capacidade de transporte, enquanto que navios individuais podem variar em tamanho e capacidade.

As principais diferenças entre o mercado de linhas regulares (Liner) e de linhas não regulares é mostrada na Tabela 2-1. 
Tabela 2-1: Diferenças entre os mercados de linha regular e não regular (Fonte: BNDES)

Linhas Regulares (liner shipping)

Viagens regulares e escalas pré-determinadas

Rotas definidas

Contrato de transporte individualizado por mercadoria

Mercadorias de alto valor agregado

Cargas unitizadas ou conteinerizadas

Estrutura cartelizada

Barreiras à entrada representada por elevados investimentos iniciais
Linhas Não Regulares (chartered shipping)

Viagens não regulares

Rotas não definidas

Contrato de transporte normalmente envolve o

afretamento de toda a embarcação

Mercadorias de menor valor agregado

Cargas soltas (a granel)

Estrutura concorrencial

Facilidade de entrada

Para operar no mercado Liner, são necessários altos investimentos, o que justifica o fato de haver poucas empresas operando no setor.

Até meados da década de 80 , o mercado operava através de conferências de frete fechada, mas na segunda metade da década, iniciou-se um processo de desregulamentação, quebrando o monopólio das conferências, e abrindo espaço para a formação de grandes empresas globais de navegação, pertencentes a países desenvolvidos ou estatais de países em desenvolvimento, como a estatal chinesa Cosco. Apesar de o mercado ser aparentemente aberto, ainda persistem diversas legislações protecionistas por parte de vários países.

Hoje, o mercado Liner contribui significativamente para a economia mundial. Isso se deve a dois motivos principais: o grande montante que esse mercado injeta diretamente na economia global, e o papel que ele exerce como facilitador do crescimento econômico de outros mercados e indústrias.

Em termos de números, em 1980, o mercado de Liner Shipping representava $5,1 \%$ da carga total mundial, enquanto que em 2009, esse valor passou para 24,3\% (UNCTAD, 2010).

Para se ter uma ideia da dimensão do mercado, a frota de navios que atendem o Liner Shipping soma 7.210 navios, divididos em três tipos de navios, como mostra a Tabela 2-2. Observa-se que os navios do tipo porta-contêineres compõem a frota mais expressiva (IHS, 2009). 
Tabela 2-2: Frota Mundial utilizada em liner shipping (Fonte: Lloyd's Register - Jul/2009)

\begin{tabular}{l|r|r}
\multicolumn{1}{c|}{ Tipo de Navio } & Quantidade de Navios & \multicolumn{1}{c}{ DWT } \\
\hline Contêineres & 4.684 & 165.774 .103 \\
Veiculos & 773 & 11.375 .690 \\
Ro-Ro & 1.753 & 7.423 .240 \\
\hline \hline TOTAL & $\mathbf{7 . 2 1 0}$ & $\mathbf{1 8 4 . 5 7 3 . 0 3 3}$ \\
\hline
\end{tabular}

Além da frota já existente (em 2009), mais 1.381 embarcações foram solicitadas e deveriam ser incorporadas a essa frota, como representa a Tabela 2-3.

Tabela 2-3: Tamanho da frota a ser incorporada em serviços de Liner Shipping (Fonte:

Lloyd's Register - Jul/2009)

\begin{tabular}{l|r|r}
\multicolumn{1}{c|}{ Tipo de Navio } & Quantidade de Navios & \multicolumn{1}{c}{ DWT } \\
\hline Contêineres & 1.082 & 63.755 .615 \\
Veiculos & 214 & 3.539 .701 \\
Ro-Ro & 85 & 814.676 \\
\hline \hline TOTAL & $\mathbf{1 . 3 8 1}$ & $\mathbf{6 8 . 1 0 9 . 9 9 2}$ \\
\hline
\end{tabular}

2.1.2. Panorama atual do transporte de contêineres

Na última década, houve um aumento da movimentação de contêineres no Brasil. No entanto, com a crise econômica que ocorreu em 2008, essa tendência de crescimento foi interrompida e observou-se uma redução da movimentação de contêineres, conforme a Tabela 2.4 obtida através da Agência Nacional de Transporte Aquaviário (ANTAQ). 
Tabela 2-4: Evolução anual, por natureza de carga (em toneladas). Fonte: ANTAQ

\begin{tabular}{|r|r|r|r|r|c|}
\hline Ano & Granel Solido & Granel Liquido & Carga Geral & \multicolumn{1}{c|}{ Contêiner } & \multicolumn{1}{c|}{ Total } \\
\hline 2005 & 392.903 .932 & 163.717 .494 & 37.833 .211 & 54.964 .144 & 649.418 .781 \\
\hline 2006 & 415.727 .739 & 175.541 .324 & 38.225 .648 & 63.338 .757 & 692.833 .468 \\
\hline 2007 & 457.435 .373 & 194.598 .576 & 34.760 .346 & 67.922 .360 & 754.716 .655 \\
\hline 2008 & 460.184 .343 & 195.637 .355 & 39.253 .621 & 73.248 .231 & 768.323 .550 \\
\hline 2009 & 432.985 .386 & 197.934 .640 & 36.617 .450 & 65.393 .665 & 732.931 .141 \\
\hline
\end{tabular}

Apesar do crescimento reduzido, comparativamente a 2008, no ano de 2009 o índice de conteinerização subiu para 65,58\%, como mostra a Figura 2-1.

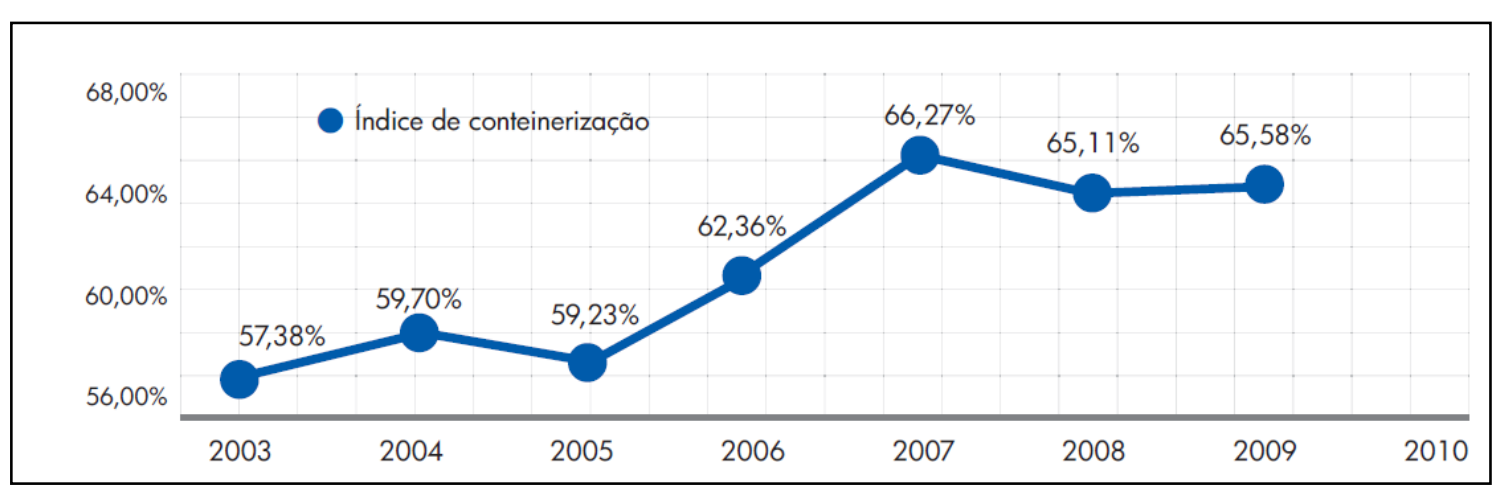

Figura 2-1: Evolução do índice de conteinerização. Fonte: ANTAQ

Um dos motivos pelo qual há essa estabilização após certo crescimento é o fato de que determinadas cargas não se viabilizam transportadas por contêineres, por sua natureza, exigindo operações específicas de carga.

Além da redução da movimentação de contêineres entre os anos de 2008 e 2009, houve também a redução da importação e exportação, em 16,58\% e 7,56\%, de acordo com a ANTAQ (2010). Tal fenômeno pode ser em parte explicado pela crise mundial, e também pela desvalorização cambial (em agosto de 2008, a taxa de câmbio R $\$$ /US\$ estava em 1,6123 ), que tornou os produtos importados mais caros comparados aos produtos nacionais.

No território nacional, a região que mais movimenta contêineres é a sudeste. Em 2009, os portos do sudeste movimentaram 53,1\% da movimentação nacional de contêineres. Além disso, o porto de Santos (SP) continua liderando o ranking dos portos públicos que mais movimentam contêineres, somando 
313.002 unidades no ano de 2009. Em segundo e terceiro lugar se encontram os portos de Santo Francisco do Sul (SC) e o porto de Fortaleza. Alguns dados referentes a terminais públicos são apresentados na Tabela 2-5.

Tabela 2-5: Quantidade de contêineres em cais públicos (Fonte: ANTAQ)

\begin{tabular}{|l|l|r|r|}
\hline \multicolumn{1}{|c|}{ Porto } & \multicolumn{1}{c|}{ Terminal } & \multicolumn{1}{c|}{ 2008 } & \multicolumn{1}{c|}{ 2009 } \\
\hline Santos & Cais Público & 385.833 & 313.002 \\
\hline São Francisco do Sul & Cais Público & 145.040 & 102.862 \\
\hline Fortaleza & Cais Público & 37.947 & 35.208 \\
\hline Belém & Cais Público & 28.767 & 25.477 \\
\hline Suape & Cais Público & 8.492 & 18.443 \\
\hline Vila de Conde & Cais Público & 14.169 & 16.772 \\
\hline Imbituba & Cais Público & 14.660 & 16.069 \\
\hline Paranaguá & Cais Público (Múltiplo Uso) & 7.503 & 9.689 \\
\hline Natal & Cais Público & 9.513 & 8.008 \\
\hline Santarém & Cais Público & 2.952 & 3.163 \\
\hline Maceió & Cais Público & 3.189 & 3.056 \\
\hline Rio Grande & Cais Público & 5.479 & 2.204 \\
\hline Salvador & Cais Público & 4.533 & 648 \\
\hline Itaqui & Cais Público & 493 & 577 \\
\hline Vitória & Cais Público (Capuaba) & 100 & 540 \\
\hline Paranaguá & Cais Público (Corex) & 1.688 & 378 \\
\hline
\end{tabular}

As rotas internacionais de transporte de contêineres são a Leste-Oeste (Transpacífico, Europa-Leste e Transatlântica), Norte-Sul e rotas regionais. A principal delas é a Leste-Oeste, que interliga a Ásia, América do Norte e Europa Ocidental, por onde são transportados cerca de $44 \%$ da carga mundial e utilizados $60 \%$ da frota de porta-contêineres (YAGUIU, 2006). As estimativas do fluxo de carga das principais rotas em 2005 e 2015 são apresentadas na Figura 2-2. 


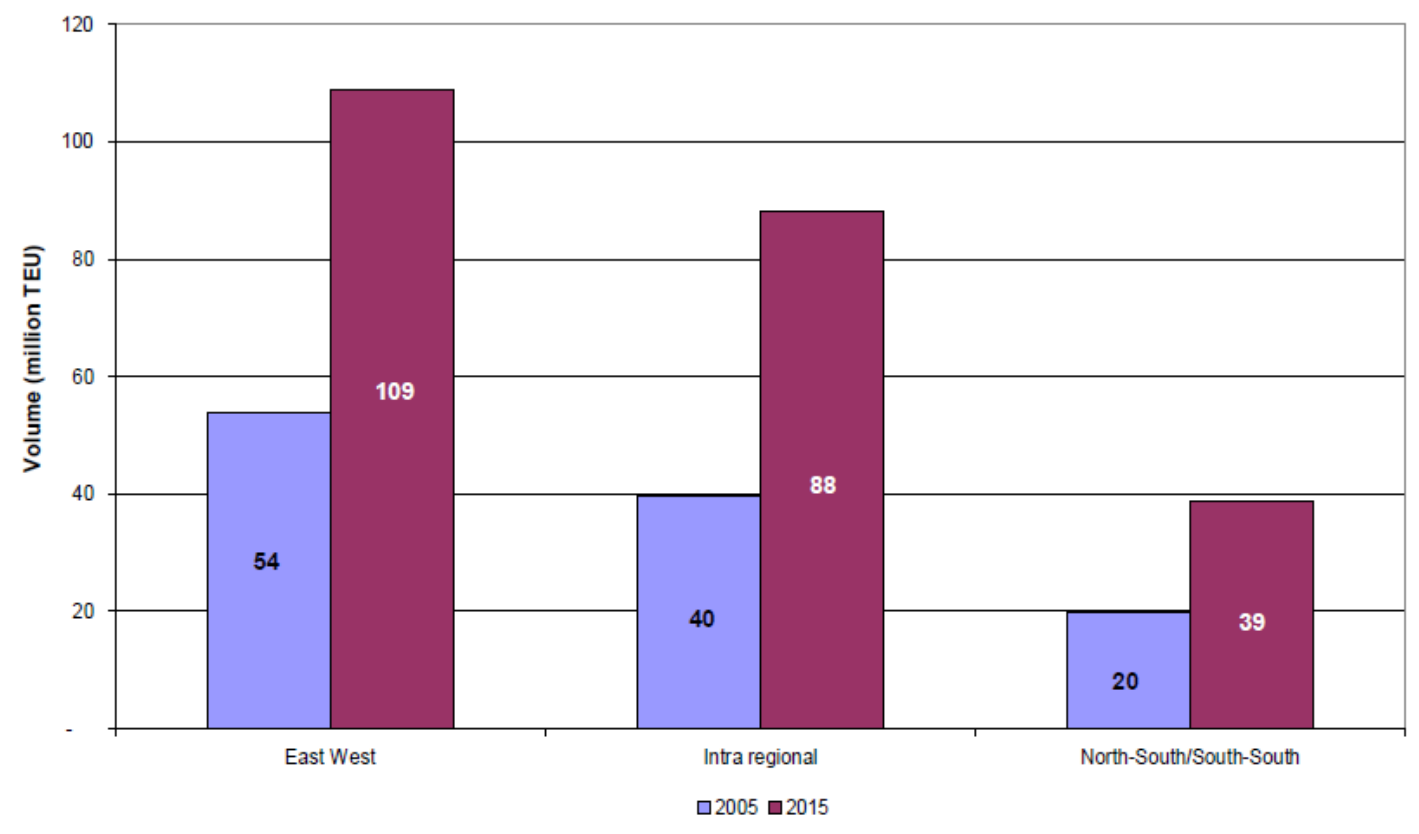

Figura 2-2: Estimativa do fluxo de carga nas principais rotas (Fonte: UNCTAD, 2008)

Globalmente, verifica-se também a tendência geral de conteinerização. Segundo estimativas, desde 1990, o tráfego de contêineres praticamente se quintuplicou. Em função desse aumento, em 2007 a rota Ásia-Europa ultrapassou o Transpacífico, se tornando a mais importante rota de movimentação de contêineres (UNCTAD, 2008). A Figura 2-3 apresenta esse crescimento do comércio global de conteinerizados.

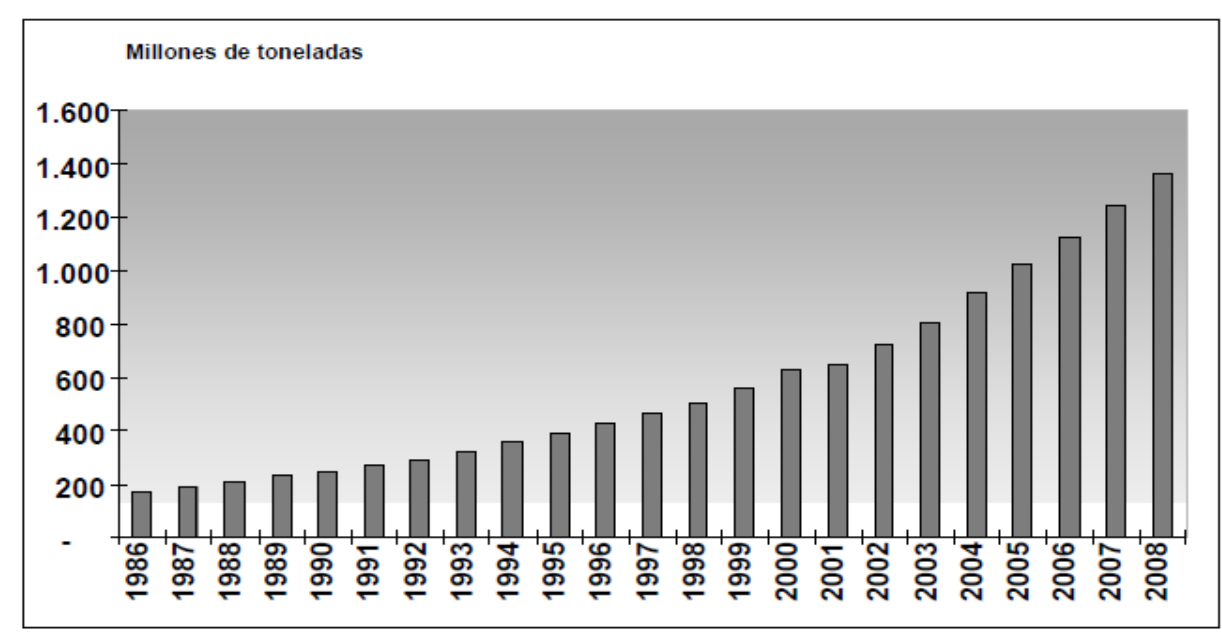

Fuente: Clarkson Research Services, Shipping Review Database, primavera de 2008, pág. 101.

Figura 2-3: Crescimento do comércio internacional de conteinerizados, 1986-2008 (Fonte: UNCTAD) 
Os navios porta-contêineres também têm evoluído ao longo do tempo, ficando maiores, melhores e mais rápidos (MEWIS e KLUG, 2004). A largura e 0 comprimento estão maiores e a capacidade de transporte em TEU's e da capacidade de se produzir motores mais potentes evoluíram, fazendo com que os navios ficassem mais ágeis (NOBRE, 2005). Não só se observa a mudança nas características dos navios, como também a frota também cresceu bastante desde a década de 1990 (UNCTAD, 2010). A Tabela 2-6 mostra as modificações no tamanho da frota e capacidade dos navios.

Tabela 2-6: Evolução da frota de navios porta-contêineres (Fonte: UNCTAD)

\begin{tabular}{|c|c|c|c|c|c|c|c|}
\hline Ano & 1987 & 1997 & 2007 & 2008 & 2009 & 2010 & $\begin{array}{c}\text { Aumento } \\
\text { percentual } \\
\text { (2010/2009) }\end{array}$ \\
\hline Número de Navios & 1.052 & 1.954 & 3.904 & 4.276 & 4.638 & 4.677 & $0,83 \%$ \\
\hline \begin{tabular}{|l} 
Capacidade em TEU's \\
\end{tabular} & 1.215 .215 & 3.089 .682 & 9.436 .377 & 10.760 .173 & 12.142 .444 & 12.824 .648 & $5,32 \%$ \\
\hline Tamanho Médio dos Navios & 1.155 & 1.581 & 2.417 & 2.516 & 2.618 & 2.742 & $4,52 \%$ \\
\hline
\end{tabular}

Tais informações reiteram a afirmação de que as melhorias no transporte de contêineres e nas atividades a ela ligadas (como a logística de contêineres vazios) podem trazer muitos benefícios para a economia global.

\subsection{A LOGÍSTICA DO CONTÊINER VAZIO}

Sendo o contêiner um objeto com certo valor agregado e fabricado a partir de um material durável, é claro e evidente que este deve ser reutilizado inúmeras vezes, retirado e reinserido dentro de diferentes ciclos de transporte. Além disso, os efeitos do chamado "imbalance" decorrente do desequilíbrio entre demanda e oferta de contêineres nos terminais resultam na necessidade de movimentos e alocação de contêineres vazios. Partindo desta abordagem surge aquilo que pode ser chamada de logística dos contêineres vazios, uma vez que os contêineres esvaziados em um destinatário final devem ser remanejados de forma a melhor atender outros clientes e evitar o surgimento 
de novos custos relacionados ao aumento da frota de contêineres ou à necessidade de leasing.

\subsubsection{Imbalance}

O termo "imbalance" é uma palavra da língua inglesa cujo significado é desequilíbrio, desigualdade. No contexto deste estudo, "imbalance" é o termo utilizado para se referir à diferença entre a quantidade de contêineres vazios necessários em um ponto de demanda e o número de contêineres vazios disponíveis nos pontos de oferta.

De acordo com Zambuzi (2010), existe certo desequilíbrio no mercado de contêineres, justificado pela natureza comercial dos locais em que são movimentados estes objetos: enquanto alguns locais possuem características exportadoras, outros possuem características voltadas à importação. Isso gera um desbalanceamento que culmina na movimentação e realocação dos contêineres vazios. Barco (1998) cita que em certos pontos de uma rede considerada, existe uma sobra de contêineres, que precisam ser levados até um ponto onde haja uma demanda, a partir de um movimento que não gera lucros por se tratarem de contêineres vazios.

Para Costa (2006), é muito difícil tratar o problema de "imbalance" em um modelo de auxílio à tomada de decisões em nível operacional devido ao caráter estocástico deste, visto que seria necessário o conhecimento das demandas em cada terminal envolvido no estudo e tais informações possuem incertezas. Segundo o autor, o estudo é simplificado em níveis tático e estratégico, pois, nesses casos, a demanda pode ser considerada conhecida em um horizonte de tempo maior.

De acordo com Song e Dong (2010), o imbalance é fator fundamental para a existência do problema de movimentação dos contêineres vazios. Os autores citam como exemplo o transporte de contêineres pelo Oceano Pacífico, uma vez que o fluxo de mercadorias é maior dos países asiáticos para a América e causam a necessidade de transportar contêineres vazios no sentido oposto. 


\subsubsection{Contêineres vazios}

Os contêineres vazios foram estudados em diversos trabalhos, por diferentes autores. Isso se deve à grande importância e dificuldade que o planejamento relacionado à sua destinação apresenta. Crainic et al. (1993) destacaram em sua pesquisa que um contêiner cheio transportado tem como consequência pelo menos um movimento de contêiner vazio.

De acordo com Di Francesco; Crainic e Zuddas (2009), o processo de reposicionamento de contêineres vazios em um sistema marítimo pode ser definido como o planejamento da distribuição destes contêineres de forma que sejam minimizados os estoques, os custos com transporte e manuseio ao passo que a demanda seja atendida em todos os portos.

Cheung e Chen (1998) definiram um itinerário comumente executado pelos contêineres durante um ciclo logístico. A Figura 2-4 é uma adaptação deste itinerário. Nesta figura, o Porto A representa um porto que envia contêineres para determinado Porto $B$, que somente recebe. Em casos reais, os portos atuam tanto como emissores quanto receptores de contêineres.

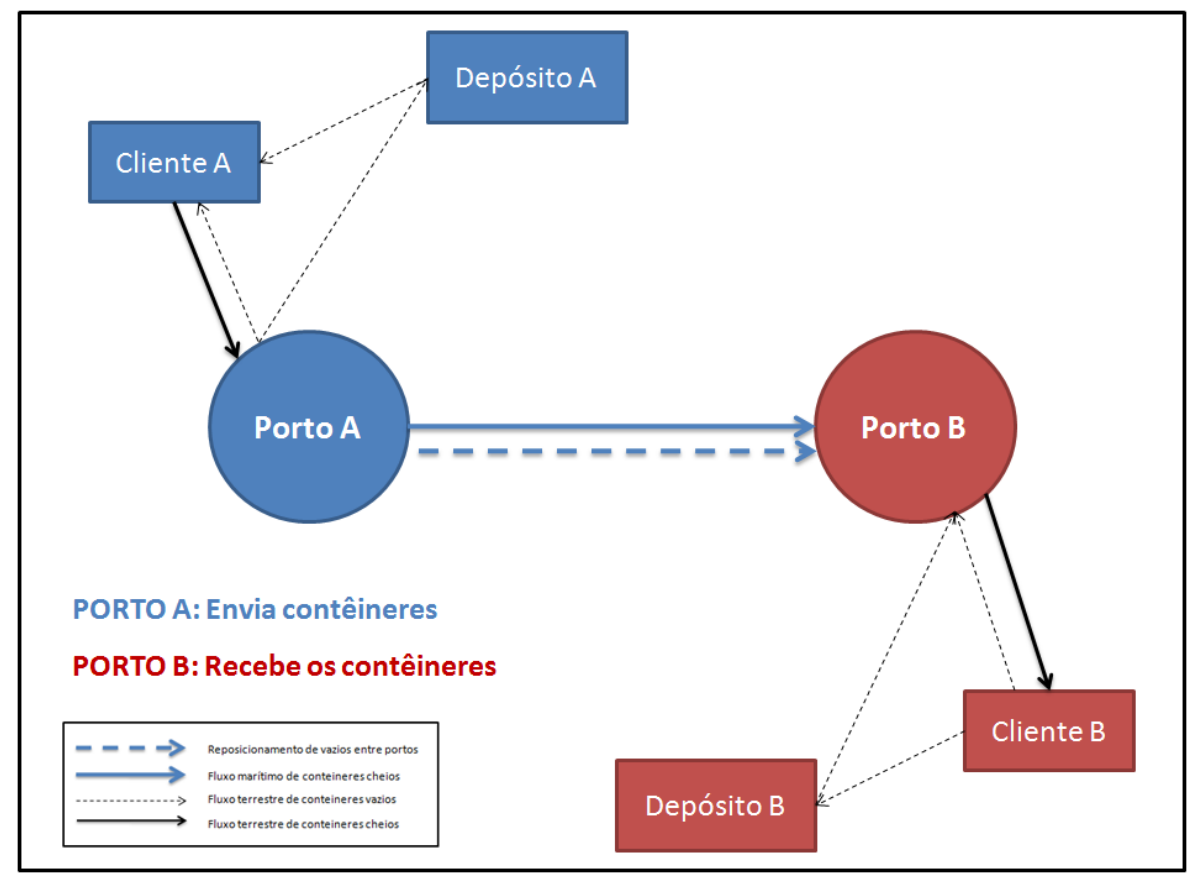

Figura 2-4: Representação gráfica do ciclo logístico dos contêineres (Fonte: o autor) 
O mesmo autor define como contêineres disponíveis em um porto todos os contêineres armazenados, os que estão retornando dos clientes, os contêineres descarregados e os que podem ser alugados e reutilizados. Para Cheung e Chen (1998), os contêineres vazios geram custos quando são carregados e descarregados dos navios, armazenados, transportados e quando são alugados.

Yun; Lee e Choi (2010) afirmam que as empresas costumam perder tempo com reposicionamentos de contêineres vazios e movimentações entre os locais (portos, depósitos, etc.) onde estes são armazenados e citam que um gerenciamento eficiente nesta área pode aumentar a produtividade da empresa. As decisões que uma empresa deve tomar são, basicamente, de que maneira a demanda de contêineres vazios será atendida, qual rota deve ser traçada por um contêiner vazio, como e quando o transporte será realizado. Para que estas decisões sejam tomadas, é necessário que se conheçam os estoques de contêineres vazios em todos os portos e depósitos existentes e se estes podem ser utilizados.

Segundo Barco (1998), o problema de "imbalance" é o principal responsável pelo acúmulo de contêineres vazios em alguns portos e a carência destes em outros. Rezende (2003) corrobora com a ideia e também associa o gerenciamento dos contêineres vazios ao problema de desequilíbrio entre demandas e ofertas de contêineres e afirma que estes vazios geram custos às empresas.

Costa (2006) afirma que o problema da movimentação de contêineres vazios é um problema do tipo estocástico devido ao desconhecimento do número de reposicionamentos e ações que corrijam o imbalance existente.

A grande dificuldade de se tratar o problema dos contêineres vazios é, segundo Barco (1998), a necessidade de se prever a falta destes objetos, uma vez que essa previsão depende de diversos fatores, tais como:

- Fechamento da carga a ser transportada em cada navio;

- Datas de partida dos navios;

- Estoque de contêineres vazios em cada horizonte de tempo;

- Retorno de contêineres em trânsito; 
- Programação de navios.

Tais fatores acabam gerando incerteza nos dados utilizados como entrada de um modelo matemático que aborde a logística do contêiner vazio. Cheung e Chen (1998) afirmam que a disponibilidade de contêineres em um operador do serviço liner está sujeita a uma série de incertezas, incluindo as demandas nos portos, os tempos envolvidos no retorno de um contêiner vazio e a capacidade disponível nos navios para o transporte destes contêineres. Para enfrentar tais incertezas, os armadores costumam atuar com certo conservadorismo.

Devido a isso, o planejamento e gerenciamento de uma frota de contêineres vazios dependem de previsões de ofertas e demandas em todos os portos, o que reafirma a incerteza dos dados e o caráter estocástico do problema. Para Barco (1998), o que torna este tipo de problema complicado são estas incertezas existentes no sistema e a probabilidade de ocorrerem eventos que interfiram no planejamento como, entre outras coisas, erros de previsão, danos em equipamentos, greves e demora na devolução de contêineres.

Tais incertezas levam as empresas a utilizarem um estoque de segurança, evitando que algum frete seja perdido. Essa prática leva ao aumento dos custos, uma vez que surgem gastos com armazenagem, aluguel e amortização de novos contêineres adquiridos. Além disso, um estoque de contêineres vazios excedentes pode ser visto com bons olhos, uma vez que estes podem ficar presos junto aos clientes.

Yun; Lee e Choi (2010) também citam em seu estudo a necessidade de existir uma política de controle de estoque exclusiva para que se mitigue a interferência dos contêineres vazios.

Zambuzi (2010) relata que a distribuição de contêineres vazios é muito comum entre os armadores, que devem optar por alugar contêineres ou transferi-los de um porto para outro para sanar eventuais insuficiências no sistema. $O$ reposicionamento de contêineres vazios leva em consideração dados fornecidos pelo setor comercial da empresa com as prováveis demandas futuras e a programação de cada navio (schedule).

As empresas de navegação devem decidir a quantidade de contêineres vazios carregados e descarregados em determinado porto com antecedência, de 
modo a facilitar o planejamento e a preparação das operações em cada navio. Entretanto, geralmente isso não acontece. Uma prática comum é a interrupção de carregamentos de contêineres vazios, para que o tempo em que o navio ficará atracado seja diminuído, o que leva à falta de equipamentos em outros portos, gerando custos de armazenagem desnecessários. Tal ação é conhecida como "cut-and-run".

Para que os contêineres vazios sejam reposicionados nos navios, estes devem disponibilizar espaços (slots vagos), o que obriga o planejamento a considerar também estes espaços de forma que não haja ocupação em lugares que deveriam abrigar contêineres carregados. Existe ainda uma tática comum entre os armadores: substituir contêineres de 20 pés por outro de 40 pés, mesmo que sobre espaço vazio no contêiner na viagem de ida, pensando em alocar o contêiner em outra viagem na qual o porto de destino se torna um porto de origem.

Segundo Di Francesco; Crainic e Zuddas (2009), é comum que haja, em grandes portos, áreas especificas para 0 armazenamento de contêineres vazios, que podem ser mantidos, por um preço pré-estipulado, pelo tempo que a empresa de navegação proprietária julgar necessário. Muitas empresas optam por armazenar seus contêineres vazios em depósitos fora da zona portuária por estes oferecerem tarifas de estocagem mais em conta que aquelas geralmente utilizadas pelas companhias portuárias. Segundo os autores, portos pequenos não possuem áreas dedicadas à estocagem de contêineres, o que acarreta em maior tempo utilizado para o transporte destes.

Barco (1998) define dois tipos de aluguel de contêineres: leasing, que é o aluguel em empresas especializadas nesta atividade e subleasing que é a utilização de contêineres de outro armador. Comumente as empresas firmam contratos longos para o aluguel de contêineres, incorporando muitos destes às sua frota com a opção de devoluções periódicas, flexibilizando as operações. Segundo Rezende (2003), não existe um valor fixo para as taxas diárias de aluguel de contêineres vazios em operações de leasing. A autora diz que o valor per diem pago pelas empresas de navegação que alugam contêineres varia de acordo com diversos fatores, entre eles quantidade e prazo considerados. 
Por outro lado, Zambuzi (2010) define três tipos de operações com os contêineres vazios: frota própria armazenada, aluguel de curto prazo e aluguel de longo prazo.

Song e Dong (2010) apud The ROI Container Cargo Alliance (2002) afirmam que o reposicionamento de contêineres vazios se tornou um dos principais desafios enfrentados pelas empresas de navegação e que, desde 1993, cerca de $20 \%$ de todos os movimentos de contêiner pelos oceanos foram realizados com estes vazios. 


\section{REVISÃO DA BIBLIOGRAFIA}

Existe uma grande quantidade de trabalhos acadêmicos cujo tema central é o transporte de contêineres. Estes trabalhos e pesquisas consideram, entre outros assuntos, a movimentação destes recipientes, a logística dos vazios e o dimensionamento de frotas de contêineres.

Dentre os trabalhos analisados, observa-se a utilização de muitas técnicas consagradas na busca de soluções ótimas e que representam menores custos ou margens satisfatórias às empresas de navegação, como a otimização através de programação linear e utilização de heurísticas. Também são encontrados estudos que utilizam técnicas de simulação por eventos discretos.

Apresenta-se, então, uma revisão de trabalhos que tratam o problema de reposicionamento de vazios e o dimensionamento da frota de contêineres. Esta revisão bibliográfica é considerada de suma importância para entendimento do problema central e encaminhamento da abordagem e premissas utilizadas na sua resolução.

\subsection{REVISÃO DE METODOLOGIAS - DIMENSIONAMENTO DA FROTA DE CONTÊINERES}

Como visto nos capítulos anteriores, este trabalho propõe um modelo de simulação capaz de auxiliar no dimensionamento da frota de contêineres cheios e vazios que devem estar disponíveis nos portos de determinada rota.

De acordo com Imai e Rivera (2001), dimensionar a frota de contêineres é um modo de determinar as quantidades necessárias para atender às demandas futuras, enquanto que os problemas de administração da frota geram ações como o reposicionamento ou o leasing de vazios. Caso um armador disponha de uma grande frota de contêineres próprios, provavelmente este necessite realizar poucos movimentos com vazios e ou aluguel de recipientes, mostrando interdependência entre decisões estratégicas e operacionais. 
Existem diversos estudos que tratam do dimensionamento de frotas de veículos (caminhões, trens, navios, etc) e do reposicionamento de contêineres vazios. Entretanto, a maioria destes trabalhos não possui abordagens relevantes ao problema do dimensionamento da frota de contêineres e poucos são os trabalhos que abordam diretamente o tema.

Tal observação também é destacada na revisão bibliográfica do estudo realizado por Yaguiu (2006), um dos únicos que trata diretamente da frota de contêineres. A autora afirma, entre outras coisas, que modelos que tratam do dimensionamento de frota de veículos e de contêineres se diferenciam em diversos aspectos, entre eles o tratamento para o arrendamento de contêineres em longo prazo e a aleatoriedade dos tempos de trânsito dos contêineres em terra. Imai e Rivera (2001), por sua vez, desconhecem estudos que abordem o dimensionamento da frota de contêineres.

Para Li et al. (2007), um gerenciamento eficiente do transporte marítimo passa por coordenar a distribuição de bens e materiais entre os fornecedores, indústrias, distribuidoras e clientes através de uma frota de navios. Seu trabalho tem como objetivo determinar uma estratégia de alocação de contêineres em um conjunto de portos e ajustar as ofertas e demandas em todos estes. Os autores descrevem muito bem o efeito do imbalance decorrente da diferença entre demanda e oferta nos diferentes portos e citam que o aluguel de contêineres é uma operação muito utilizada pelas companhias de navegação para que não haja a perda de clientes por falta de capacidade de atendimento.

A ideia proposta por Li et al. (2007) parte de um modelo de determinação de política ótima de estoque para um porto, para uma política que considere mais de um porto, interligados em uma rota. Seu modelo estabelece os limites máximo e mínimo de estoque de contêineres vazios em um porto para que os custos sejam minimizados. Porém, tais níveis de estoque não podem ser considerados os valores ótimos quando se analisa um conjunto de portos, visto que a quantidade ótima de contêineres exportados por um porto pode não ser a mesma quantidade que outro porto necessita importar. Além disso, Li et al. (2007) descobriram que as quantidades mínimas ou máximas de contêineres vazios estocadas em um porto convergem para um mesmo valor caso o outro 
limite da política de estoque seja mantida fixa. Isso possibilitou o desenvolvimento de uma heurística para a determinação da política de estoque que permite redução dos custos.

Em cada porto, caso a quantidade de contêineres que devem ser exportados seja maior que a soma de contêineres vazios disponíveis com o saldo de exportações da última viagem, haverá o aluguel de contêineres vazios para que se atenda totalmente à demanda.

Li et al. (2007) chegam à conclusão de que seu modelo possibilita a análise dos limites de estoque em variados cenários e configurações de rotas, e que a complexidade da política de estoques está presente em qualquer estado do problema.

Lagoudis et al. (2006) destacam trabalhos que abordam o dimensionamento da frota de veículos, roteirização em viagens e reposicionamento de contêineres vazios e também atestam a escassez de estudos que abordam 0 dimensionamento da frota de recipientes. Em seu estudo, Lagoudis et al. (2006) procuram determinar a frota de contêineres que permite o atendimento da demanda nos portos de uma rota do Mediterrâneo e minimize o que eles chamam de "ociosidade" dos contêineres. A formulação proposta por Lagoudis et al. (2006) é dividida em um modelo de dimensionamento da frota e outro de roteirização dos navios entre os portos considerados. Basicamente, pode-se dizer que essa formulação parte da premissa de se considerar equilíbrio entre a quantidade de contêineres cheios carregados e descarregados dos navios em cada porto, equilíbrio esse representado pela equação (3.1).

$$
\sum_{i=1}^{n} C f_{i}^{+}=\sum_{i=1}^{n} C f_{i}^{-}
$$

Onde:

- $\quad i=1,2,3, \ldots, \mathrm{n}$ é o índice que representa os portos

- $\quad \mathrm{Cf}^{+}$: contêineres cheios descarregados aos portos

- $\mathrm{Cf}^{-}$: contêineres cheios carregados nos navios

A partir desta equação (3.1) e de um desenvolvimento matemático que garante o atendimento da demanda. Lagoudis et al. (2006) apresenta uma formulação 
para determinar a quantidade de contêineres necessária. A equação obtida é a equação (3.2).

$$
C^{r}=\sum_{i=1}^{n} C f_{i}^{-} * \operatorname{int}\left(\frac{T R U C_{i}}{T_{i}^{r}}+2\right)+\sum_{j=1}^{m} \Delta C f_{j}^{+} * \operatorname{int}\left(\frac{T R U C_{i}}{T_{j}^{r}}+1\right)
$$

Onde:

- $\quad r$ : índice que representa o serviço de linhas regulares (liner);

- $C^{r}$ : quantidade total de contêineres para atender a demanda;

- TRUC : tempo que um contêiner leva para retornar a um porto $i$ desde que é descarregado;

- $T_{\mathrm{i}}^{\mathrm{r}}$ : intervalo entre duas passagens de um navio em um porto $i$ (ou $j$ ).

Lagoudis et al. (2006) utilizaram a equação (3.2) para determinar a quantidade de contêineres e navios necessários para visitar 7 portos, a uma velocidade de 15 nós para cada navio e transportar determinada quantidade de contêineres (considerando um tipo, apenas) em um ano. Ressalta-se que o modelo proposto é simplificado, utiliza equações do primeiro grau e não considera técnicas de programação linear para apresentar a frota ótima.

Um trabalho considerado de grande relevância para o tema é o estudo desenvolvido por Yaguiu (2006). Em sua dissertação, Yaguiu (2006) propõe o desenvolvimento de um modelo matemático determinístico e de simulação para estimar uma frota otimizada de contêineres próprios ou alugados, considerando as dificuldades de se tomar decisões em um mercado tão desequilibrado como é o que uma empresa de navegação atua. Primeiramente, Yaguiu (2006) descreve o procedimento de Imai e Rivera (2001) para dimensionamento da frota de contêineres.

Imai e Rivera (2001) descrevem três modelos que tratam o problema de dimensionamento da frota de contêineres: um modelo analítico para tratar uma frota de contêineres dry em um mercado balanceado, um modelo analítico que estuda a frota de contêineres refrigerados em um cenário com imbalance e um modelo de simulação. Destaca-se o fato de Imai e Rivera (2001) utilizarem em 
seu estudo cálculos determinísticos e que não consideram aleatoriedade dos parâmetros, além de não utilizar técnicas de programação linear.

Depois de analisar a pesquisa de Imai e Rivera (2001), Yaguiu (2006) decidiu explorar outras linhas de pesquisas e passou a trabalhar no desenvolvimento de um modelo de simulação probabilística, que descreve o comportamento do sistema através de hipóteses ou teorias observadas no problema abordado e auxilia na previsão de comportamentos futuros em função de mudanças realizadas no modo de operação.

A simulação criada por Yaguiu (2006) considera que 3 navios percorrerão uma rota composta por 3 portos a serem visitados e utiliza como dados de entrada a quantidade de contêineres para importação e exportação, a capacidade dos navios, tempos de carregamento e descarregamento, demanda entre os portos, as quantidades exportadas de um determinado porto para os demais existentes e a sequência de portos visitada por cada navio. A Figura 3-1 apresenta a lógica considerada por Yaguiu (2006) para a operação dos navios nos portos.

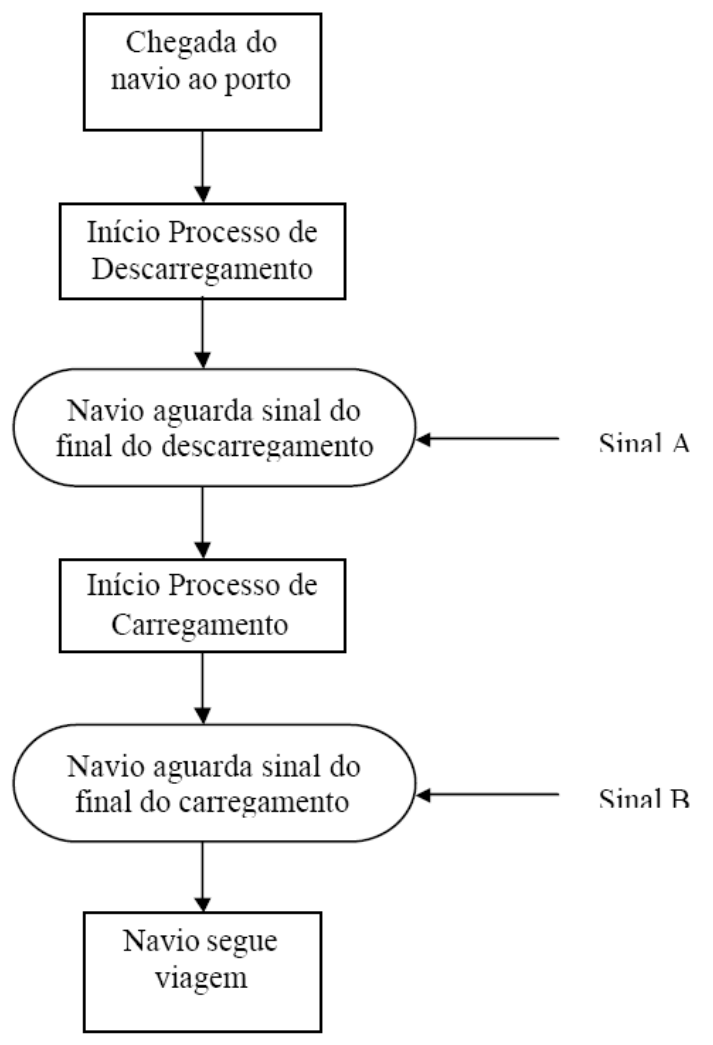

Figura 3-1: Fluxograma da lógica de operação de navios - Yaguiu (2006) 
O modelo de simulação considera os eventos de descarregamento de um contêiner cheio, a necessidade de reparos em cada porto e a limpeza destes recipientes que retornam dos clientes e são armazenados vazios. A lógica de carregamento e descarregamento dos contêineres, que influencia diretamente na lógica de operação dos navios apresentada na Figura 3-1, é apresentada na Figura 3-2. Observe que o "Sinal A" ocorre nessa lógica e avisa ao modelo quando o navio terminou de descarregar os contêineres cheios transportados.

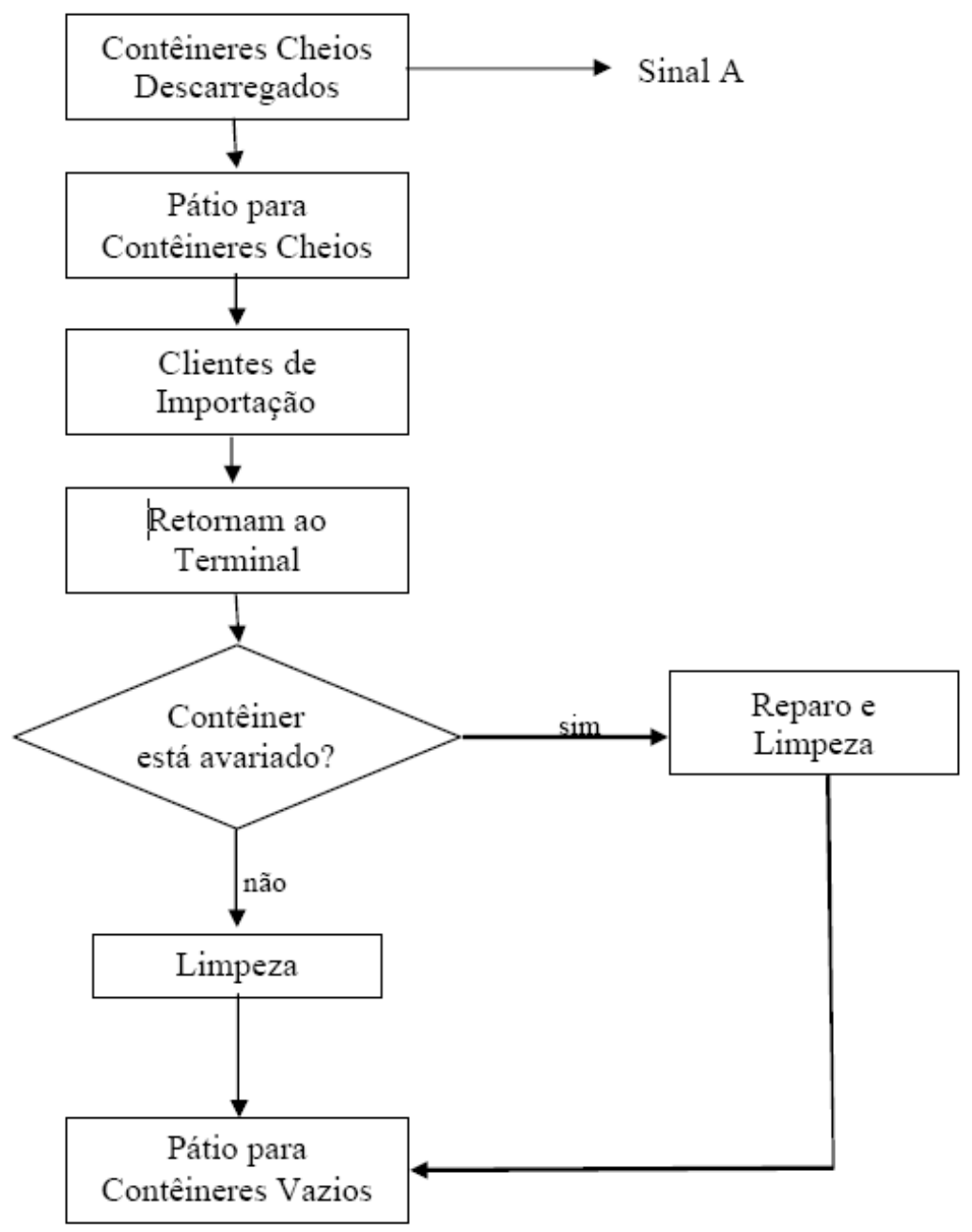

Figura 3-2: Fluxograma da lógica de descarregamento dos contêineres cheios - Yaguiu (2006)

A terceira e última lógica que compõe o modelo de simulação elaborado por Yaguiu (2006) refere-se ao tratamento dado aos contêineres vazios e carregamento destes. Essa modelagem é responsável pelo "Sinal B" 
apresentado na Figura 3-1, ou seja, é a partir de seus eventos que um navio pode ser considerado carregado e seguir viagem. A lógica referente ao processo de manuseio dos contêineres vazios elaborada por Yaguiu (2006) é apresentada na Figura 3-3.

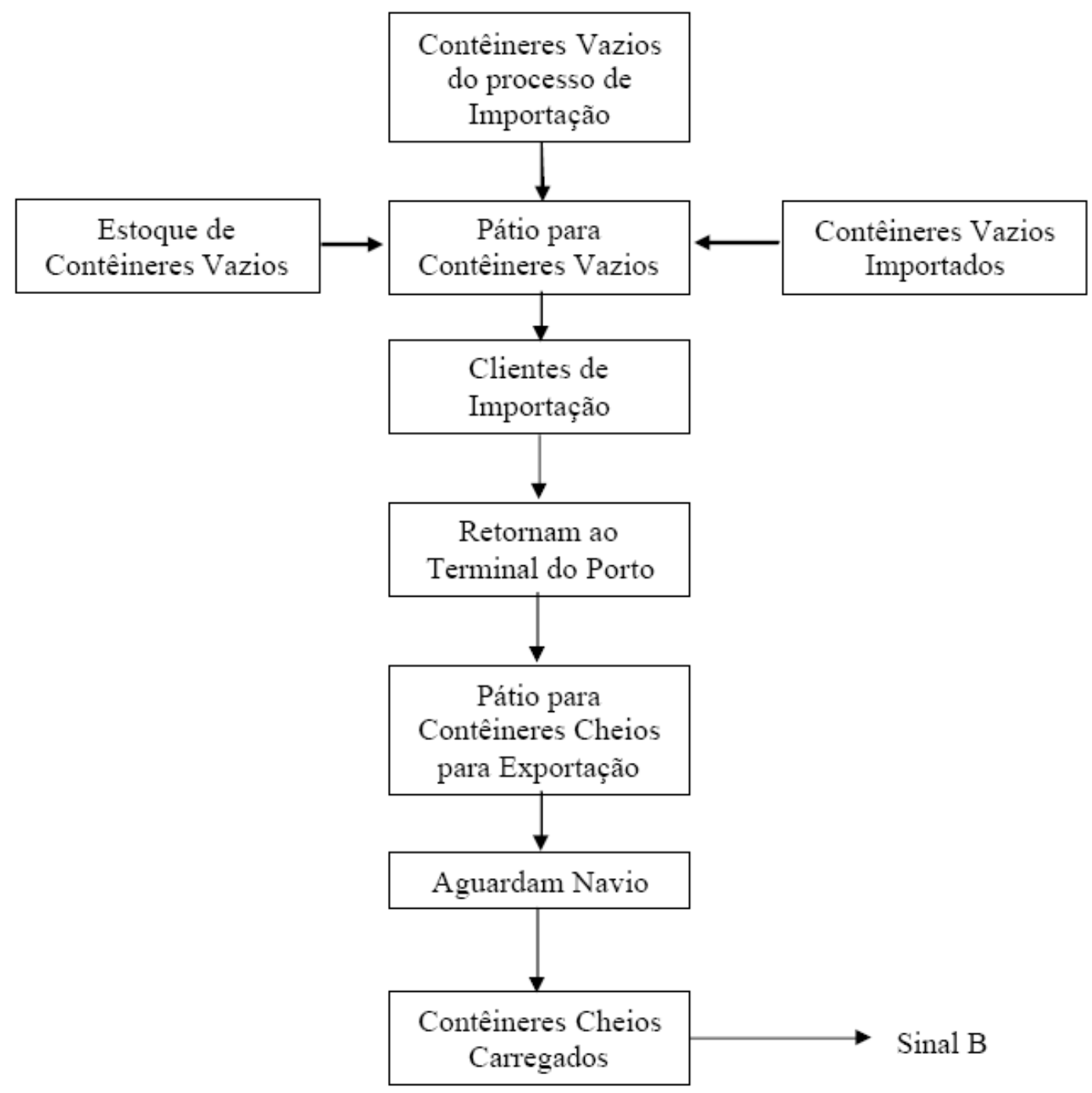

Figura 3-3: Fluxograma da lógica de manuseio dos contêineres vazios - Yaguiu (2006)

O modelo de simulação de Yaguiu (2006) parte de um posicionamento inicial dos navios nos portos da rota e da necessidade de se exportar contêineres vazios apenas se a quantidade exportada em um porto é maior que a quantidade de cheios importada em determinado porto (matriz de cargas utilizada como dado de entrada). 
Processando o modelo diversas vezes, alterando os estoques iniciais de cheios e vazios em cada porto, obteve-se uma configuração que atende à demanda sem que haja exagero na quantidade de contêineres armazenados nos terminais.

De acordo com Yaguiu (2006), seu modelo de simulação apresentou resultados adequados e atendeu às restrições impostas, destacando-se o fato de haver poucas variáveis de controle, o que facilitou a obtenção destes resultados. Yaguiu (2006) afirma que a inclusão de novos portos ao sistema e utilização de outros navios aumentam substancialmente a quantidade destas variáveis de controle, fazendo com que um resultado próximo ao ótimo dificilmente fosse obtido desta maneira. Sendo assim, a solução encontrada foi a construção de um modelo de programação linear que pudesse incorporar a aleatoriedade do sistema, grande facilitador obtido com a simulação, segundo a autora.

A autora elaborou uma formulação completa para o modelo matemático de programação linear, considerando as características dos sistemas marítimo (linhas regulares, segmento liner) e terrestre (trânsito em terra, armazenagem), o manuseio de contêineres vazios e todas as características inerentes ao sistema, como a necessidade de consideração do schedule dos navios e a aleatoriedade dos parâmetros.

O modelo busca obter a solução ótima do custo total do sistema (do ponto de vista da empresa de navegação) através da melhor composição entre contêineres próprios, alugados e reposicionamento de vazios (que pode ser utilizado como grande aliado na busca por estoques mais econômicos).

Yaguiu (2006) adota parâmetros relativos aos custos, às embarcações, às demandas, às capacidades (de navios e estoques) e relativos ao retorno de contêineres vazios, compondo uma extensa lista de parâmetros que, por si só, já reafirma a complexidade do problema e do modelo construído.

É importante destacar o fato de o modelo considerar as passagens dos navios nos portos nos sentidos de ida e volta (norte e sul). Por exemplo, ao invés de haver uma variável de fluxo de contêineres cheios que serão embarcados de um porto $i$ para um porto $j$, em um determinado instante $t$, na viagem de um 
sentido, devem existir duas variáveis diferentes para o transporte entre esses mesmos portos, considerando os dois sentidos.

As variáveis de decisão do modelo se referem ao sistema como um todo, à movimentação de contêineres cheios e vazios, próprios e alugados e às embarcações e considera-se na função objetivo (que é a soma de todos os custos envolvidos: decorrentes das decisões de frotas próprias, referentes ao aluguel de contêineres, referentes ao reposicionamento de vazios, utilizando navios da frota) três situações para garantir que a resolução do problema não dependa de muitas informações do período anterior: os contêineres da frota devem estar embarcados nos navios da frota ou cheios (aguardando embarque nos portos) ou vazios nos terminais da empresa de navegação.

Matematicamente, a função objetivo (custo total) a ser minimizada é composta por quatro diferentes fatores de custo, que são:

- A parcela relativa ao custo da frota própria da empresa;

- A parcela relativa ao aluguel de contêineres;

- A parcela do custo referente ao transporte de contêineres próprios vazios entre dois portos, em qualquer sentido;

- A parcela relativa ao custo associado à estadia dos contêineres cheios nos portos.

Esta função objetivo é descrita na equação (3.3).

$$
\begin{gathered}
C T=\left(\sum_{i \in I} \sum_{j \in J} E P C_{i, j,(t=0)}+\sum_{i \in I} E V_{i,(t=0)}\right) * C P * T \\
+\left(\sum_{i \in I} \sum_{j \in J} \sum_{t \in T}\left(E L S_{i, j, t}\right)+\sum_{i \in I} \sum_{j \in J} \sum_{t \in T}\left(E L N_{i, j, t}\right)\right) *\left(T V_{i, j}+T M C_{i}+T M V_{j}\right) * F_{i, j} \\
+\sum_{i \in I} \sum_{j \in J} \sum_{t \in T}\left(C V_{i, j} *\left(S E S_{i, j, t}+S E N_{i, j, t}\right)\right) \\
+\left(\sum_{i \in I} \sum_{j \in J} \sum_{t \in T}\left(E P C_{i, j, t}\right) * C C C_{i}+\sum_{i \in I} \sum_{j \in J} \sum_{t \in T}\left(E L C_{i, j, t}\right) *\left(F_{i, j}+C C C_{i}\right)\right)
\end{gathered}
$$


Onde:

- $E P C_{i, j, t}$ - quantidade de contêineres próprios cheios no porto $i$, no instante $t$, que será transportado para o porto $j$;

- $E V_{i, t}$ - quantidade de contêineres vazios próprios que irão do porto $i$ ao porto $j$ no instante de tempo $t$;

- $\quad C P$ - custo unitário, diário, dos contêineres próprios;

- $T$ - índice utilizado para indicar o conjunto de todos os períodos de tempo considerados;

- $E L S_{i, j, t}$ - contêineres cheios embarcados no porto $i$, para o porto $j$, em um instante $t$ tal que o navio esteja no sentido sul;

- $E L N_{i, j, t}$ - contêineres cheios embarcados no porto $i$, para o porto $j$, em um instante $t$ tal que o navio esteja no sentido norte;

- $T V_{i, j}$ - tempo de viagem entre os portos $i$ e $j$;

- $T M C_{i}$ - intervalo de tempo médio (a partir da saída do contêiner vazio do depósito de vazios) para que o contêiner cheio chegue ao porto $i$;

- $T M V_{j}$ - intervalo de tempo médio (a partir da chegada do contêiner cheio de importação ao porto l) para que o contêiner vazio chegue ao depósito de vazios;

- $\quad F_{i, j}$ - frete diário para leasing de um contêiner vazio;

- $C V_{i, j}$ - custo de transporte de um vazio próprio entre os portos i e j;

- $S E S_{i, j, t}$ - quantidade de contêineres próprios vazios exportados no porto $i$, para o porto $j$ em um instante $t$ no qual o navio esteja no sentido sul;

- $S E N_{i, j, t}$ - quantidade de contêineres próprios vazios exportados no porto $i$, para o porto $j$ em um instante $t$ no qual o navio esteja no sentido norte;

- $\quad C C C_{i}$ - custo unitário de armazenamento (diário) de um contêiner cheio no porto $i$

- $E L C_{i, j, t}$ - quantidade de contêineres alugados cheios no porto $i$, no instante $t$, que será transportado para o porto $j$.

Complementando o modelo construído por Yaguiu (2006), são utilizadas 15 restrições, que garantem a coerência dos resultados obtidos e a validade desta formulação. As restrições do problema de programação linear são: 
A) Atendimento da Demanda de Exportação dos Portos no sentido sul: deve garantir que a soma de todos os contêineres cheios (próprios e alugados) embarcados no sentido sul seja igual à demanda de exportação para todos os portos;

B) Atendimento da Demanda de Exportação dos Portos no sentido norte: análoga à restrição anterior, porém, referindo-se às viagens no sentido norte;

C) Restrição para o estoque mínimo de contêineres próprios vazios: deve garantir que a quantidade de vazios em estoque não seja menor que o estoque mínimo;

D) Restrição para a saída diária de contêineres vazios para os clientes de exportação: a princípio ilimitada superiormente, é utilizada para fixar um fluxo uniforme de saída diário de contêineres vazios para os clientes, levando em consideração a demanda de exportação nos sentidos norte e sul e a frequência de passagem dos navios;

E) Restrição para a capacidade máxima de leasing de contêineres vazios: restringe a quantidade de alugueis de contêineres a determinado limite para cada porto da rota;

F) Restrição para a capacidade máxima de vazios próprios transportados: deve garantir que a quantidade de vazios transportados a partir de determinado porto não seja maior que a quantidade de vazios que este porto pode disponibilizar;

G) Restrição para determinar a quantidade de contêineres próprios vazios que retornam ao depósito de vazios do porto de índice $i$, no período de tempo $t$, provenientes dos contêineres cheios já embarcados nos navios da frota com destino ao porto de índice $i$ durante o horizonte de planejamento;

H) Restrição para determinar a quantidade de contêineres próprios vazios que retornam ao depósito de vazios do porto de índice $i$ provenientes dos contêineres cheios embarcados nos navios da frota com destino ao porto de índice $i$ durante o horizonte de planejamento;

I) Equilíbrio do estoque de contêineres próprios vazios nos terminais;

J) Equilíbrio do estoque de contêineres próprios cheios nos portos;

K) Equilíbrio do estoque de contêineres cheios alugados nos portos; 
L) Contêineres existentes nos navios no sentido sul na saída do porto de índice $i$;

M) Contêineres existentes nos navios no sentido sul na saída do porto de índice $i$;

N) Capacidade máxima de contêineres dentro das embarcações no sentido sul;

O) Capacidade máxima de contêineres dentro das embarcações no sentido sul.

Yaguiu (2006) utilizou parâmetros de entrada fictícios nas aplicações do modelo. Entretanto, o objetivo principal do estudo, o dimensionamento da frota de contêineres, é considerado alcançado pela autora, que realizou diversos testes, considerando a demanda uniforme ao longo do tempo e demanda variável, e obteve resultados coerentes e soluções com características estratégicas e operacionais, possibilitando o dimensionamento da frota e 0 fluxo de vazios entre os portos bem como a quantidade de alugueis efetuados.

Yun et al. (2010) basearam seu estudo sobre os contêineres vazios no controle de estoque e nas decisões de reposicionamento, aluguel e armazenamento destes. Consideram-se também distribuições estatísticas para se obter a oferta e a demanda e os custos de armazenagem, aluguel e reposicionamento de contêineres vazios.

Para que o problema de controle de estoque dos vazios seja tratado de forma adequada, os autores consideram ainda a sazonalidade na demanda (dois períodos, de alta e baixa demanda), lead-time de reposicionamento constante, lead-time de aluguel nulo, demandas e ofertas semanais independentes entre si (aderentes a uma distribuição probabilística), além de se considerar determinada política de pedidos.

A partir destas premissas, Yun; Lee e Choi (2010) criaram um modelo de simulação através do software ARENA que pudesse auxiliar em um processo de busca para se obter uma política de estoque que minimiza os custos.

A política de estoque é composta por um limite mínimo do estoque $\left(s_{1}\right.$ em períodos de baixa demanda e $s_{2}$ em períodos de alta demanda) e um limite máximo $\left(S_{1}\right.$ em períodos de baixa demanda e $S_{2}$ em períodos de alta 
demanda). Caso o nível de estoque seja menor que $s$, é feito o pedido de contêineres vazios até que este nível alcance o valor $S$. Caso haja a necessidade de se reposicionar contêineres vazios, mas estes não estejam disponíveis, o modelo busca o aluguel destes contêineres, retornando a quantidade de recipientes alugados em determinado período. Como os custos de cada operação estão atrelados ao modelo de simulação, busca-se diminuir o total gasto ao final do período simulado e, para isso, Yun; Lee e Choi (2010) utilizaram uma ferramenta de busca da melhor solução do ARENA $\AA$, chamada OptQuest.

Muitas análises de sensibilidade são possibilitadas pela utilização do modelo, entre elas a variação dos limites de nível de estoque (s e S) e a melhor política de estoque a ser implementada no terminal em questão. Para que fosse obtida a política ótima de estoque, deve-se encontrar os valores de $s_{1}, s_{2}, S_{1}$ e $S_{2}$ que minimizam os custos do terminal. O OptQuest do ARENA® executa as simulações e modifica as chamadas variáveis de decisão de forma iterativa, até que as condições de parada sejam satisfeitas.

Estes trabalhos forneceram uma base muito importante para o modelo proposto nessa dissertação.

\subsection{REVISÃO DE METODOLOGIAS - REPOSICIONAMENTO DE CONTÊINERES VAZIOS}

Uma das estratégias que auxiliam uma empresa de navegação a considerar frotas menores de contêineres próprios é a logística de vazios, mais precisamente $\mathrm{o}$ reposicionamento destes entre portos de uma rota na qual exista desequilíbrio da demanda e o chamado leasing de contêineres (aluguel).

Nesta seção, são apresentadas, de forma resumida, as metodologias que abordam o problema de planejamento da logística de contêineres vazios e que serviram como apoio para a realização deste trabalho.

Um dos pioneiros no estudo de técnicas que possibilitassem a redução de custos através de uma logística de contêineres vazios mais eficiente foi White 
(1972), que tratou o reposicionamento e alocação destes contêineres como um problema clássico de transbordo. Para chegar a uma resolução, o autor adotou um processo de busca por subproblemas, no qual cada um destes também é um problema de transbordo e devem possuir uma solução ótima. Caso contrário, considera-se que o problema principal também não possui uma solução ótima.

White (1972) também considera e destaca o caráter estocástico de alguns parâmetros de entrada do modelo, como muitos outros autores também o fazem, já que dados como o instante de chegada de um navio a um porto não pode ser estimado com absoluta certeza.

Cheung e Chen (1998) denominaram o problema como DCA ("dynamic container allocation" ou problema de alocação dinâmica dos contêineres) e desenvolveram um modelo de redes dinâmico com a função de auxiliar as companhias de navegação a alocar eficientemente suas frotas de contêineres vazios, de modo a diminuir os custos com aluguel e armazenagem destes. $\mathrm{O}$ foco principal da modelagem proposta por Cheung e Chen (1998) é determinar uma rede dinâmica, estocástica, para um tipo único de contêineres, na qual a oferta, a demanda e os espaços disponíveis para transporte nos navios são considerados variáveis aleatórias. Segundo os autores, embora vários modelos tratem do problema, o caráter estocástico e a complexidade de modelagem dificultam a obtenção de soluções eficientes.

Para eles, três importantes variáveis aleatórias compõem o DCA: a demanda nos portos, as ofertas nos portos e as capacidades de transporte restantes nas embarcações. Como os contêineres devem estar com os clientes com certa antecedência em relação à data de embarque, e em varias e diferentes localidades, qualquer atraso na entrega destes pode afetar o planejamento e isso torna a demanda incerta. Além disso, a oferta por contêineres vazios depende dos prazos com que os clientes devolvem os mesmos, outro fator de incerteza para o planejamento. Finalmente, outro fator de aleatoriedade é gerado pela capacidade dos navios, visto que muitas vezes o peso dos contêineres carregados acaba por influenciar a quantidade de carga que pode ser transportada e tal valor pode variar muito, de acordo com o produto que é transportado. 
Cheung e Chen (1998) adotam algumas premissas para sua modelagem, entre elas a consideração de apenas um tipo de contêiner, a impossibilidade de postergar 0 atendimento da demanda para o período seguinte, a possibilidade de se alugar contêineres ilimitadamente (alugueis de longo prazo são considerados frota própria) e a realização de viagens e planejamento fixos. Sua modelagem considera os custos de carregamento, descarregamento, armazenagem e aluguel de contêineres vazios, além do transporte destes e o objetivo principal dos autores é minimizar tais custos impondo restrições como o atendimento da demanda, o balanço de massa e os limites de capacidades dos navios e portos considerados. Cheung e Chen (1998) construíram uma rede cujos nós representam os diferentes portos ao longo do tempo e os arcos de capacidade são as demandas de contêineres transportadas. O arco é dividido em dois estágios: no primeiro estagio, todos os parâmetros são determinísticos e, no segundo estagio, alguns parâmetros são estocásticos. As decisões tomadas pelo modelo incluem a reposição de contêineres e, quantos e quando, contêineres vazios devem ser alugados.

Para resolução do problema, Cheung e Chen (1998) apresentam métodos de linearização estocástica e um procedimento de aproximação estocástica. A partir da obtenção de resultados, os autores comparam o modelo estocástico de dois estágios com uma versão simplificada, determinística, e verificam uma melhor aderência dos resultados obtidos com a versão estocástica. Outra linha de investigação abordada verifica quão apropriada é a utilização do modelo de dois estágios para o problema. Os resultados obtidos podem ser considerados satisfatórios e reafirmam a grande importância de se planejar adequadamente a reposição e o aluguel de contêineres vazios.

Barco (1998) foi um dos primeiros autores brasileiros a considerarem a logística do contêiner vazio no país. Seu trabalho aborda as principais características do problema e considera a previsão de estoque para propor um modelo de programação linear que auxilie as empresas na tomada de decisões em relação à sua frota de contêineres. $O$ autor mostra, antes de qualquer coisa, a grande importância de se ter um sistema eficiente de informações, permitindo a identificação dos pontos de oferta e demanda e possibilitando a 
utilização de métodos de previsão de estoque. Barco (1998) destaca também a importância de se atender à demanda de contêineres

Segundo Barco (1998) é muito importante que se considerem estoques de segurança dos contêineres vazios para compensar as aleatoriedades e incertezas inerentes ao processo, como quebras de equipamentos portuários, greves de trabalhadores, demoras na devolução de recipientes, entre outros. Para se chegar à melhor opção acerca das decisões tomadas em relação aos contêineres vazios, Barco (1998) propõe um modelo de programação linear (considerando somente o caso determinístico) que deve considerar as previsões de demanda realizadas, reafirmando a importância de se adotar técnicas eficientes de previsão e obtendo uma técnica que possibilite a minimização efetiva dos custos.

Uma das particularidades do modelo construído por Barco (1998) é o fato de não se considerarem os períodos de tempo e sim a passagem dos navios nos portos. O horizonte de planejamento considera quais os navios que entrarão na programação (consideraram-se 4 semanas). Barco (1998) considera também vários tipos de contêineres, não utilizando a premissa de substituição vista em outros trabalhos revisados.

Em sua modelagem, Barco (1998) também não deixa de considerar os estoques de segurança nos portos, necessários para compensar fatores externos como necessidade de reparos e aumentos repentinos da demanda.

A solução original do problema proposto por Barco (1998) mostra-se eficiente, pois minimiza o custo das operações garantindo que não haverá falta de contêineres vazios nos portos considerados. A partir da solução original, Barco (1998) realizou alguns testes e análises de sensibilidade para verificar o comportamento do sistema. Entre outros testes, verificou-se a influência do custo de reposicionamento de contêineres por caminhões entre os portos e a imposição de restrições de transporte de vazios nos navios. Para Barco (1998), o modelo construído é operacional o bastante para ser utilizado no planejamento dos reposicionamentos de contêineres vazios pelas empresas de navegação. 
Rezende (2003) dá continuidade ao estudo de Barco (1998), partindo do problema e da modelagem por este proposto e aperfeiçoando o modelo original através da consideração de passagens duplas dos navios pelos portos, utilização da capacidade real dos navios considerados na modelagem e a consideração de um período de antecedência na chegada de um contêiner ao porto, em relação ao embarque do mesmo.

A autora considera uma frota de navios porta-contêineres operando em uma rota Europa (América do Norte) - América do Sul, e o reposicionamento de contêineres entre os portos podem ocorrer através dos espaços vazios destes navios ou ainda por caminhões, além do aluguel de contêineres vazios. Como a modelagem considera a passagem dupla dos navios nos portos, Rezende (2003) adota variáveis de decisão de reposicionamento de um porto para outro considerando o dia. Isso faz com que a autora tenha um cuidado especial em determinar o horizonte de planejamento, visto que o problema pode conter um número muito grande de variáveis.

O modelo proposto por Rezende (2003) também tem como função objetivo a minimização dos custos, respeitando o espaço disponível para o transporte dos contêineres vazios, o estoque mínimo em todos os portos e mantendo-se o balanço de massa dentro do sistema. Rezende (2003) utiliza sua modelagem para testar os dados de entrada utilizados por Barco (1998) e constata a operacionalidade do modelo proposto (não há comparações entre os resultados, pois apesar de ambos representarem o mesmo sistema, o fazem de forma diferente). Também realiza algumas variações em dados de entrada como o custo de armazenagem ou de transportar contêineres vazios e resolve o problema com dados atualizados.

Rezende (2003) cita a complexidade do modelo e o tamanho da codificação do mesmo como sendo as principais desvantagens apresentadas. Também relata que o ideal seria considerar a variabilidade de alguns dados, mas que isso ampliaria o nível de complexidade da formulação.

Shintani et al. (2005) relatam a dificuldade de planejar uma rede de transporte de contêineres (liner) ao mesmo tempo em que se considera a importância do reposicionamento de vazios. Afirmando a importância que o mercado liner obteve no cenário do comércio internacional nos últimos anos, os autores 
destacam a quantidade significativa de movimentos com contêineres e veículos vazios causados pelos desbalanços entre os fluxos de oferta e demanda e o fato de que falhas no planejamento de alocação de contêineres podem gerar a perda de carga ou obrigar a empresa a alugar os recipientes.

De acordo com o problema levantado por Shintani et al. (2005), o gerenciamento do transporte de contêineres pode ser subdividido em planejamento da rota para transporte dos contêineres carregados e administração do reposicionamento (ou aluguel) de contêineres vazios. A proposta dos autores é apresentar um modelo de roteirização de portacontêineres que já considere o reposicionamento de contêineres vazios, de forma a otimizar o problema e reduzir os custos envolvidos. A resolução parte de uma heurística baseada no algoritmo genético.

Shintani et al.(2005) relatam que as empresas de liner prestam serviços regulares, com rotas e planejamento fixos, nos quais as viagens são determinadas por fatores como sazonalidade, exigências de mercado, políticas de favorecimento a determinados clientes, etc. Sendo assim, a companhia de navegação utiliza ferramentas de previsão de demanda para construir as rotas para um horizonte de tempo pré-determinado. Uma prática muito comum é determinar dois portos, um de origem e um de destino, e fixar os portos visitados entre a saída da origem e a chegada ao destino. Com o intuito de maximizar os lucros, as empresas devem determinar quais os portos visitados e a ordem com que isso ocorrerá e, assim, o problema se torna um problema de roteirização. Em algumas viagens, os portos visitados na ida podem não ser visitados no retorno ou vice-versa, atribuindo flexibilidade às rotas determinadas.

Assume-se, para a modelagem, que a demanda por contêineres vazios em um porto em determinado instante é igual à diferença entre os contêineres que deixaram o porto e os contêineres que nele foram descarregados. Outra premissa adotada é a de que toda a carga carregada em um porto atenderá outros portos desde que estejam na mesma rota.

A modelagem considera também o aluguel de contêineres, partindo da premissa de que sempre haverá contêineres disponíveis para o aluguel. Shintani et al. (2005) também impõe que a soma dos contêineres cheios com 
os contêineres vazios não poder ultrapassar a capacidade de transporte dos navios.

A resolução do problema proposto é realizada através da formulação do problema da mochila (Knapsack), subdividindo o problema em dois e buscando a rota considerada ótima para os navios, que maximize a receita ao mesmo tempo em que considera os custos de navegação e o transporte de contêineres vazios. Para calcular o lucro a ser maximizada, Shintani et al. (2005) a dividiram em receitas e em custos, relacionados à manutenção do navio, taxas portuários, valor de combustível, etc. Os autores utilizaram uma heurística que possibilitou a busca da melhor solução do problema através do algoritmo genético e resolveram os dois subproblemas simultaneamente.

Baseados em seus experimentos, Shintani et al. (2005) concluíram que a alocação eficiente dos contêineres vazios diminui, entre outras coisas, o tempo gasto com o manuseio destes contêineres, possibilita a redução da velocidade de cruzeiro dos navios (redução do consumo de combustível) e faz com que diminua a ocorrência de perda de demanda atendida, fator importantíssimo frente à concorrência acentuada existente entre as companhias de navegação.

Olivo et al. (2005) propõem uma abordagem em programação matemática para tratar o problema de gerenciamento dos contêineres vazios. Para os autores, a facilidade decorrente da conteinerização de cargas transformou o transporte de mercadorias porto-a-porto em um transporte porta-a-porta, no qual as empresas transportam as mercadorias desde os fornecedores até 0 destinatário final. Tal efeito alavancou a utilização do contêiner e fez com que certos desafios surgissem, como por exemplo, a utilização eficiente dos contêineres vazios.

O objetivo dos autores é propor um modelo matemático para configurar eficientemente 0 gerenciamento dos contêineres vazios em uma rede multimodal dinâmica e determinística e verificar a implementação desta modelagem através de algoritmos eficientes.

Olivo et al. (2005) atribuem grande importância ao horizonte de planejamento considerado nas modelagens existentes. Para eles, 0 fato de 0 desenvolvimento tecnológico e da comunicação possibilitarem a transmissão 
instantânea de informações sobre a situação das cargas e contêineres entre os diferentes agentes envolvidos no processo faz com que o gerenciamento possa ser realizado para horizontes menores de planejamento, atribuindo maior flexibilidade e eficiência às operações. De acordo com os autores, horizontes menores de planejamento provavelmente não foram adotados anteriormente devido à dificuldade de se tratar tal modelagem computacionalmente, mas tal inovação pode representar uma evolução nos sistemas de transportes e permitir que os tomadores de decisão possam corrigir eventuais falhas em suas operações quase que instantaneamente. Um modelo que considera a discretização do tempo em intervalos de uma hora, por exemplo, possibilita que os serviços de reposicionamento de contêineres possam ser feitos no mesmo dia.

Para que seja conhecida a demanda a cada hora nos locais determinados, devem-se conhecer as demandas de cada cliente e se levar em consideração os tempos de deslocamento. A demanda pode ser modificada caso a necessidade dos clientes seja alterada e o modelo faz uma re-análise para considerar tais mudanças. Outros fatores que afetam 0 tempo de deslocamento, como ocupação dos portos e congestionamento também geram modificações dos dados de entrada do modelo e fazem com que haja um reprocessamento das informações.

A formulação construída por Olivo et al. (2005) considera arcos que representam o deslocamento da frota de navios e de contêineres através do tempo (diferentes nós para representar os mesmos portos ou conjunto de portos em diferentes instantes) e do espaço, possibilitando a modelagem do problema através da programação linear e viabilizando sua resolução.

Olivo et al. (2005) concluem que seu modelo possibilita a aplicação em temporeal devido à escolha pelos instantes considerados a cada hora, permitindo um maior detalhamento dos sistemas de transporte. A representação do problema em arcos que se estendem através dos diferentes períodos, embora descrito como um método que garante a viabilidade do problema de programação linear, permite que os tomadores de decisão possam guiar suas opções através dos resultados obtidos, otimizando o gerenciamento de sua frota e de seus contêineres. 
Bandeira (2005) apresenta um modelo que utiliza pesquisa operacional e heurísticas para a determinação dinâmica dos fluxos de carga. Segundo a autora, o problema de movimentação de vazios é muito complexo por envolver, também, alocação dinâmica dos contêineres para os locais onde ocorre a exportação de mercadorias. Considerar os fluxos normais e de retorno simultaneamente faz com o que o problema considerado tenha natureza combinatória e seja de difícil resolução.

Em sua revisão bibliográfica, Bandeira (2005) cita a importância e o impacto exercido pelo horizonte de planejamento escolhido: horizontes maiores tendem a ser mais adequados por considerar possíveis intervalos mais ativos, além de possibilitar a utilização de tempos de trânsito mais longos, ao passo que pode resultar em maior complexidade computacional e matemática. Para a autora, outro obstáculo enfrentado em seu estudo foi a necessidade de se prever demandas futuras, o que acaba por obrigar as companhias de navegação a executar um bom planejamento em terra e de realocação.

No estudo realizado por Bandeira (2005), dois modelos são construídos inicialmente: um modelo de transbordo para representar a movimentação de contêineres (vazios e cheios) e um modelo de alocação para distribuir da melhor maneira possível os contêineres vazios do sistema. O modelo de movimentação de contêineres vazios tem como função objetivo minimizar os custos das operações considerando o transporte, 0 manuseio e a armazenagem em todos os nós da rede formada por portos, depósitos em terra e um conjunto de clientes de suprimento e demanda. Já o modelo de alocação dos contêineres cheios tem como objetivo transportá-los até o destino final estipulado, buscando sempre obter o menor custo. Criados os dois modelos, estes são integrados para que se obtenha o que a autora chama de modelo integrado, que considera os fluxos de carga normal e reverso.

Bandeira (2005) divide o modelo integrado em estágios, verificando em um instante $t$ as demandas por contêineres cheios, conferindo a disponibilidade de contêineres vazios nos pontos de oferta e realocando estes se necessário. Para a obtenção de soluções preliminares que auxiliem na resolução do modelo integrado, Bandeira (2005) utilizou técnicas de heurística (a autora afirma não ter convicção de que existam técnicas mais eficientes, mas dentre 
os métodos testados, foi escolhida a que apresentou melhores resultados), em função da grande quantidade de combinações existentes. Muitas das técnicas encontradas na literatura revista acabam por integrar o modelo, que utiliza parâmetros determinísticos e estocásticos para suprir a demanda.

A resolução divide os eventos em cada instante adotado e segue uma sequência de atividades para todos estes instantes. A sequência adotada por Bandeira (2005) é apresentada na Figura 3-4.

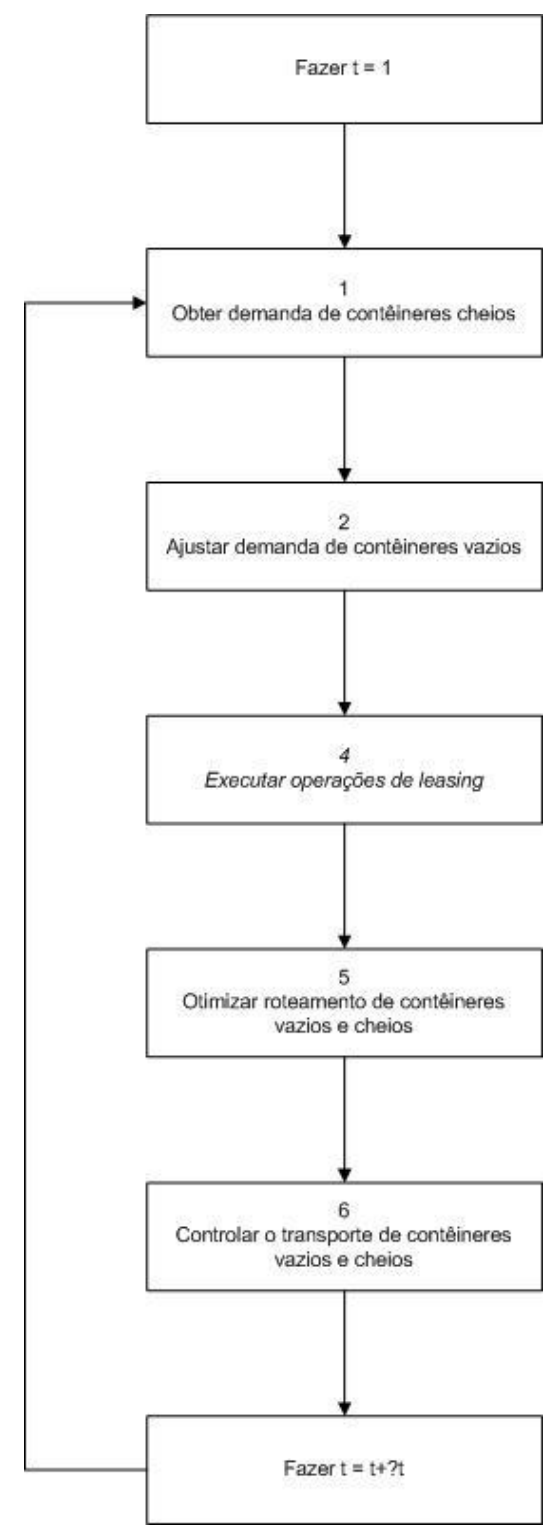

Figura 3-4: Sequência de atividades realizadas pelo modelo desenvolvido por Bandeira (2005) (Fonte: Bandeira (2005)) 
Todos os módulos apresentados no fluxograma da Figura 3-4 são implementados computacionalmente para a resolução do problema proposto. Além disso, a autora construiu um modelo totalmente flexível, a partir do qual muitas análises de sensibilidade podem ser efetuadas, como a alteração do estoque mínimo de contêineres vazios, os tempos médios de transporte, as capacidades de estoque, entre outras.

Os resultados são obtidos, com o modelo de simulação implementado e testado, através de dados de entrada gerados aleatoriamente com base em parâmetros fixos. Bandeira (2005) ainda realizou testes para verificar o comportamento do sistema em função de quantidades de clientes, demandas, ofertas, estoques iniciais, quantidade de depósitos, tempos de armazenagem, processamento e transporte. Pode-se notar, entre outras coisas, que o estoque de contêineres vazios nos portos tende a um valor estacionário conforme as unidades de tempo utilizadas se passam.

Bandeira (2005) acredita que uma das maiores contribuições de seu modelo foi a minimização da ociosidade no sistema já que, ao se verificar com antecedência a necessidade de contêineres vazios, se evitam movimentos desnecessários e diminui os custos da realocação de contêineres vazios.

O estudo de Costa (2006) considera um horizonte de planejamento de um ano para navios que operam em uma rota entre o Brasil e a Europa. Segundo o autor relata em sua revisão bibliográfica, horizontes de tempo mais longos possibilitam gerenciamento mais adequado do transporte de contêineres vazios, até pela possibilidade de analisar o efeito de se utilizar meios de transportes mais lentos e menos dispendiosos. Por outro lado, o horizonte de tempo acaba por não ser determinante caso haja um numero suficiente de terminais na rede considerada. Costa (2006) chama a atenção ao fato de que minimizar os custos nem sempre geram maior lucratividade para a empresa de navegação, visto que isso pode impedir aumentos na receita que compensariam custos maiores.

O modelo proposto no estudo de Costa (2006) explora o problema da seleção de cargas no planejamento de um armador, com o objetivo de maximizar a margem de lucros da empresa. Os parâmetros de entrada do modelo são as características das rotas, a frota de navios considerada, a demanda de cargas 
e as características da logística de contêineres vazios. Como outros autores estudados, Costa (2006) também desenvolveu seu modelo no software chamado GAMS.

Os principais indicadores de nível de serviço oferecidos pelo modelo e que servem como critério de comparação entre cenários analisados são a margem bruta de contribuição, a receita total, o custo total de movimentação de contêineres (cheios e vazios), o custo de armazenagem de contêineres vazios e os custos de atendimento dos tipos de carga. Para que se analise o modelo a partir das operações logísticas de contêineres vazios, pode-se verificar a participação dos contêineres vazios na receita da empresa, a produtividade (relação entre a quantidade de contêineres cheios em um horizonte de tempo e a quantidade de contêineres vazios), o índice de reposicionamento, o índice de estoque e o índice de utilização da frota.

Depois de realizar diversas análises com seu modelo, Costa (2006) comprova a robustez do mesmo, destacando o fato de os resultados obtidos apresentarem consistência e representatividade. Isso, segundo o autor, satisfaz a necessidade proposta de se apresentar uma ferramenta útil à tomada de decisões pelas empresas de navegação.

Costa (2006) conclui que seu modelo demonstra a necessidade constante de planejamento operacional da logística de contêineres vazios e que as empresas de navegação devem sempre se atentar à disputa criada entre os fluxos de contêineres vazios e cheios. Os resultados obtidos comprovam a forte relação que existe entre os resultados obtidos pela atividade comercial da empresa e a logística de contêineres vazios e isso faz com que cada alteração comercial nas operações da companhia de navegação resulte na necessidade de "replanejamento" da logística de vazios.

Também denominando o problema estudado de DCA ("dynamics container allocation" - controle dinâmico de alocação), como Cheung e Chen (1998), Lam; Lee e Tang (2007) apresentam algumas peculiaridades dos modelos estocásticos e determinísticos construídos para tratar o problema de alocação dos contêineres. Para os autores, os modelos determinísticos oferecem maior facilidade para tornar características complexas em problemas tratáveis. Porém, embora os modelos determinísticos possuam suas vantagens, eles não 
consideram as características estocásticas de oferta ou da demanda, o que se torna um ponto a favor dos modelos estocásticos e da simulação. Geralmente, as características estocásticas contêm informações que, se desconsideradas, podem levar a soluções não ótimas para o DCA.

Lam et al. (2007) formularam o problema de alocação de contêineres através de um programa estocástico dinâmico que considera a decisão de estoque ótimo para um custo médio em um horizonte infinito. Uma simulação baseada em um algoritmo iterativo é a ferramenta utilizada para a construção deste programa.

Primeiramente, apresentam a modelagem para um problema mais simples, com dois portos e duas viagens (chamado pelos autores de TPTV - "two ports - two voyages"). São considerados na modelagem os estoques de contêineres disponíveis (em estoque ou alugados), a quantidade de contêineres em trânsito e a capacidade de reposição em cada viagem e tais informações são julgadas suficientes para a utilização do modelo de programação dinâmica. As mudanças entre estes estados ocorrem de acordo com as decisões tomadas, por exemplo, a quantidade de contêineres a serem alugados e as reposições realizadas, e os processos estocásticos que envolvem as demandas em cada porto.

As decisões sobre aluguel e reposição de contêineres, na pratica, devem ser tomadas para um evento de partida de um navio de determinado porto. Como existem dois eventos de partida em um problema TPTV, os tomadores devem considerar duas decisões ao utilizar o programa.

Ao generalizar o modelo construído para o TPTV, Lam et al. (2007) criaram um sistema denominado MPMV ("multiple-ports multiple voyages" ou múltiplos portos e múltiplas viagens), cuja modelagem é similar ao sistema TPTV, com a diferença de que haverá mais de dois subestágios na resolução do modelo. Neste modelo com múltiplas viagens deverão ser definidos os pares de origem e destino para cada viagem, além de se considerar as capacidades de transporte das embarcações em cada trecho e definir as demandas estocásticas de acordo com os pares de origem e destino definidos. Obviamente, haverá maior complexidade computacional, fazendo-se necessárias certas aproximações em algumas situações. 
As aproximações adotadas para a resolução dos dois modelos considerados (PTV e MPMV) são baseadas em um algoritmo de iterações (API) utilizado por diversos autores, mas pouco comum em questões relacionadas à logística. As características utilizadas na aproximação são as variáveis de estado do problema (níveis de estoque, quantidades de contêineres alugados e quantidade de contêineres em transito). Com o auxílio do Solver do Excel®, Lam et al. (2007) resolveram os problemas de cada subestágio para chegar à solução do problema.

Di Francesco; Crainic e Zuddas (2009) apresentam um trabalho no qual é proposto um modelo de otimização denominado multi-cenário que se utiliza de informações provenientes das empresas de navegação. A modelagem apresentada leva em consideração a incerteza natural de alguns parâmetros com certa dificuldade de serem determinados através de uma simples análise de dados históricos.

Para os autores, existem duas formas de abordar o problema de reposicionamento e tomadas de decisões acerca dos contêineres vazios:

- Determinística: em problemas resolvidos com técnicas determinísticas assume-se que são conhecidas todas as informações e planos de reposicionamento existentes, não considerando incertezas nos dados;

- Estocástica: modelos estocásticos partem da necessidade de se conhecer distribuições estatísticas e incertezas que surgem a partir de uma amostra de dados existente.

Acerca das abordagens possíveis para o problema de reposicionamento de contêineres vazios, os autores também afirmam que formulações determinísticas podem ser ineficientes devido à incerteza relacionada à demanda e à oferta futura e, portanto, há diferenças entre os dados previstos e as quantidades movimentadas. Di Francesco; Crainic e Zuddas (2009) destacam que não existem trabalhos que quantifiquem as verdadeiras perdas em termos de lucros e eficiência provenientes da utilização de um modelo determinístico. Ainda assim, os autores optaram por construir um modelo determinístico de otimização das realocações de contêineres vazios entre diferentes portos. 
Di Francesco; Crainic e Zuddas (2009) utilizaram as opiniões colhidas nas empresas de navegação para determinar as distribuições de parâmetros incertos e, a partir disso, são criados diferentes cenários (abordagem multicenário).

Dentre os parâmetros desconhecidos podem ser citadas as demandas e ofertas futuras, a capacidade das embarcações e a quantidade máxima de contêineres vazios que podem ser carregados e descarregados. Dados com baixa qualidade podem ser extraídos de bases históricas, sendo utilizados para estimativas destes parâmetros incertos.

Considerando a premissa de que portos pequenos mantêm estoques provisórios de contêineres vazios, enquanto os portos maiores podem estocálos por longos períodos, os autores construíram uma rede que representa instantes distintos, nos quais os navios atracam em determinado porto e carregam ou descarregam contêineres. Nesta rede, os nós representam os portos, replicados a cada período do horizonte de tempo considerado, e as embarcações nos períodos em que estas chegam aos portos.

Este modelo de otimização considera apenas os transportes de contêineres vazios próprios, não possibilitando a análise do impacto do aluguel de contêineres por períodos curtos (aluguéis por longos períodos podem ser considerados como frota própria de contêineres).

Para que sejam definidas as decisões de transportes, o modelo de $\mathrm{Di}$ Francesco; Crainic e Zuddas (2009) considera a introdução do schedule de cada navio incorporado à resolução. São incorporadas também restrições que garantam o equilíbrio entre a oferta e a demanda em todos os portos, o limite máximo dos estoques dos portos maiores (o modelo diferencia os portos considerados grandes, que possuem estoque cativo, daqueles considerados pequenos), os limites de tempo em que um porto pequeno pode estocar um contêiner vazio e as capacidades dos navios, além de buscar a minimização dos custos de carregamento, descarregamento, reposicionamento e estocagem de contêineres (consequentemente, o custo total da operação).

Segundo Di Francesco; Crainic e Zuddas (2009), a modelagem concebida indicaria políticas efetivas caso os dados disponíveis sejam confiáveis e os 
eventos futuros ocorram conforme previsto. De acordo com estes, os parâmetros incertos são mais precisos nos primeiros períodos do horizonte de planejamento. Pode-se considerar que as opiniões dos especialistas consultados sejam confiáveis para os primeiros dois períodos, sendo que a partir do terceiro período os resultados possam apresentar falhas devido à incerteza dos dados. Para mitigar este efeito da incerteza, os autores sugeriram a geração de cenários com diferentes valores para os dados incertos e a atribuição de diferentes pesos para os resultados obtidos.

Song e Dong (2010) tratam o reposicionamento de contêineres vazios como um dos principais problemas para as empresas de navegação, representando grande parte dos movimentos efetuados com contêineres nos oceanos. Segundo os autores, muitos fatores contribuem para a necessidade destes movimentos, entre eles a falta de equilíbrio entre oferta e demanda de contêineres (cita-se o exemplo da rota Trans-Pacifica, na qual o volume transportado da Ásia para o ocidente é muito maior e faz com que haja a necessidade de se transportar contêineres vazios no caminho oposto). Dessa forma, para Song e Dong (2010), o reposicionamento eficiente de vazios é uma "estratégia chave" para que as empresas de navegação possam obter vantagens competitivas.

Os autores citam também que o gerenciamento dos contêineres vazios é relacionado às pesquisas sobre transporte de veículos vazios e, principalmente, logística reversa. Entretanto, eles afirmam existir diferenças significativas entre o gerenciamento de veículos vazios e o gerenciamento de contêineres vazios. Entre essas diferenças está o fato de os contêineres serem transportados por veículos e o fato de, em transporte marítimo, muitos portascontêineres estarem comprometidos com determinada rota fixa por mais de seis meses. Além disso, o transporte de contêineres é naturalmente global (internacional), ao passo que caminhões estão limitados a regiões muito menores.

Song e Dong (2010) destacam que muitos dos trabalhos sobre a navegação de contêineres utilizam uma abordagem determinística, através de formulações clássicas de programação linear. Os estudos que consideram a incerteza e fatores estocásticos começaram a chamar a atenção a partir da década de 
1990. Para estes autores, os modelos matemáticos capturam, frequentemente com sucesso, a natureza dinâmica e estocástica do problema, mas aumentam a preocupação que se deve ter com alguns problemas:

- Escolha de um horizonte de tempo adequado;

- Complexidade computacional e dificuldade de implementação do modelo;

- Robustez do manuseio das incertezas presentes no problema.

Deve-se destacar também que Song e Dong (2010) citam o interesse pelo desenvolvimento da análise de características qualitativas das políticas ótimas de reposicionamento de contêineres.

Através de entrevistas realizadas com algumas empresas de navegação, os autores identificaram uma prática utilizada na redistribuição de contêineres: os mesmos são embarcados sem um destino definido. De certa forma, "tal prática pode tornar a manipulação dos eventos dinâmicos e incertos mais flexível, desde que parte das decisões sobre o reposicionamento possa ser realizada a partir do momento em que mais informações confiáveis são disponibilizadas" (Song e Dong, 2010). Porém, mais custos poderão ser gerados, pois os contêineres vazios podem ocupar espaços em navios que cruzarão longas distâncias.

Formula-se o problema flexibilizando os portos de destino dos contêineres vazios. Primeiramente, determina-se a quantidade e como os contêineres vazios serão embarcados nos portos de origem e, depois, a quantidade e como estes contêineres serão desembarcados nos portos de destino. Feito isso, os autores apresentam uma política de destinação flexível, avaliando a eficiência desta política e comparando-a com uma política convencional na qual os portos de destino são definidos antes de os contêineres serem embarcados.

A formulação construída por Song e Dong (2010) considera um sistema de navegação (uma frota de navios, frota de contêineres e um conjunto de portos) no qual as embarcações visitam os portos de acordo com um roteiro préestabelecido. Para formulação do problema, são adotadas algumas premissas, como a não utilização da atividade de leasing de contêineres, a rotas prédefinidas para serem seguidas pelos navios, perda da demanda não atendida, 
resultando em custos e que as decisões sobre quais e quantos contêineres vazios são descarregados são tomadas em todos os portos.

É construído um modelo complexo de programação linear no qual as variáveis de decisão utilizadas são a quantidade de contêineres vazios que embarcam ou desembarcam de uma embarcação $v$ em determinado porto $i$ em um instante $k$ e o número de contêineres carregados que embarcam em uma embarcação, em determinado porto, em determinado instante. A função objetivo a ser minimizada no problema é a soma total de custos. Dentre os custos envolvidos, consideram-se:

- Custos de armazenamento de contêineres vazios nos portos;

- Custos relacionados à demanda não atendida devido à incapacidade que determinada embarcação tem de transportar ou por falta de contêineres vazios;

- Custos de embarque e desembarque de contêineres vazios e carregados;

- Custos de transporte dos contêineres entre os portos do conjunto considerado.

Além de todas as características da formulação e do problema de Song e Dong (2010) já citadas, os autores citam, ainda, duas preocupações existentes em relação ao reposicionamento dos contêineres vazios:

- Quando e quantos contêineres vazios que embarcarão nos navios poderão ser reposicionados para outros portos?

- Quantos e onde os contêineres vazios embarcados poderão ser descarregados dos navios?

De acordo com os autores, o principal objetivo de seu artigo é apresentar uma regra que facilite a resolução do problema proposto com flexibilidade nos portos de destino, visto que as circunstâncias dinâmicas das operações e o caráter de incerteza nos parâmetros e variáveis fazem com que a determinação da solução ótima do problema seja muito difícil. Sendo assim, Song e Dong (2010) criaram a "Regra de destinação de portos flexível" (Flexible destination port policy - FDP), que parte do principio de que, devido ao imbalance existente no transporte de contêineres, alguns portos têm oferta e outros 
possuem demanda de contêineres vazios e isso possibilita a divisão do conjunto de portos considerados em dois grupos distintos. A partir da regra de destinação de portos flexíveis, as decisões de reposicionamento dos contêineres vazios serão tomadas quando uma embarcação estiver partindo de um porto e serão seguidos quatro passos:

1. Identificação da direção de reposicionamento no inicio do período analisado (divisão dos portos em dois conjuntos);

2. Determinação dos valores limites para o estoque de contêineres vazios em cada porto ( $D$ é valor mínimo e U é o valor máximo);

3. Computação da quantidade estimada de contêineres a serem importados e exportados em todos os portos no instante $\mathrm{k}$;

4. Determinação do número de contêineres a serem exportados no porto atual levando-se em consideração as demandas nos outros portos e a capacidade das embarcações.

Quando um navio chegar a um porto para ser descarregado, a quantidade de contêineres vazios que serão deixados naquele porto será determinada de acordo com a necessidade de contêineres existentes no terminal, da capacidade do navio ou ainda se o porto for o último porto do conjunto de portos com déficit de recipientes vazios a ser visitado.

De acordo com o modelo, a utilização da "Regra de destinação de portos flexível" favorece o sistema, fazendo com que sejam obtidos custos menores que os obtidos com a regra de destinação pré-determinada. Conforme o tamanho da frota utilizada cresce, ambas as regras convergem para o caso sem reposição de contêineres vazios. A pesquisa concluiu, portanto, que a "Regra de destinação de portos flexível" é apropriada e gera lucros em relação à regra de destinação pré-determinada.

Zambuzi (2010) propõe um modelo de fluxo em rede, multi-produto, para auxiliar no planejamento e gerenciamento dos movimentos dos contêineres vazios em um conjunto de portos definido, buscando equilibrar as ofertas e demandas em cada um destes terminais, ao menor custo e obedecendo a possíveis restrições de capacidade dos meios de transporte utilizados. A autora confirma a relevância de se estudar o tema a partir do crescimento do 
transporte marítimo de contêineres, que em 2008 atingiu 1,3 bilhões de toneladas ou 137 milhões de TEU's e o fato de as demandas por contêineres vazios necessitar ser atendida em datas e locais específicos, o que diminui a tolerância por atrasos na recepção destes.

Para Zambuzi (2010), um programa que possibilite a otimização de um sistema de transporte de contêineres e alocação de vazios pode ser benéfica para toda a sociedade, visto que uma diminuição dos custos pode ser transmitida para consumidores finais dos produtos. Um fator de complicação apresentado é o fato de não haver janelas de entrega para contêineres vazios, pois estes devem ser entregues tão logo são solicitados, o que deixa pequena margem para erros de planejamento. Portanto, deve haver um bom plano de realocação de contêineres vazios, baseado em relatórios e projeções de demanda, para que não haja falta de equipamentos e, principalmente, que isso não acarrete em perda de fretes.

Devem-se destacar as premissas adotadas pela autora em seu trabalho, entre elas:

- O transporte dos vazios por navios depende da passagem desses nos portos dentro do horizonte de tempo planejado. Um mesmo navio pode passar por um porto mais de uma vez durante esse período;

- O transporte de vazios por modais terrestres (rodoviários e ferroviários) só pode ser feito se existir vias que liguem os portos. Para representar grandes distancias terrestres no modelo, pode-se não considerar a ligação entre os portos;

- Consideram-se somente operações de embarque para contêineres vazios que serão utilizados em outros portos e desembarque de contêineres que atenderão a demanda do porto no qual o navio opera, não sendo considerado o reposicionamento de vazios nos navios;

- Não são considerados depósitos externos aos portos na modelagem. Alem disso, a demanda e a oferta de contêineres representa a soma de todos os vazios de clientes que são atendidos por aquele porto;

- Os contêineres vazios disponíveis são a soma dos armazenados, com os que retornam de clientes, os que podem ser alugados e os que são desembarcados de um navio; 
- Não é modelado o transporte dos contêineres dos portos para os clientes;

- Contêineres vazios demandados por um porto não precisam ser entregues no período exato, podendo ser armazenados após ser entregues com antecedência;

- As operações de leasing consideram a incorporação dos contêineres vazios ao sistema, não havendo a devolução após determinado período;

- Vazios que atendem a determinada demanda não fazem mais parte do sistema, podendo ou não retornar em instantes posteriores como oferta;

- Não é permitida a substituição entre tipos de contêineres;

- O espaço que pode ser ocupado pelos contêineres vazios nos diferentes modais dependerá da disponibilidade de veículos nos modais terrestres e espaços não ocupados por contêineres cheios nos navios;

- O custo analisado é composto pelas parcelas referentes a carregamento, descarregamento, armazenamento, transporte e aluguel de contêineres vazios.

Zambuzi (2010) optou por criar uma rede na qual os nós representam o tempo e o espaço, ou seja, um determinado porto em um período de tempo, que pode ser a representação do tempo em horas, dias, semanas, etc. Os arcos da rede representam os fluxos de vazios, seja de um porto para outro, de um porto para ele mesmo em instantes diferentes, de um porto para um cliente, entre outros.

Para representar as incertezas existentes, Zambuzi (2010) cita um modo implícito, no qual as ofertas e demandas de contêineres vazios são deslocadas no tempo de acordo com um fator adotado, e um modo explícito, no qual diferentes cenários são processados e têm seus resultados analisados, o que necessita de rapidez no processamento e alterações manuais nos parâmetros de entrada. A autora incorpora as incertezas a partir do método explicito.

Ao testar as aleatoriedades das programações dos navios em seu modelo, Zambuzi (2010) pôde notar o forte impacto que tais incertezas podem exercer no planejamento da empresa, o que reforça a ideia de que um modelo de tomada de decisão de alocação dos contêineres vazios deve considerar as variações possíveis nos dados de entrada e scheduling dos navios para que os 
dados de entrada sejam utilizados com maior segurança. Os níveis de incerteza e distribuições estatísticas ideais podem ser extraídos de bases de dados da empresa de navegação.

Para validação do modelo construído, Zambuzi (2010) processa os dados de entrada de um cenário baseado na solução apresentada por Rezende (2003), obtendo uma solução com menor custo. A autora também utiliza dados reais fornecidos pela empresa de navegação Hamburg Süd e acaba por encontrar resultados mais eficientes que aqueles fornecidos para comparação, comprovando a confiabilidade do programa. Para a autora, suas maiores contribuições são a criação de uma interface totalmente amigável e de fácil manipulação e a flexibilidade do modelo em relação à adoção de novas restrições, o que transformam seu modelo em uma ferramenta de grande utilidade à tomada de decisões no planejamento de alocação de contêineres vazios.

\subsection{CONCLUSÃO DA REVISÃO BIBLIOGRÁFICA}

Observou-se que a navegação marítima de contêineres é um tema que possui espaço cada vez mais significativo nos estudos e pesquisas elaborados nos últimos anos, em virtude da quantidade de trabalhos encontrados. Entretanto, a grande maioria destes trabalhos contém um enfoque maior nas operações realizadas no dia-a-dia, como o reposicionamento de contêineres e decisões relacionadas ao leasing de frotas de terceiros.

É senso comum, entre todos os autores, a necessidade de se reduzir os custos desta operação e possibilitar assim que as companhias de navegação incrementem suas margens de lucro em um mercado envolto em uma competitividade intensa (ROI (2002) estima que um decréscimo de 10\% em gastos com reposicionamento de contêineres vazios pode aumentar a margem de lucros entre 30 e $50 \%$ ).

Nota-se também a variedade de metódos utilizados para a resolução de problemas de reposicionamento e transporte de contêineres, como a utilização 
de técnicas de programação linear, a partir de redes e fluxos de cargas, técnicas de simulação e formulações dinâmicas matemáticas.

Destaca-se, também, que poucos são os estudos elaborados que considerem diretamente o dimensionamento da frota de contêineres de uma empresa de navegação, atividade relacionada ao planejamento estratégico de um armador e que possibilita a diminuição de custos com armazenamento, reposicionamento e perda de clientes por falta de contêineres. Por outro lado, deve-se encarar o reposicionamento de vazios como um grande aliado na diminuição de estoques nos portos e uma opção sempre importante no gerenciamento das empresas de transporte marítimo.

Outro fato importante e que merece destaque é a preocupação que a grande maioria dos autores tem em relação ao caráter aleatório de alguns parâmetros que compõem o problema de alocação dos contêineres vazios, convergindo para a necessidade de considerar as incertezas inerentes a variáveis como o instante de chegada e partida dos navios, atrasos na chegada de contêineres por terra (aluguel, inclusive), capacidade de transporte dos navios, demanda e oferta de contêineres nos terminais, etc. Muitos dos autores buscam atrelar à sua modelagem alguma ferramenta ou artifício que considere o caráter estocástico do problema, mesmo que a técnica utilizada seja puramente determinística.

A criação de modelos determinísticos para a resolução do problema da logística de contêineres vazios é bem fundamentada na simplificação que um problema tão complexo pode obter. Entretanto, considerar a natureza estocástica do problema garante maior confiabilidade aos resultados obtidos, e estes modelos determinísticos não propiciam isso com a praticidade adequada.

Com base na revisão bibliográfica, onde poucos trabalhos utilizaram a técnica de simulação e nenhum deles foi utilizado para o dimensionamento da frota de contêineres, buscou-se aplicar essa técnica nesse problema de dimensionamento, pelas seguintes razões:

- É possível caracterizar o processo de navegação, de carregamento e descarregamento dos contêineres a bordo;

- É possível caracterizar a circulação de contêineres em terra; 
- É possível caracterizar a interface de carga e descarga dos navios nos portos;

- É possível caracterizar a linha do tempo dos navios durante o ciclo de navegação e a linha do tempo dos contêineres durante a circulação em terra;

- É possível considerar a aleatoriedade e as incertezas das variáveis utilizadas.

Conclui-se, portanto, que técnicas com características estocásticas, como a simulação matemática de eventos discretos, por exemplo, podem ser ferramentas de grande utilidade para a resolução dos problemas de planejamento e alocação dos contêineres vazios, uma vez que possibilitam a consideração direta da aleatoriedade e incerteza das variáveis citadas.

No próximo capítulo será apresentado o modelo de simulação para o dimensionamento da frota de contêineres. 


\section{MODELO DE SIMULAÇÃO DA MOVIMENTAÇÃO DE CONTÊINERES CHEIOS E VAZIOS COM FROTA DE NAVIOS EM ROTA DEDICADA}

O presente capítulo apresenta a modelagem conceitual e uma descrição detalhada do modelo de simulação construído para o desenvolvimento da pesquisa.

Preliminarmente, apresenta-se a metodologia da aplicação da simulação de sistemas por eventos discretos, além de alguns argumentos para justificar a utilização desta técnica.

Será apresentada também a interface de entrada de dados, que deve ser utilizada para a configuração dos cenários desejados e verificação dos resultados no log de navios gerado pelo modelo.

\subsection{SIMULAÇÃO}

Destaca-se, nesta seção, que a simulação à qual este estudo irá se referir é a chamada simulação de eventos discretos. Tal observação possui relevância devido ao fato de existirem ainda outros tipos de simulação, como a simulação de "Monte Carlo" e a simulação contínua (Chwif e Medina, 2007).

Pegden et al. (1990), por exemplo, se refere à simulação como sendo um modo de se representar um sistema real através de um modelo computacional que permita o entendimento de todas as ações que ocorrem em um sistema, na sequência exata em que acontecem, e avaliação de alternativas que possam trazer maior eficiência às operações, mostrando um grande potencial em ser utilizada como ferramenta de auxílio a tomadas de decisões.

Também deve se dar a importância necessária ao tratamento dos dados disponíveis, pois estes exercem grande influência nos resultados obtidos.

A Figura 4-1 resume o processo de criação de um modelo de simulação. 


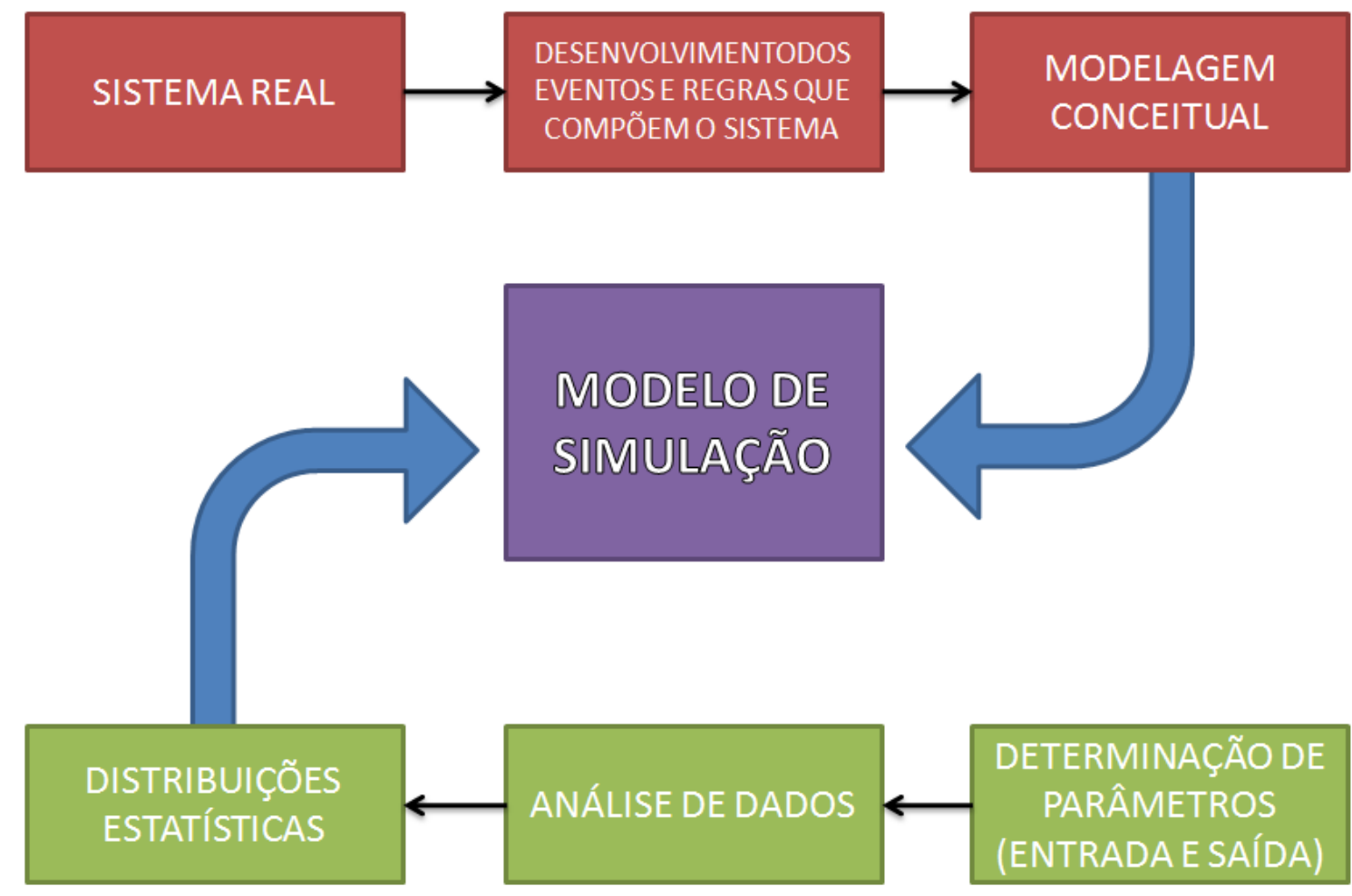

Figura 4-1: Processo de criação de um modelo de simulação

Pode-se afirmar que o desenvolvimento tecnológico é um grande facilitador da utilização das técnicas de simulação, uma vez que processadores mais avançados e rápidos possibilitam que se simulem modelos cada vez mais complexos e robustos, em tempos consideravelmente pequenos e com possibilidade de grande detalhamento das respostas a serem obtidas.

A simulação de eventos discretos foi adotada como a técnica para resolução do problema apresentado nesta dissertação por apresentar grandes vantagens em relação a outras técnicas conhecidas. Entre estas vantagens, podem ser citadas a possibilidade de rápida avaliação de estratégias propostas, a utilização de dados pouco robustos, maior facilidade em se detalhar um sistema complexo, a compreensão de quais variáveis são realmente influentes e orientam os resultados obtidos, identificação dos "gargalos" do sistema e representação verdadeira dos acontecimentos reais, interligando os subsistemas e possibilitando a avaliação completa da interdependência entre estes. 
Como apresentado na revisão bibliográfica, poucos estudos utilizaram a simulação de eventos discretos para dimensionar a frota de contêineres disponível para a companhia de navegação, por si só um problema também de grande complexidade. A simulação de eventos discretos possibilita a resolução do problema de dimensionamento da frota de contêineres atrelado às inúmeras restrições existentes e ainda levando em consideração o reposicionamento de contêineres. Existe também o fato de a simulação permitir que se abra mão de muitas simplificações, necessárias para a resolução de outros modelos analíticos, como os que se utilizam de programação matemática.

\subsection{INTRODUÇÃO À MODELAGEM DE SIMULAÇÃO PARA O DIMENSIONAMENTO DA FROTA DE CONTÊINERES}

Foi criado um modelo de simulação para simular uma rota de transporte marítimo de contêineres entre os portos em um ciclo fechado com determinada frota de navios.

Para essa simulação consideram-se algumas premissas, como a disponibilidade de um berço em cada terminal incluído no cenário simulado e a possibilidade de configuração do sistema, variando-se o número de portos visitados, o tamanho da frota e as matrizes de cargas a serem atendidas.

O modelo de simulação compreende dois submodelos interligados entre si: o submodelo de circulação dos navios e o submodelo de circulação dos contêineres em terra, apresentados nesta seção.

4.2.1. Submodelo: Circulação dos navios

O primeiro submodelo que compõe a simulação do transporte de contêineres em um ciclo fechado representa as viagens dos navios e operações portuárias de acordo com as rotas e matrizes de carga pré-definidas. As matrizes de 
cargas dos navios foram estabelecidas em uma fase de planejamento, de forma a garantir que o armador tenha rentabilidade caso atenda, no mínimo, essas cargas representadas nestas matrizes.

Em outras palavras, pode-se dizer que a matriz de cargas representa a quantidade de contêineres a serem embarcados em cada porto, que garante uma ocupação mínima dos navios e gerem lucros para a companhia de navegação.

Neste submodelo, primeiramente, são criadas as entidades navios, em quantidade definida na interface de entrada de dados. Sobre estes navios, devem ser informadas (na interface de entrada de dados) algumas características como a velocidade e a capacidade, e a matriz de cargas a ser atendida entre portos e por navio alocado na rota.

Criados os navios da frota considerada, o modelo atribui as características específicas de cada um, como o número de identificação, o número da viagem (no caso, a primeira viagem de cada navio) e as sequências dos portos que serão visitados nas rotas consideradas para os mesmos. Os navios são, então, posicionados nos portos definidos como os iniciais de cada par navio-viagem. Em um primeiro momento da construção do modelo, adotou-se a premissa de que todos os navios iniciarão suas viagens no porto 1, sendo que devem partir com um intervalo entre eles determinado pela relação entre o tempo de ciclo estimado e o tamanho da frota de navios (headway), em horas. A partir disso, o modelo considera as entidades navios, separadamente.

Com o primeiro porto da sequência de cada navio já definido, é registrado também o instante inicial das operações, de modo a facilitar a coleta de estatísticas do modelo. Feito isso, o primeiro porto é alocado e ali devem ocorrer as operações portuárias de acordo com a produtividade inserida na interface de entrada de dados.

Os dados de entrada também são utilizados para determinação dos estoques iniciais em todos os portos: estoque inicial de contêineres vazios, estoque inicial de contêineres cheios a serem carregados nos navios (out) e estoque inicial de contêineres cheios a serem enviados aos clientes em terra (in). 
Dentre as operações que o modelo realiza cada vez que um porto é alocado por um navio, considera-se, inicialmente, o descarregamento de contêineres embarcados com destino naquele porto. Em seguida, considera-se 0 carregamento (havendo estoque suficiente de contêineres cheios no porto) e a decisão sobre o reposicionamento ou não dos contêineres vazios, a partir da verificação que é realizada na interface de entrada de dados, se um porto tem oferta ou demanda por contêineres vazios. Essa verificação considera as matrizes de cargas dos navios para determinar se os portos apresentam desequilíbrio entre oferta e demanda por contêineres e um cálculo simples prevê se haverá falta ou excesso de vazios em cada porto.

Logicamente, durante a operação nos portos, existe uma atualização dos estoques de contêineres cheios e vazios, realizada de acordo com a matriz de cargas correspondente ao navio em operação.

A lógica de carregamento dos navios percorre a sequência específica e a matriz de cargas, realizando a soma que indica quantos contêineres deverão ser descarregados nos próximos portos a serem visitados. Depois disso, é criado um atributo carregamento, para cada um dos próximos portos da sequência, com a quantidade de contêineres embarcados naquele navio e que deverão ser descarregados adiante.

No procedimento de carregamento de contêineres para os portos posteriores da rota, podem ocorrer duas situações: existe estoque de contêineres cheios (out) suficientes para atender a matriz de carga ou não existem contêineres suficientes, situação na qual serão repartidos proporcionalmente os contêineres disponíveis de acordo com a matriz de carga.

Para esta última situação, é calculada também a perda de transporte de contêineres, dada pela diferença entre a quantidade que deveria ser embarcada e a quantidade que realmente será levada pelo navio. Como esse valor pode ser um número decimal e não inteiro (decorrência do cálculo realizado), é adicionada uma lógica para corrigir tais quantidades (um contêiner é um objeto indivisível), na qual o balanço de massa do modelo é mantido. 
Terminadas as operações no porto, é registrado o instante de saída do navio, podendo este receber um próximo navio, enquanto o navio que acabara de ser atendido seguirá sua viagem para o próximo porto da sequência.

O tempo de viagem até o próximo porto é determinado pela velocidade dos navios e pela matriz de distâncias entre os portos, dados estes preenchidos na interface de entrada de dados.

Caso o porto não seja o último da sequência, o navio deve seguir para o próximo porto e repetir todos os procedimentos desde a alocação do recurso porto até o fim de todas as operações. Por outro lado, caso o porto em questão seja o último da sequência, o navio retornará para o primeiro porto do ciclo e o modelo marcará todos os instantes de entrada e saída em cada terminal.

Além disso, existem atualizações dos estoques ao longo da simulação que são registradas na interface de resultados, gerando assim um log muito útil para a verificação dos resultados.

É atualizado, então, o número da próxima viagem do navio e o mesmo repetirá a sequência, descarregando ainda, contêineres que foram carregados na viagem anterior em portos posteriores da sequência (por exemplo, se há demanda do porto 2 para o porto 1 , e a sequência de viagens considera as visitas aos portos em ordem crescente, quando o navio iniciar a segunda viagem no porto 1 , a demanda proveniente do porto 2 será descarregada).

Por fim, para determinar a quantidade de viagens (ciclos) de cada navio, o modelo calcula, primeiramente, a duração de uma viagem redonda, contabilizando o tempo decorrido desde que o primeiro porto da sequência é alocado, até o momento em que o navio retorna para este porto. Depois disso, é calculada a razão entre o tempo de duração da simulação e a duração de uma viagem, obtendo-se o número de viagens redondas ou a quantidade de ciclos, para cada navio, simulados. 
4.2.1.1. Determinação de portos demandantes e ofertantes

O reposicionamento de contêineres é alvo de estudos específicos dentro das companhias de navegação. Considerar este reposicionamento aumenta a complexidade existente no transporte de contêineres, devido à grande quantidade de variáveis que se relacionam. Um planejamento adequado dessa logística de vazios possui grande potencial em diminuir os custos da empresa e possibilitar maiores lucros devido à maior disponibilidade de recipientes e diminuição das perdas de transportes.

A possibilidade de se reposicionar os contêineres vazios entre os portos é considerada no submodelo de circulação dos navios, como relatado anteriormente. Para isso, o modelo reconhece se determinado porto de uma sequência possui características de um porto ofertante ou demandante por vazios. Tal reconhecimento é realizado ainda na interface de entrada de dados, a partir de um cálculo realizado com os dados informados nas matrizes de cargas dos navios que compõem a frota.

Com os valores informados nas matrizes de carga, calcula-se a quantidade de contêineres cheios que devem ser retirados de um porto e a quantidade que deve ser descarregada neste mesmo porto durante uma viagem do navio. Depois disso, subtrai-se da quantidade descarregada o número de contêineres retirados, obtendo-se o saldo de contêineres que deve permanecer no porto depois que o navio termina sua operação. É esse saldo que determina para o modelo se o porto é ofertante ou demandante por vazios: nos portos em que o saldo é positivo, a interface reconhece um porto ofertante. Caso contrário, se o saldo for negativo, o porto será demandante.

A partir desta determinação, são reconhecidos os portos dos quais poderão ser retirados os contêineres vazios e aqueles que deverão receber estes objetos, a partir de uma ordem de prioridade determinada pela comparação entre as quantidades médias demandadas em todos os portos da rota (saldo).

Cabe ressaltar que esse saldo se acumularia ao longo do tempo caso não houvesse o reposicionamento (em portos ofertantes, os estoques de 
contêineres cresceriam enquanto que nos demandantes acumular-se-iam perdas de transporte por falta de contêineres).

Verificados quais portos são ofertantes e quais deles são demandantes por vazios, é o momento de determinar as quantidades a serem retiradas ou descarregadas em cada porto. Tais quantidades são calculadas levando-se em consideração três fatores: a sequência de portos visitados, os saldos de contêineres vazios ao fim de um ciclo e os fluxos entre esses saldos.

Ordenados os portos de acordo com a sequência de visitas, estes devem ser divididos em grupos que se iniciam por portos ofertantes. Nestes grupos, retirase dos portos ofertantes a quantidade máxima que sobrará em um ciclo, ou seja, retira-se dos portos ofertantes uma quantidade igual ao saldo positivo daquele porto. Calcula-se, então, a porcentagem deste saldo que deve ser descarregada nos portos que sucedem este ofertante até que o navio chegue a outro porto ofertante.

Por exemplo, se são retirados 428 contêineres em um porto ofertante e o porto seguinte é demandante de 376 contêineres, sabe-se que naquele porto serão descarregados $87,9 \%$ dos vazios a bordo, fazendo com que sobrem, no navio, 52 contêineres vazios. Se o próximo porto visitado for demandante, será calculada a porcentagem dos vazios que restaram a bordo que será descarregada, caso contrário, serão carregados novos vazios, acumulando a quantidade de contêineres a bordo. Exemplificando, se o porto seguinte tiver um saldo positivo de 818 contêineres (ofertante, portanto), estarão a bordo do navio 870 contêineres vazios para serem descarregados nos portos.

Tal mecanismo funciona até o fim da sequência de portos visitados, momento no qual a quantidade de vazios a bordo deve ser igual a zero, pois o balanço de massa é mantido já que, apesar de poder haver um desbalanceamento na matriz de cargas, todos os fluxos que saem dos portos, chegam a outros portos, fazendo com que a somatória de todos os saldos seja igual a zero.

A Figura 4-2 exemplifica este mecanismo para reposicionamento de contêineres, mostrando as porcentagens dos contêineres a bordo que serão descarregadas em cada porto demandante. 


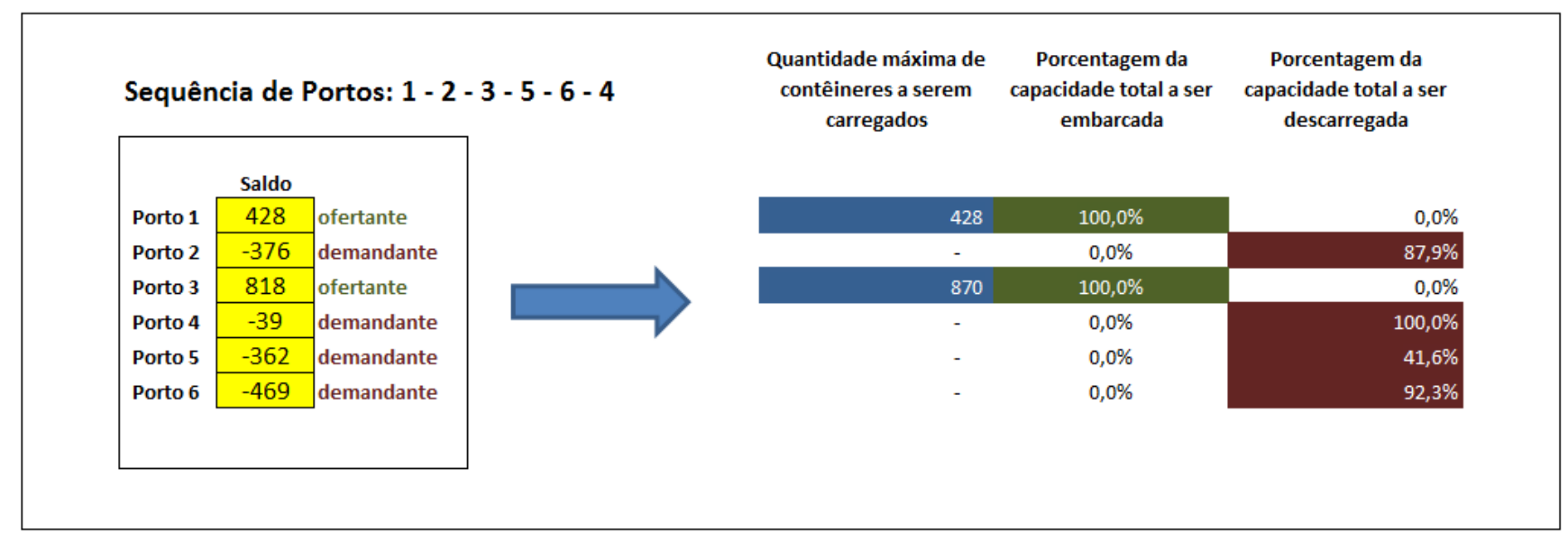

Figura 4-2: Representação do mecanismo de reposicionamento de contêineres vazios

No exemplo da Figura 4-2, apresenta-se um cenário cuja sequência de portos visitados é $1-2-3-5-6-4$, na qual somente os portos 1 e 3 são ofertantes e os outros, demandantes. Note que depois de visitar o porto 1 e retirar deste 428 contêineres vazios, o reposicionamento necessário no porto 2 é de $87,9 \%$ do total a bordo, e os contêineres carregados no porto 3 se acumulam, sendo descarregados nos portos 5, 6 e 4 posteriormente.

A Figura 4-3 apresenta uma representação esquemática das quantidades de contêineres que são carregados e descarregados nos portos a cada viagem dos navios. 


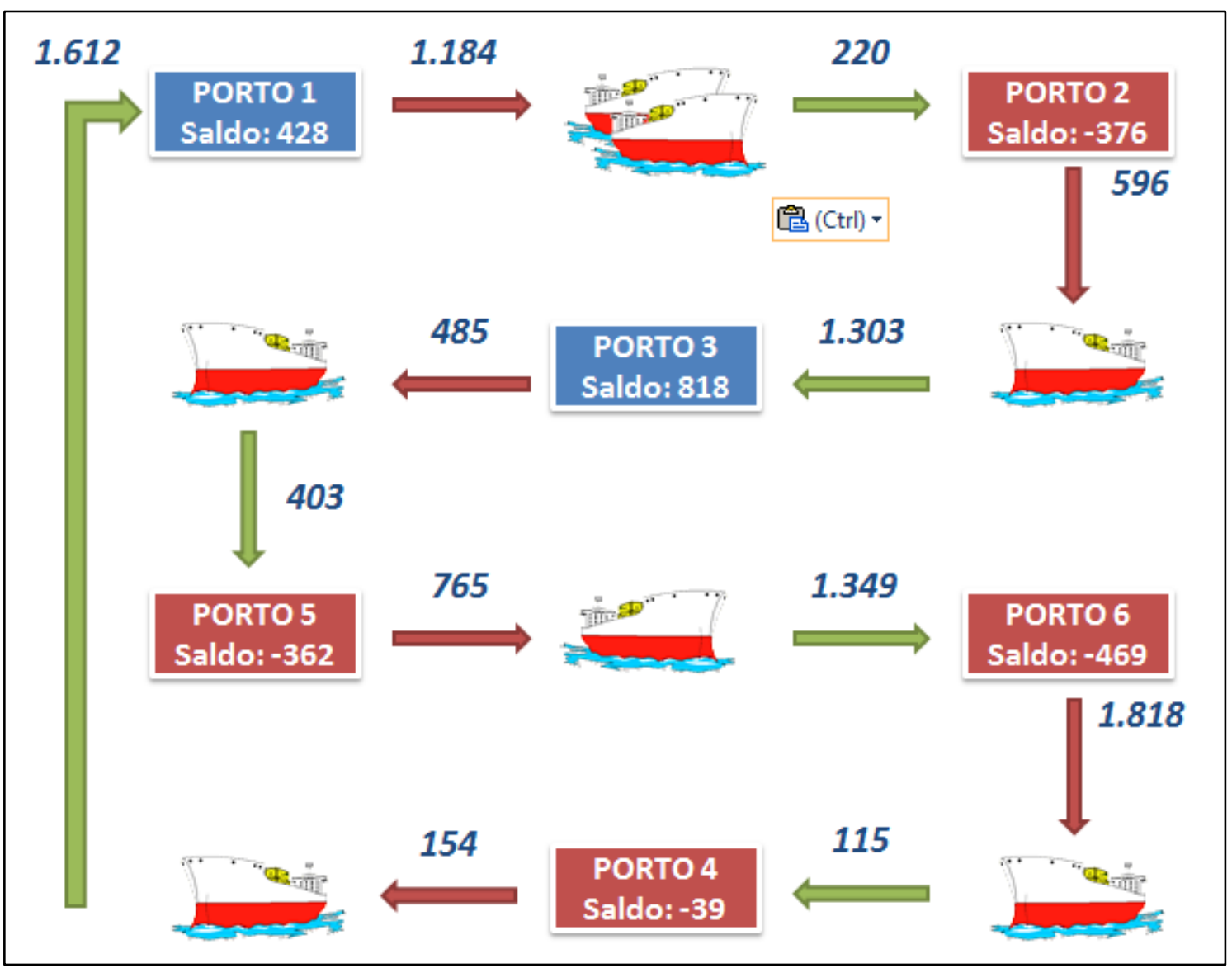

Figura 4-3: Representação da quantidade de contêineres carregados e descarregados em cada porto

Nesse momento, destaca-se que o reposicionamento de vazios é uma estratégia que será utilizada para diminuir a quantidade de vazios dos estoques iniciais dos portos, sendo que é objetivo deste trabalho dimensionar a frota de contêineres no sistema.

É importante destacar também que a capacidade de transporte de vazios dos navios utilizados é uma variável muito importante nesse processo, pois, se houver grande limitação desta quantidade, o reposicionamento realizado pode se distanciar da estratégia ideal, já que nem todos os contêineres que sobram em um porto ofertante podem ser embarcados. 


\subsubsection{Submodelo: Circulação dos contêineres em terra}

Além do submodelo de circulação de navios já apresentado anteriormente, foi construído um submodelo para representar a circulação dos contêineres em terra. Esse submodelo trata das operações realizadas com os recipientes vazios que estão nos portos e são enviados para carregamento nos clientes, voltando cheios para serem embarcados e transportados, e com os contêineres que são desembarcados cheios nos portos e são enviados para os destinatários, que os esvaziam e os devolvem vazios aos depósitos portuários que estão localizados em regiões próximas aos portos considerados na simulação.

As entidades geradas no início da simulação por este submodelo são denominadas entidades de circulação nos portos, sendo que o número de "circulações" geradas é igual à quantidade de portos que compõem a rota indicada na interface de entrada de dados. Depois de criadas estas entidades, o modelo nomeia cada uma delas com o número do respectivo porto a qual se refere, e estas serão submetidas aos eventos que podem ocorrer na circulação dos contêineres em terra.

As entidades seguem para um módulo de decisão aleatória, na qual existem duas lógicas diferentes pelas quais podem ser tratadas: a lógica que sorteia (a partir de uma distribuição estatística que leva em consideração os dados provenientes da matriz de carga) a demanda diária de contêineres vazios do porto considerado e que resultará na geração dos contêineres a serem enviados cheios aos terminais para serem embarcados nos navios, e a lógica que deverá tratar os contêineres que vêm cheios dos portos para os clientes em terra e são esvaziados e devolvidos aos depósitos junto aos portos.

Na primeira lógica, a de determinação da demanda diária de vazios dos portos, o modelo verifica se o estoque de contêineres vazios no porto considerado no momento é suficiente para atender à demanda solicitada, verificando ainda se existe um saldo de contêineres que não foi atendido anteriormente. Caso não haja contêineres suficientes, haverá o incremento de um atributo "saldo a atender", específico para cada porto. Tais contêineres vazios se transformam, 
por sua vez, em contêineres cheios que deverão ser embarcados nos portos e, após um intervalo de tempo, o modelo atualiza os estoques de contêineres cheios out nos portos. Tais operações ocorrem diariamente no modelo.

Este intervalo de tempo considerado para a atualização dos estoques representa o tempo de retenção dos contêineres em terra e incorpora a duração de todos os eventos que ocorrem desde a retirada de um contêiner vazio dos depósitos até o momento em que este é entregue cheio para serem embarcados no porto. O modelo considera, para este tempo de retenção, uma distribuição triangular, de acordo com sugestão da empresa de navegação consultada.

A outra lógica existente nesse submodelo de circulação dos contêineres em terra considera as operações de desembarque dos contêineres que chegam cheios aos portos considerados na simulação. A entidade de circulação aguarda um "sinal" que ocorre no submodelo de circulação dos navios e informa a chegada de contêineres cheios aos portos. Com esse sinal, o submodelo de circulação em terra faz com que a variável de contêineres cheios in (contêineres que chegam cheios aos portos, provenientes dos navios) seja retida durante o intervalo de tempo que representa a retenção dos contêineres em terra e, depois desse período, se transforme em um incremento da variável de estoque de contêineres vazios nos depósitos localizados junto aos portos considerados.

Cabe destacar, novamente, que os eventos realizados pelas entidades criadas neste submodelo de circulação em terra se repetem diariamente no modelo.

\subsubsection{Dependência entre os submodelos}

As simulações de ambos os processos acontecem simultaneamente e são dependentes somente no que se refere à disponibilidade de contêineres em estoque, tal qual ocorre na realidade. O transporte de contêineres entre os clientes e os terminais nos quais estes serão carregados ou descarregados é a interface entre as duas etapas, fazendo com que os estoques em um local 
sejam modificado por interferência do outro. Em outras palavras, as demandas utilizadas em cada etapa devem estar sincronizadas e serem atualizadas tão logo haja necessidade, mostrando a relação entre as duas lógicas que compõem o modelo.

O submodelo de circulação em terra faz com que contêineres vazios se transformem em contêineres vazios out (aqueles que serão embarcados cheios) e os contêineres cheios in se transformem em contêineres vazios, sempre respeitando o tempo indicado como o tempo de retenção em terra, que inclui as viagens entre portos e depósitos, o tempo de carregamento e descarregamento e um possível tempo de espera.

Para exemplificar a dependência entre os submodelos, o submodelo de circulação dos navios envia, cada vez que são descarregados novos contêineres nos portos, um sinal para o submodelo de circulação em terra, indicando que deve haver, então, a "retirada" de contêineres cheios dos portos e seu esvaziamento.

\subsection{MODELO CONCEITUAL}

Como citado anteriormente, o modelo de simulação proposto neste trabalho considera duas etapas distintas: a circulação da frota de navios prédeterminada entre os portos que compõem o sistema e a movimentação de contêineres, cheios e vazios, em terra, representando o transporte entre os clientes e os terminais de sua área de influência.

Cada uma dessas duas etapas possui suas particularidades e regras independentes, apesar de também estarem ligadas entre si. Isso fez surgir a necessidade de se criar as lógicas separadamente, dentro de um mesmo modelo de simulação, a partir de conceitos diferentes.

A primeira lógica apresentada é a da circulação de navios entre os portos que compõem o sistema. As principais regras adotadas para a criação do modelo conceitual desta lógica são: 
- Os navios, no inicio da simulação, são inseridos em um determinado porto e cumprirão, a partir deste instante, as atividades de descarga, carga e viagens segundo uma sequência de portos previamente definida, em ciclo fechado. Os navios podem ter sequências de portos diferentes, o que torna o modelo mais flexível. A introdução da frota e da sequência de portos será mostrada na interface de entrada de dados;

- Cada navio, ao chegar a um porto, entra em fila, descarrega os contêineres cheios e vazios e carrega outros cheios e vazios, se disponíveis nos estoques correspondentes, com destino aos demais portos da rota. Tais ações ocorrem conforme uma matriz de carga que será apresentada na interface de entrada de dados;

- O modelo analisa se o porto é ofertante ou demandante para realizar o reposicionamento de vazios da maneira mais eficiente possível;

- Caso não existam contêineres cheios ou vazios suficientes para cumprir o que foi programado na matriz de carga, o modelo computa esse déficit como perda de carga transportada pelo navio;

- A quantidade total de contêineres movimentada pela frota de navios inserida é obtida quando se insere inicialmente no modelo uma quantidade de contêineres nos estoques de cheios e vazios nos portos, grande 0 suficiente para que a frota inserida sempre cumpra 0 planejamento de matriz de cargas considerada. A partir deste número, buscar-se-á a quantidade de contêineres a serem inseridas nos estoques nos portos que minimize a soma da perda de transporte com a frota de contêineres inserida nos estoques (função objetivo);

A Figura 4-4 apresenta o fluxograma do modelo conceitual da lógica de circulação dos navios. 


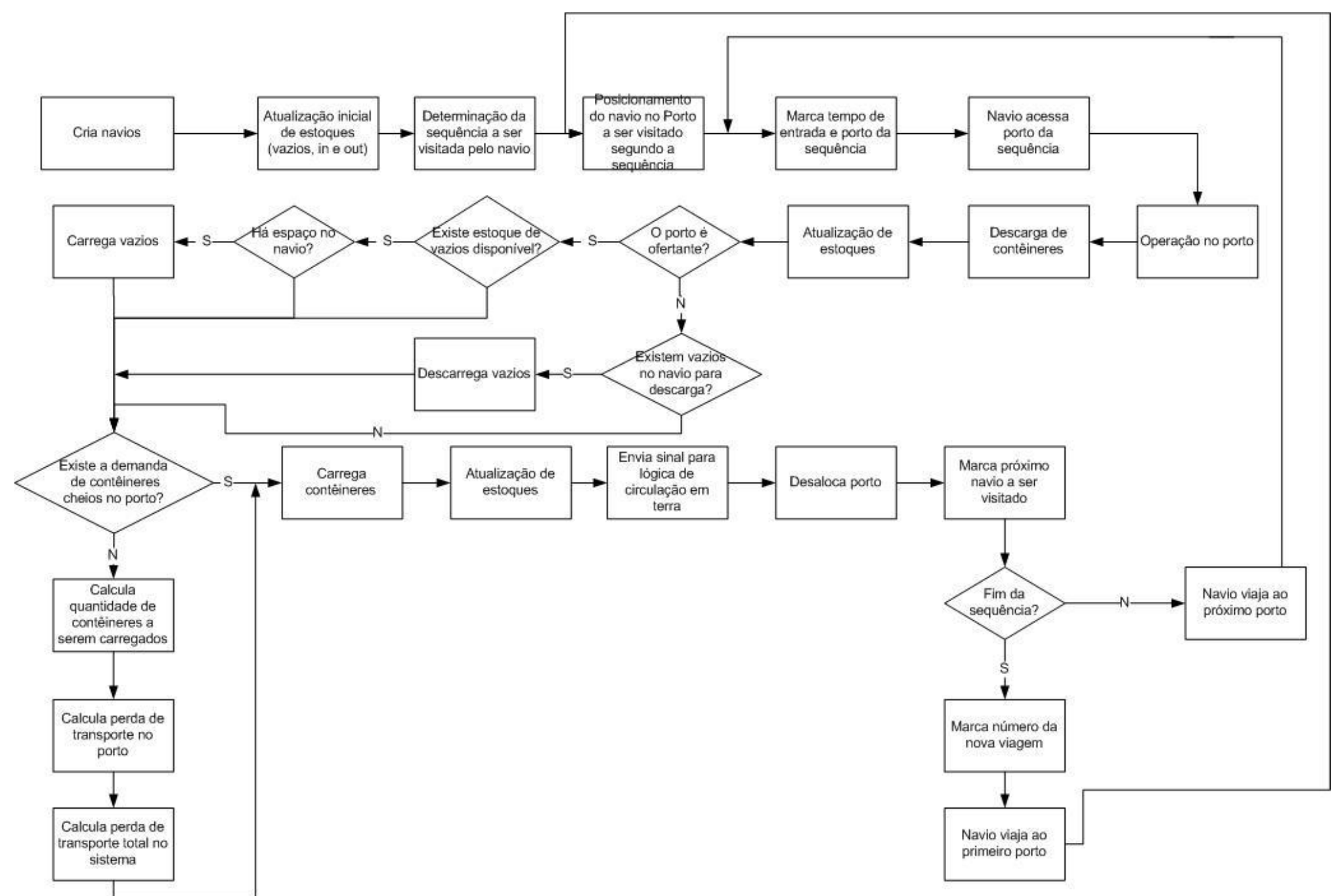

Figura 4-4: Modelo conceitual da lógica de circulação de navios entre os portos 
A segunda etapa do modelo de simulação proposto representa a circulação de contêineres em terra. As regras adotadas para a implementação desta lógica no modelo são:

- Os contêineres cheios que são descarregados dos navios ao longo do tempo são despachados para os clientes seguindo uma distribuição triangular de tempo de permanência que inclui: viagem ao cliente, esvaziamento e retorno para o estoque de contêineres vazios junto ao porto;

- Diariamente, é sorteada uma demanda de contêineres vazios necessária para atender aos clientes de exportação na região de influência de cada porto. O estoque de contêineres vazios é verificado e envia-se aos clientes o total solicitado ou o que estiver disponível, zerando, neste caso o estoque de vazios no porto;

- Adotou-se que o saldo de contêineres vazios, não atendido, é acumulado para o dia seguinte;

- O tempo de permanência dos contêineres vazios, que segue uma distribuição triangular, inclui viagem, carregamento e retorno ao porto para ser somado ao estoque de contêineres cheios, que estão disponíveis para serem carregados nos navios (contêineres "out").

Cabe ressaltar que é o balanço de contêineres cheios e vazios nos portos que permite $o$ atendimento aos clientes em terra que necessitam de contêineres vazios e o atendimento dos navios que passam em cada porto, e necessitam ser carregados de acordo com a matriz de carga pré-definida.

O fluxograma que representa a modelagem conceitual desta lógica é apresentado na Figura 4-5. 


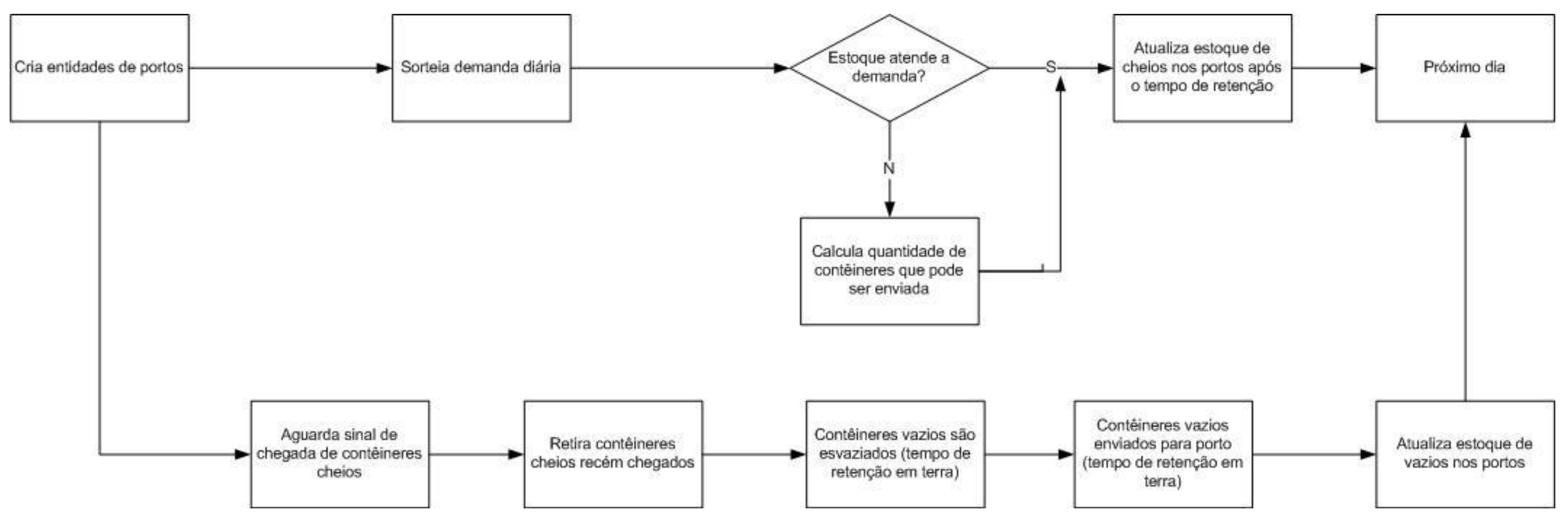

Figura 4-5: Modelo conceitual da lógica de circulação de contêineres em terra 
Os modelos conceituais aqui apresentados serviram como base para a codificação do modelo de simulação construído, garantindo que a lógica considerada contenha todos os eventos existentes e que estes sigam a sequência adequada, possibilitando a futura validação do modelo.

\subsection{INTERFACE DE ENTRADA DE DADOS}

Para que os cenários sejam configurados de forma rápida e fácil foi criada uma interface de entrada de dados, utilizada como apoio ao modelo de simulação.

Esta interface de entrada de dados foi construída no ambiente de planilha eletrônica do Microsoft Exce|® e sua utilização é fácil e intuitiva, permitindo que sejam construídos os mais diferentes cenários e realize as mais diversas análises.

As informações que devem ser alteradas na interface para configuração de diferentes cenários são:

- Quantidade de navios que compõem a frota utilizada: neste campo, o é definida a quantidade de navios que a empresa de navegação utiliza para transportar contêineres. Este valor deve ser de, no máximo, 20 navios. Deve-se ter em mente que, ao modificar o tamanho da frota de navios, automaticamente será modificada a demanda de contêineres nos portos, uma vez que tais demandas são determinadas pelas matrizes de cargas específicas de cada um;

- Quantidade de portos considerados na rota analisada: para estabelecer a quantidade de portos que devem ser visitados pela frota de navios disponível, deve-se preencher um campo da interface de entrada de dados. As rotas podem ser compostas por até 20 portos diferentes;

- Sequência de viagem de navios: em uma matriz com 20 linhas e 20 colunas, devem ser configuradas as rotas que são seguidas por cada navio da frota. Cada linha representa um dos possíveis 20 navios utilizados, e as colunas devem ser preenchidas com os números dos portos a serem visitados, na sequência em que as visitas acontecem, 
considerando até 20 portos possíveis em uma rota. Por exemplo, se um navio visita o porto 13 , vai para o porto 5 e retorna para o porto 13 , as três primeiras sequências (colunas) do navio devem ser os números 13, 5 e o 13 novamente. A sequência limita o numero de portos visitados em uma rota a até 20 portos e deve considerar o retorno dos navios. A Figura 4-6 apresenta uma amostra desta matriz;

\begin{tabular}{|c|c|c|c|c|c|c|c|c|}
\hline $\begin{array}{l}\text { Sequência de } \\
\text { viagens dos navios }\end{array}$ & SEQUENCIA 1 & SEQUENCIA 2 & SEQUENCIA 3 & SEQUENCIA 4 & SEQUENCIA 5 & SEQUENCIA 6 & SEQUENCIA 7 & SEQUENCIA 8 \\
\hline Navio 1 & 1,00 & 2,00 & 3,00 & 4,00 & 3,00 & 2,00 & 1,00 & - \\
\hline Navio 2 & 1,00 & 2,00 & 3,00 & 2,00 & 1,00 & - & - & - \\
\hline Navio 3 & 1,00 & 3,00 & 4,00 & 3,00 & 1,00 & - & - & - \\
\hline Navio 4 & 1,00 & 4,00 & 1,00 & - & - & - & - & - \\
\hline Navio 5 & - & - & - & - & - & - & - & - \\
\hline Navio 6 & - & - & - & - & - & - & - & - \\
\hline Navio 7 & - & - & - & - & - & - & - & - \\
\hline
\end{tabular}

Figura 4-6: Amostra da interface de entrada de dados - inserção das sequências de visitas dos portos pelos navios

- Estoque inicial de contêineres vazios nos portos: deve ser inserida a quantidade de contêineres vazios que compõem o estoque inicial dos portos. A entrada de dados deve ser feita em uma tabela com 20 colunas, na qual cada uma das colunas representa um dos possíveis portos existentes;

- Estoque inicial de contêineres cheios nos portos à disposição para serem retirados pelos clientes (in): deve ser inserida a quantidade inicial de contêineres cheios que estarão nos portos e deverão ser encaminhados aos clientes. Tal entrada de dados é realizada em uma tabela de uma linha e 20 colunas;

- Estoque inicial de contêineres cheios nos portos à disposição para serem retirados pelos navios (out): deve ser inserida a quantidade inicial de contêineres cheios que estarão nos portos e deverão ser carregados nos navios. Tal entrada de dados é realizada em uma tabela de uma linha e 20 colunas;

- Matriz de cargas: em uma aba diferente, devem ser preenchidas as matrizes de carga programadas para cada navio. Estes valores serão atribuídos no instante inicial para cada navio da frota nas posições em que são inseridas. São matrizes com 20 linhas e 20 colunas cujas 
células representam a quantidade de contêineres que serão transportadas de um porto para outro através do navio representado. Se a célula que representa a linha 12 e a coluna 5 estiver preenchida com 0 valor 40 , significa que 40 contêineres devem ser transportados do porto 12 para o porto 5 a cada viagem do navio em questão. Em todas as viagens de um dado navio deve ser considerada a mesma matriz. É a partir das matrizes de cargas que as demandas e desequilíbrios entre os portos são verificadas;

- Velocidade dos navios (nós): neste campo, deve ser preenchida a velocidade média dos navios utilizados na simulação. Esta velocidade deve ser utilizada em nós, e a própria interface converterá em $\mathrm{km} / \mathrm{h}$. Quanto maior a velocidade, mais ciclos poderão ser realizados e maior será a demanda carregada nos portos, sendo assim, nota-se a importante relação que a velocidade tem com a quantidade de contêineres carregada e descarregada nos terminais;

- Distância entre portos $(\mathrm{km})$ : em uma matriz de 20 linhas e 20 colunas, 0 devem ser preenchidas as distâncias entre os portos considerados na rota simulada. Tal distância é preenchida em $\mathrm{km}$ e a interface criará outra matriz, com os tempos médios de viagens, em horas, entre os portos das rotas, que será lida pelo modelo de simulação para representar os intervalos entre as visitas aos portos. A Figura 4-7 apresenta uma amostra dessa matriz de distância entre os portos;

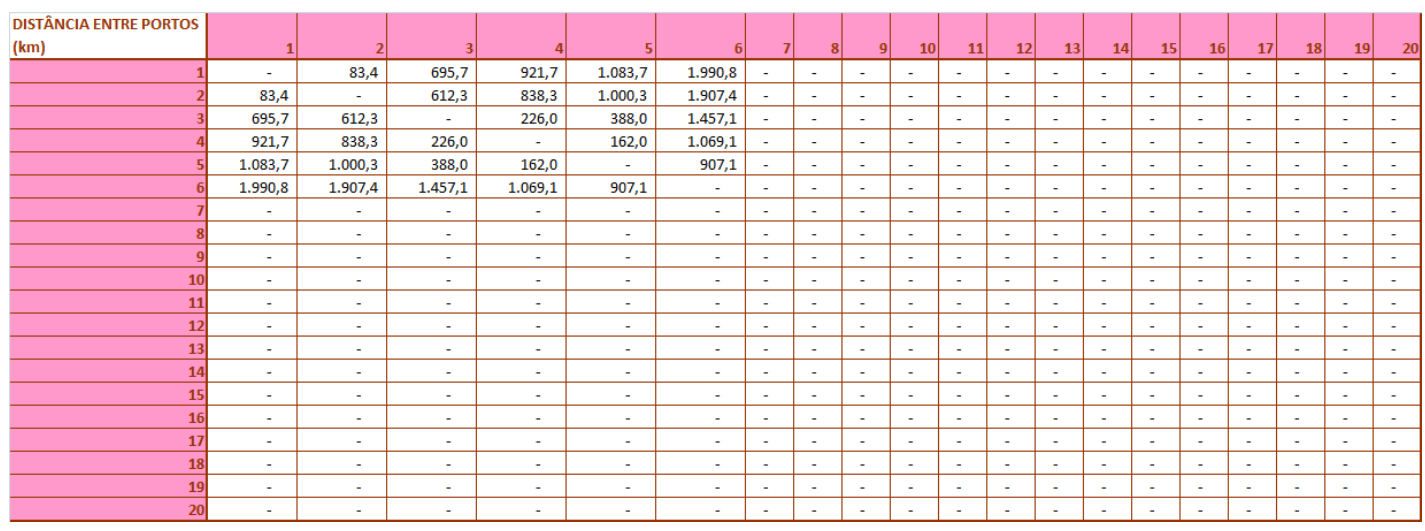

Figura 4-7: Amostra da interface de entrada de dados - inserção das distâncias entre os portos 
- Tempo médio de permanência nos portos (h): Nesta tabela com 20 células para preenchimento (uma coluna), deve ser inserida a duração média de operação dos navios nos portos considerados. Esse intervalo médio deve considerar toda a alocação do terminal, incluindo atracação, operações de carga e descarga e desatracação;

- Capacidade de contêineres dos navios: tal informação é muito importante, pois, através dela o modelo calcula a quantidade de contêineres que podem ser reposicionados;

- Necessidade média diária por contêineres vazios: a interface deve ser preenchida com a quantidade média, diária, de contêineres vazios demandada por cada porto, e o modelo considerará uma distribuição triangular a partir deste valor médio. Os valores inseridos em cada uma das 20 linhas desta tabela devem ser preenchidos após uma simulação com a matriz de carga a ser utilizada, na qual é obtida a demanda anual por contêineres cheios nos portos e calculadas as quantidades diárias necessárias. Repare que, caso sejam alteradas as matrizes de carga, as quantidades de navios e ou a velocidade das embarcações, o valor a ser inserido neste campo será modificado, necessitando de uma nova rodada de simulação para obtenção dos novos valores;

- Chegada média diária de contêineres: deve-se preencher a interface com a quantidade média, diária, de contêineres que são entregues por dia no porto, e o modelo considerará uma distribuição triangular a partir deste valor médio. Os valores inseridos em cada uma das 20 linhas desta tabela devem ser preenchidos após uma simulação com a matriz de carga a ser utilizada, na qual é obtida a demanda anual por contêineres cheios nos portos e calculadas as quantidades diárias que são descarregadas. Da mesma forma que a demanda média diária por contêineres vazios, os valores devem ser modificados caso haja alteração de alguns parâmetros que alterem a demanda nos portos;

- Tempo de retenção de contêineres em terra: em outra tabela com 20 linhas (uma para cada possível porto da rota), deve-se informar ao modelo o tempo médio de retenção dos contêineres em terra, e o modelo considerará uma distribuição triangular a partir deste valor médio. Esse tempo médio representa o período de tempo que 
compreende 0 envio de contêineres cheios para os clientes, o esvaziamento e a devolução destes, vazios, aos depósitos portuários ou o envio de contêineres cheios e o carregamento nos clientes (atualização do estoque de vazios);

- Log de navios: em uma última aba presente no arquivo de interface de entrada de dados para a simulação, existe um log gerado ao fim de cada simulação, e registrado na planilha em Excel. Nesse log, pode-se verificar detalhadamente todas as atualizações de estoques que ocorrem nos portos ao longo de todas as viagens realizadas, por todos os navios, e verificar a quantidade de contêineres reposicionados. Através de uma análise das informações contidas neste log é possível determinar em qual dos portos houve perdas de transporte por falta de contêineres vazios e determinar em qual porto os estoques devem ser incrementados para diminuir possíveis perdas de transporte. Este log foi muito útil para a validação do modelo de simulação, pois a partir dele foi possível verificar se as matrizes de carga inseridas eram seguidas pelo modelo e se as sequências de carregamento (e descarregamento), respeitadas.

Além destes dados preenchidos diretamente, a planilha executa ainda alguns cálculos e informações que também serão utilizadas na simulação, tais como a determinação, a partir das matrizes de cargas dos navios, de quais portos são ofertantes e quais portos são demandantes, além das porcentagens de vazios que devem ser reposicionadas, determinadas pela sequência definida.

4.4.1. Utilizando a interface de entrada de dados e o modelo para construção de cenários e análises de sensibilidade

A interface de dados deve ser utilizada para construir os cenários desejados e preparar o modelo para analisar o comportamento do sistema em função da variação de alguns parâmetros. 
Considerando que o principal objetivo deste trabalho é dimensionar eficientemente a frota de contêineres nos terminais portuários, deve-se entender o mecanismo de análise do estoque, a fim de se construir cenários bases para a simulação de cenários derivados e análises de sensibilidade.

Em um primeiro momento, deve-se utilizar a interface de entrada de dados para informar os estoques iniciais de contêineres vazios, contêineres cheios in e contêineres cheios out. Considera-se que a soma de todos esses estoques iniciais é a frota de contêineres da empresa, visto que existe balanço de massa e não há inserção ou exclusão de recipientes durante a simulação. A Figura 4-8 apresenta a tabela da interface em que são configurados os estoques iniciais em cada porto.

\begin{tabular}{|l|l|l|l|l|l|l|l|}
\cline { 3 - 9 } 28 & & Porto 1 & Porto 2 & Porto 3 & Porto 4 & Porto 5 & Porto 6 \\
\hline 29 & Estoque de conteineres vazios nos portos & 9000 & 4800 & 4200 & 3000 & 4800 & 8400 \\
\hline 30 & Estoque de conteineres cheios nos portos (in) & 9000 & 4800 & 4200 & 3000 & 4800 & 8400 \\
\hline 31 & Estoque de conteineres cheios nos portos (out) & 9000 & 4800 & 4200 & 3000 & 4800 & 8400 \\
\hline
\end{tabular}

Figura 4-8: Amostra da interface de entrada de dados - inserção dos estoques iniciais (valores fictícios) em cada porto

Inseridos todos os dados de entrada, e configuradas as quantidades médias diárias de contêineres descarregados e demandados em cada porto, é realizada a simulação do cenário construído. Ao final da simulação, o primeiro resultado verificado é a perda de transporte nos portos, ou seja, a quantidade de contêineres que não foi entregue por falta de vazios nos terminais. Primeiramente, adota-se a condição de que tal perda deve ser igual a zero, 0 que fará com que os estoques iniciais de contêineres possam ter quantidades elevadas de contêineres.

Para que seja determinada uma quantidade mínima de contêineres nos estoques iniciais (minimização da frota de contêineres), pode-se utilizar uma ferramenta de busca da melhor solução e estabelecer uma função objetivo a ser minimizada, que garanta um balanço entre a minimização do estoque e da perda de transportes, ponderando-as. 
Com os estoques iniciais determinados, pode-se partir para outras análises. Dentre as análises possíveis de serem realizadas, destacam-se a alteração do tempo médio de retenção dos contêineres em terra e a variação da demanda a ser transportada, através da velocidade dos navios, das matrizes de carga utilizadas e até da alteração do tamanho da frota.

Através da interface, pode-se variar a velocidade dos navios e fazer com que o número de viagens redondas das embarcações seja alterado, modificando assim a demanda a ser atendida pelo sistema.

Ao variar a velocidade das embarcações, deve-se executar uma simulação de um ano para verificar qual deveria ser a demanda embarcada e descarregada anualmente em cada porto (resultados exibidos ao final das simulações). Com estes valores, são inseridos na interface as quantidades médias diárias de contêineres descarregados em cada porto e a demanda média diária por contêineres vazios em todos eles. Feito isso, o cenário que analisa a demanda modificada pode ser simulado.

Este procedimento deve ser realizado, também, caso haja alteração nas matrizes de cargas e no tamanho da frota de porta-contêineres, pois são modificações que causam como principal efeito a variação da demanda anual a ser atendida.

Através da interface de entrada de dados também pode ser variado o tempo médio de retenção dos contêineres em terra para que se verifique o comportamento do sistema quando este parâmetro for variado e sua influência na necessidade de se dispor de mais contêineres nos portos.

Outra análise muito importante e que também deve ser realizada é a verificação do sistema em face da não realização do reposicionamento de vazios entre os portos. Para isso, basta que o modelo seja alterado, zerando-se a quantidade máxima de vazios a bordo.

Cabe ressaltar que em todos estes cenários de análise de sensibilidade, o enfoque deve ser mantido na verificação do comportamento dos estoques iniciais (frota de contêineres) e nas perdas de transporte, pois estas são as principais respostas obtidas com o modelo construído. 


\section{APLICAÇÃO DO MODELO DE SIMULAÇÃO E OS RESULTADOS OBTIDOS}

Neste capítulo são apresentadas as principais análises e os resultados obtidos com o modelo de simulação da movimentação de contêineres (cheios e vazios) por navios em rotas pré-determinadas e ciclo fechado.

Inicialmente, são apresentadas algumas informações utilizadas como parâmetros de entrada do modelo (dados fornecidos por uma empresa de navegação).

Será apresentada, também, uma ferramenta de busca de soluções próximas da ótima utilizada para determinação da frota de contêineres com a qual deve contar a companhia de navegação (dimensionamento da frota). Essa é uma das principais contribuições deste trabalho, pois esta ferramenta é prática e proporciona grande apoio às decisões de planejamento da companhia de navegação, podendo ser utilizada, também para avaliar projeções de demanda e os índices de operação nos terminais. Feito isso, será definido o cenário base e, a partir deste, realizadas algumas análises de sensibilidade consideradas relevantes.

É importante que se destaque que o período considerado para as simulações foi de um ano. Considerando que uma empresa de navegação, em geral, trabalha com planejamentos de 6 meses (para trabalhar com a mesma matriz de carga), adotou-se esse período de um ano, replicado cinco vezes, para que se obtivesse a estabilidade das principais respostas do modelo e garantir que as respostas obtidas possam ser consideradas válidas e utilizadas para 0 planejamento a ser executado. 


\subsection{DADOS DE ENTRADA PARA O CENÁRIO BASE}

Para a construção de um cenário base, ponto de partida para análises de sensibilidade e validação do modelo de simulação, foram solicitados dados para uma grande companhia de navegação que atua no Brasil, cuja identificação será mantida em sigilo a pedido da empresa. As demandas utilizadas, e aqui apresentadas, foram multiplicadas por um fator de conversão para serem ajustadas e, dessa forma, permanecerem em sigilo, mantendo-se as mesmas ordens de grandeza e possibilitando a análise realista dos resultados obtidos.

O banco de dados fornecido pela companhia de navegação foi analisado e dele foram extraídas as informações necessárias para a construção de um cenário inicial de simulação.

Os dados escolhidos compõem informações de uma rota de cabotagem na qual os navios visitam 6 portos da costa brasileira: Santos (SSZ), Sepetiba (Itaguaí) (SPB), Suape (SUA), Fortaleza (FOR), Pecém (PEC) e Manaus (MAO). Para facilitar a leitura dos dados pelo modelo, os portos foram numerados e todas as respectivas informações se referem ao número correspondente. A numeração adotada foi:

- Porto 1: SSZ (Santos);

- Porto 2: SPB (Sepetiba-Itaguaí);

- Porto 3: SUA (Suape);

- Porto 4: FOR (Fortaleza);

- Porto 5: PEC (Pecém);

- Porto 6: MAO (Manaus).

Esta rota foi informada pela empresa de navegação. A Figura 5-1 mostra a localização destes portos. 


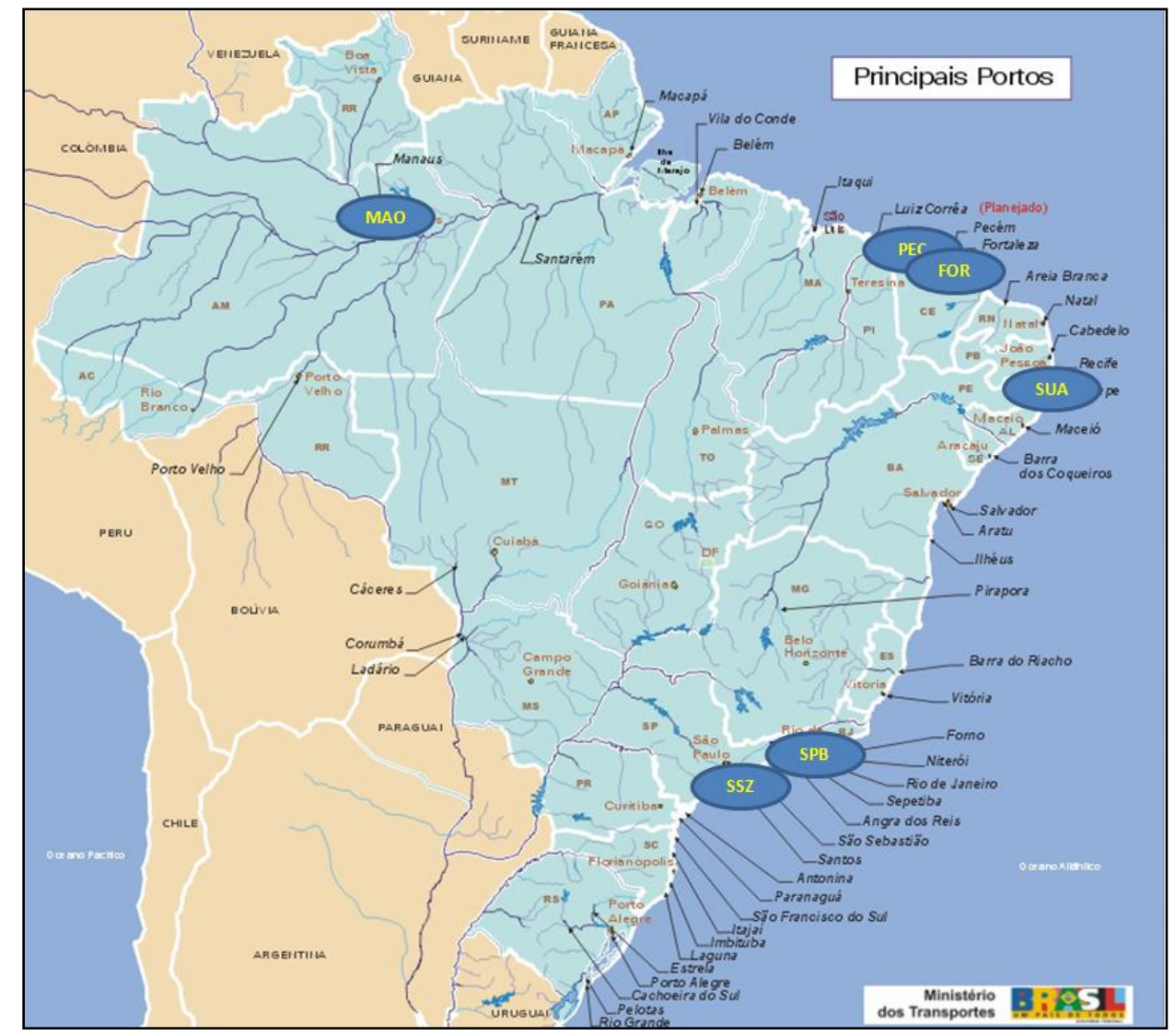

Figura 5-1: Localização dos portos da rota na costa brasileira. FONTE: Ministério dos Transportes

Dentre os dados fornecidos pela empresa, estão as demandas de contêineres cheios que existe entre os portos visitados. Tais informações foram tratadas e obtiveram-se, então, as matrizes de cargas, consideradas iguais para todos os navios. Nesta matriz de cargas, encontram-se as quantidades de contêineres cheios que devem ser retirados de um porto com destino a cada um dos outros que compõem a rota, em cada viagem. A matriz de carga, para cada navio, é a desejada pela empresa de navegação para manter a rentabilidade da mesma dentro de níveis especificados para esse tipo de empreendimento de transportes.

Dessa maneira, o modelo de simulação proposto busca determinar qual a frota de contêineres necessária para atender a essa matriz de carga desejada pela empresa. Na realidade, esse transporte está sujeito a variações de demanda, que pode superar ou não a matriz de carga mínima desejada. 
Uma vez conhecida a matriz de carga desejada, como era esperado, é apresentado um "imbalance" entre os portos. Assim, calculam-se quais são os portos ofertantes e quais são os demandantes por contêineres vazios.

A matriz de cargas considerada pelos navios é apresentada na Tabela 5-1.

\begin{tabular}{|l|l|c|c|c|c|c|c|}
\multicolumn{1}{c|}{} & \begin{tabular}{c} 
Tabela 5-1: Matriz de cargas dos navios - cenário base inicial \\
\cline { 2 - 7 }
\end{tabular} & $\begin{array}{c}\text { PORTO } \\
\mathbf{1}\end{array}$ & $\begin{array}{c}\text { PORTO } \\
\mathbf{2}\end{array}$ & $\begin{array}{c}\text { PORTO } \\
\mathbf{3}\end{array}$ & $\begin{array}{c}\text { PORTO } \\
\mathbf{4}\end{array}$ & $\begin{array}{c}\text { PORTO } \\
\mathbf{5}\end{array}$ & $\begin{array}{c}\text { PORTO } \\
\mathbf{6}\end{array}$ \\
\hline PORTO 1 & 0 & 7 & 503 & 39 & 303 & 332 \\
\hline PORTO 2 & 15 & 0 & 221 & 9 & 51 & 300 \\
\hline PORTO 3 & 61 & 10 & 0 & 5 & 9 & 400 \\
\hline PORTO 4 & 20 & 11 & 100 & 0 & 5 & 18 \\
\hline PORTO 5 & 128 & 15 & 273 & 50 & 0 & 299 \\
\hline PORTO 6 & 1388 & 177 & 206 & 12 & 35 & 0 \\
\hline
\end{tabular}

Cabe destacar, ao observar a Tabela 5-1, a grande quantidade de contêineres que seguem do porto 6 para o porto 1 , bem como a grande quantidade de contêineres que são descarregados no porto 6 .

Ao preencher as matrizes de carga, obtém-se, também, os saldos de contêineres vazios nos portos, reproduzidos na Figura 5-2. Com isso, o modelo utilizará as proporções calculadas para determinar a quantidade de contêineres vazios que deveriam ser retirados dos portos ofertantes e quantos seriam descarregados em cada porto da sequência. 
Sequência de Portos: 1 - 2 - 3 - 5 - 6 - 4

\begin{tabular}{|c|c|c|}
\hline \multirow[b]{2}{*}{ Porto 1} & Saldo & \multirow{7}{*}{$\begin{array}{l}\text { ofertante } \\
\text { demandante } \\
\text { ofertante } \\
\text { demandante } \\
\text { demandante } \\
\text { demandante }\end{array}$} \\
\hline & 428 & \\
\hline Porto 2 & -376 & \\
\hline Porto 3 & 818 & \\
\hline Porto 4 & -39 & \\
\hline Porto 5 & -362 & \\
\hline Porto 6 & -469 & \\
\hline
\end{tabular}

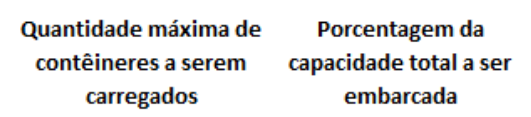

Porcentagem da

capacidade total a ser descarregada

Figura 5-2: Representação do mecanismo de reposicionamento de contêineres vazios

Foram considerados, para a rota simulada, 4 navios idênticos, em uma rota projetada para a velocidade de 15 nós.

A capacidade destes navios (3.500 TEU's) é suficiente para transportar os contêineres cheios e reposicionar os contêineres vazios.

A Figura 5-3 apresenta as quantidades de contêineres cheios a bordo em cada trecho do ciclo de viagens. Repare que a quantidade máxima de cheios a bordo é de 2.462 contêineres, o que permite, ainda, que se tenha 1.038 contêineres vazios no mesmo navio.

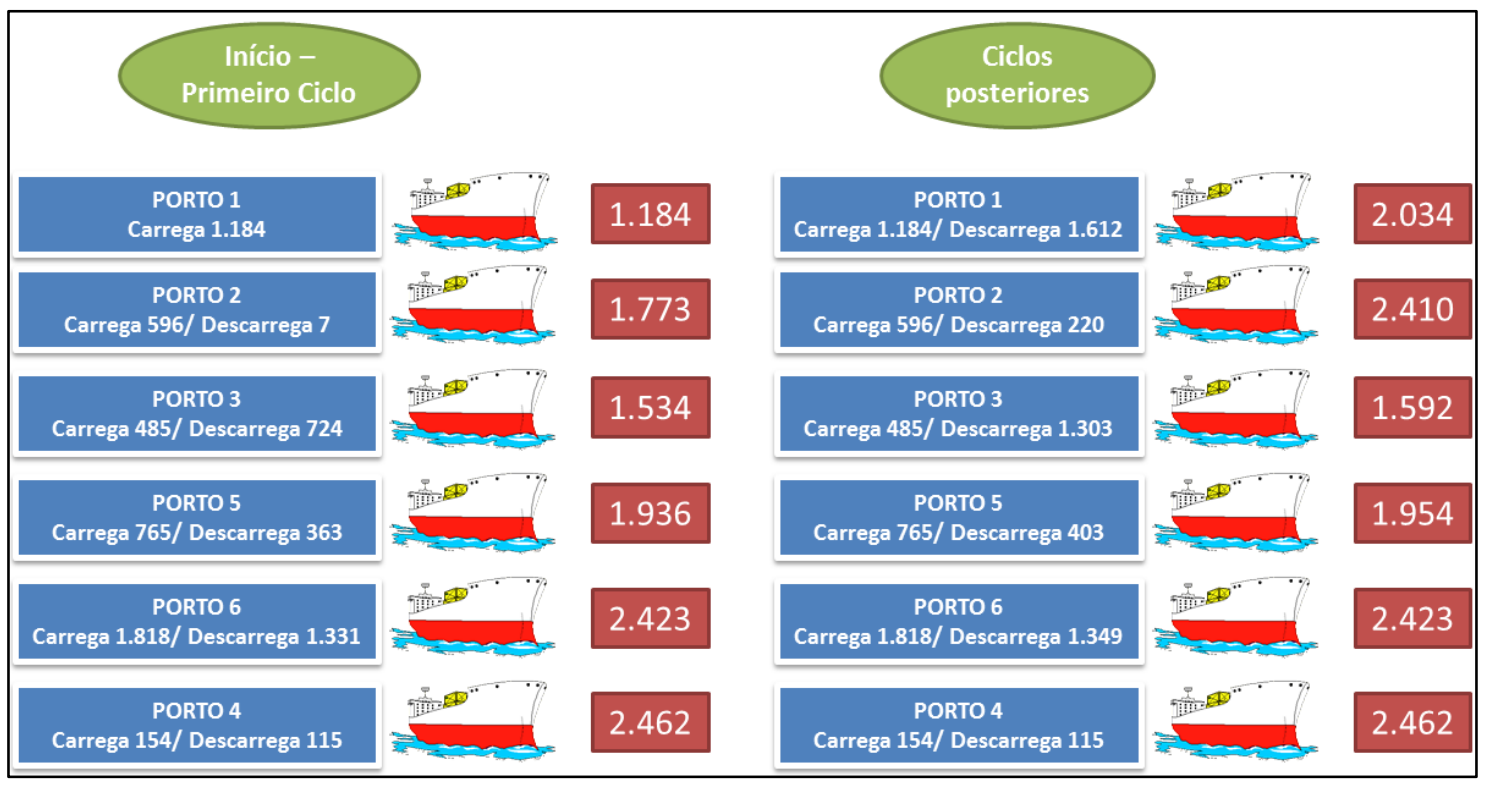

Figura 5-3: Quantidades de contêineres cheios a bordo em cada trecho do ciclo de viagens 
A sequência de visitas aos portos é a mesma para os quatro navios da frota:

- Sequência de visitas: porto 1 - porto 2 - porto 3 - porto 5 - porto 6 porto 4.

Destaca-se que, ao final da sequência, todos os navios devem voltar para 0 porto inicial e repetir o ciclo. A Figura 5-4 ilustra o ciclo básico de viagem dos navios na rota considerada.

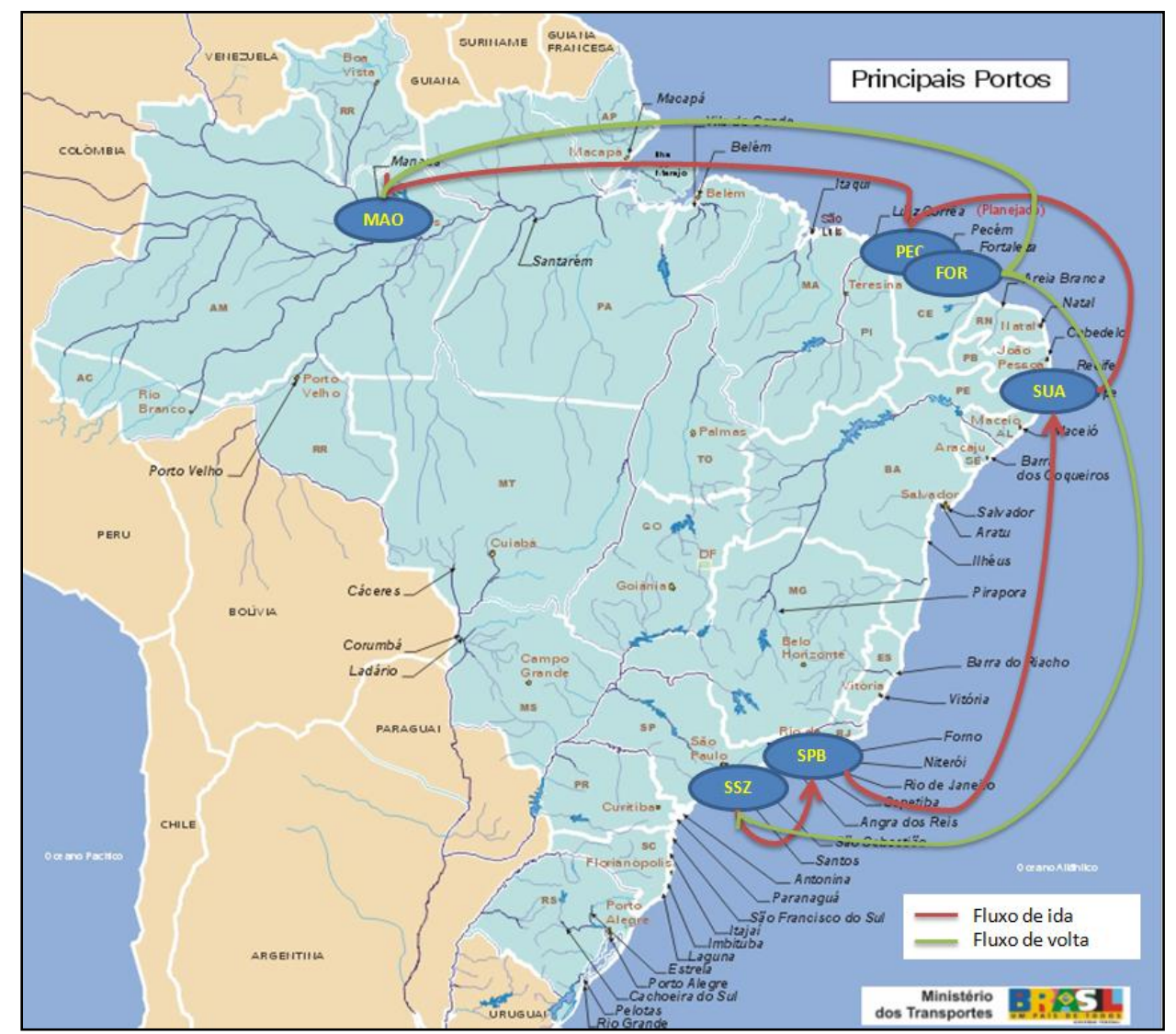

Figura 5-4: Representação da rota seguida pelos navios

Sendo a velocidade dos navios igual a 15 nós $(27,8 \mathrm{~km} / \mathrm{h})$, através da matriz de distâncias entre os portos são obtidas as durações das viagens entre os mesmos. A Tabela 5-2 mostra as distâncias, em quilômetros, entre os 6 portos considerados nas rotas dos navios. 
Tabela 5-2: Matriz de distância entre os portos considerados

\begin{tabular}{|l|l|l|l|l|l|l|}
\cline { 2 - 7 } \multicolumn{1}{c|}{} & PORTO 1 & PORTO 2 & PORTO 3 & PORTO 4 & PORTO 5 & PORTO 6 \\
\hline PORTO 1 & 0 & $83,4 \mathrm{~km}$ & $695,7 \mathrm{~km}$ & $921,7 \mathrm{~km}$ & $1083,7 \mathrm{~km}$ & $1990,8 \mathrm{~km}$ \\
\hline PORTO 2 & $83,4 \mathrm{~km}$ & 0 & $612,3 \mathrm{~km}$ & $838,3 \mathrm{~km}$ & $1000,3 \mathrm{~km}$ & $1907,4 \mathrm{~km}$ \\
\hline PORTO 3 & $695,7 \mathrm{~km}$ & $612,3 \mathrm{~km}$ & 0 & $226,0 \mathrm{~km}$ & $388,0 \mathrm{~km}$ & $1457,1 \mathrm{~km}$ \\
\hline PORTO 4 & $921,7 \mathrm{~km}$ & $838,3 \mathrm{~km}$ & $226,0 \mathrm{~km}$ & 0 & $162,0 \mathrm{~km}$ & $1069,1 \mathrm{~km}$ \\
\hline PORTO 5 & $1083,7 \mathrm{~km}$ & $1000,3 \mathrm{~km}$ & $388,0 \mathrm{~km}$ & $162,0 \mathrm{~km}$ & 0 & $907,1 \mathrm{~km}$ \\
\hline PORTO 6 & $1990,8 \mathrm{~km}$ & $1907,4 \mathrm{~km}$ & $1457,1 \mathrm{~km}$ & $1069,1 \mathrm{~km}$ & $907,1 \mathrm{~km}$ & 0 \\
\hline
\end{tabular}

Outros dados informados pela companhia de navegação remetem à produtividade nos portos considerados. É considerada a duração média das operações dos contêineres em cada porto, considerando a atracação e a desatracação das embarcações. Para estes valores, utiliza-se uma distribuição estatística triangular (com variação de 30\% em relação à média, ou seja, o menor valor é 30\% menor que a média e o maior valor, 30\% maior que esta mesma média) que, segundo a empresa que forneceu os dados, adere aos dados reais. Os valores médios adotados foram:

- Porto 1: 14 horas;

- Porto 2: 30 horas;

- Porto 3: 48 horas;

- Porto 4: 50 horas;

- Porto 5: 48 horas;

- Porto 6: 30 horas.

Estes valores representam o tempo total da operação desde a atracação até a partida de cada navio, e engloba carregamento e descarregamento de contêineres. É possível notar que a eficiência no porto 1 (SSZ - Santos) é maior que a eficiência dos outros terminais de contêineres, sendo que a operação leva menos da metade do tempo que leva nos portos 2 e 6 , por exemplo.

Como citado no capítulo 4, para atender à matriz de carga de contêineres cheios que cada navio deve retirar de cada porto, haverá a geração diária da necessidade de contêineres vazios compatível com essa matriz, que serão 
enviados para os clientes a fim de serem carregados. Esses contêineres retornarão ao porto após um período de retenção e, em princípio, não devem provocar um aumento contínuo do estoque de contêineres cheios disponíveis para os navios. Esse, portanto, é um princípio de equilíbrio de fluxo de contêineres no sistema.

Por outro lado, à medida que os contêineres vão sendo descarregados nos portos, eles vão sendo remetidos aos clientes e, depois de um tempo de retenção, devolvidos ao estoque de contêineres vazios. Se for um porto ofertante de contêineres vazios, esse valor será suficiente para atender aos clientes da região conforme mencionado acima e o saldo de vazios ser despachado para os portos demandantes da rota.

Isso deve ser configurado diretamente no modelo, com uma variável que determina a demanda média diária dos clientes por contêineres vazios (que retornarão cheios) nos portos.

A empresa também forneceu o tempo médio de retenção dos contêineres em terra. Trata-se do tempo que um contêiner leva desde o momento em que é enviado ao cliente (seja para carregar ou ser descarregado) até o instante em que retorna ao terminal portuário (vazio ou cheio). Esse tempo de retenção incorpora carregamento, descarregamento e transporte dos contêineres, além de possíveis atrasos devido a processos alfandegários, limpeza e inspeção destes contêineres.

O tempo médio de retenção utilizado foi de 15 dias, também considerando a distribuição estatística triangular com variação de $30 \%$, de acordo com 0 informado pela empresa de navegação.

Os estoques iniciais de contêineres cheios e vazios nos portos são, como apresentado no capítulo 4, as variáveis de decisão do problema de busca da melhor solução (minimização da frota de contêineres), pois se referem ao tamanho da frota de contêineres da empresa de navegação, necessária para atendimento da matriz de carga. $\mathrm{Na}$ interface, deve ser preenchido, para cada porto, no início da simulação, a quantidade de contêineres cheios que podem ser despachados para os clientes em terra para serem esvaziados, a quantidade de contêineres vazios e a quantidade de contêineres cheios que 
devem ser retirados pelo próximo navio que visitar o porto. Cabe ressaltar que a soma destes estoques em cada porto e, na soma de todos os portos, é a frota necessária de contêineres para atender à matriz de carga desejada. Foi necessário dividir o estoque total, em cada porto, nesses três estoques iniciais (cheios "in", cheios "out" e vazios), para que a simulação não tivesse um longo período transitório até obter um equilíbrio.

Esse estoque inicial total de contêineres compõe uma parte da função objetivo que se deseja minimizar. Uma função objetivo é uma equação presente em problemas de otimização para representar o foco do problema como, por exemplo, a minimização de custos ou a maximização de lucros.

A outra parte desta função a ser considerada é a perda de transporte pelos navios por falta de contêineres cheios disponíveis no porto ao longo do tempo e falta de contêineres vazios que causa o não atendimento do carregamento da carga para um dado navio (não atendimento da matriz de carga em cada visita de um navio a um porto).

Em outras palavras, busca-se uma frota de contêineres que atenda à matriz de carga desejada para cada um dos navios da frota. Em princípio, a perda de carga (não atendimento da matriz de carga) deveria ser zero e a frota de contêineres, a menor possível.

Poderia haver situações em que uma perda de transporte fosse suprida por aluguel de contêineres ("leasing") por viagem, de tal forma que a frota necessária de contêineres fosse ainda menor. Porém, essa opção não foi implementada no modelo de simulação por aumentar a complexidade do problema e gerar a necessidade de informações não fornecidas pela companhia de navegação. 


\subsection{INDICADORES FORNECIDOS PELO MODELO DE SIMULAÇÃO}

As respostas obtidas a cada processamento do modelo de simulação são:

- Função objetivo: soma de estoque inicial de contêineres inseridos no modelo mais a quantidade de contêineres não embarcados (demanda não atendida) ao longo do tempo. Como se busca a otimização, ou a melhor solução, das respostas obtidas, cabe a utilização do termo "função objetivo" neste estudo de simulação;

- Balanço de massa de contêineres movimentados para cada porto: demandas de contêineres cheios e vazios que são carregados e descarregados dos navios e a quantidade de contêineres que circulam em terra;

- Estoques de contêineres cheios (in e out) e vazios em todos os portos;

- Quantidade de contêineres reposicionados (demandantes e ofertantes);

- Indicadores operacionais: tempo de ciclo dos navios, tempo de permanência dos navios nos portos, quantidade de ciclos de cada embarcação.

Destes resultados, destaca-se a perda de transporte (matriz de carga não atendida), um dos fatores que compõem a função objetivo a ser minimizada através de uma quantidade adequada de contêineres em estoque inicial (frota de contêineres). Dessa maneira, portanto, alterando-se os estoques iniciais de cheios e vazios nos portos, é possível avaliar o comportamento da função objetivo que se deseja minimizar.

A interface em Excel® também é utilizada para apresentar outros resultados obtidos com as simulações dos diferentes cenários. Através de uma planilha chamada "Log de navios", é possível mapear completamente todas as viagens e operações realizadas por cada um dos navios, incluindo instantes das operações, quantidades de contêineres carregados e descarregados a cada parada de cada navio e estoques nos portos. Essa aba permite a extração de diversos resultados e possibilita a criação de estatísticas que ajudam a 
interpretar os resultados, auxiliam na comparação entre os cenários e validar o modelo de simulação.

Também é possível verificar o comportamento dos estoques a cada viagem e analisar o funcionamento do modelo, certificando-se que as sequências seguidas por cada navio conferem com as que foram inseridas na interface de entrada de dados.

\subsection{RESULTADOS DA SIMULAÇÃO: PROCESSAMENTO INICIAL A PARTIR DE ESTOQUE SUFICIENTE PARA ATENDER À DEMANDA INTEGRALMENTE}

Este primeiro cenário simulado é o ponto de partida para a simulação dos cenários de busca pelo dimensionamento da frota de contêineres e posteriores análises de sensibilidade em função de parâmetros importantes.

O cenário inicial é construído a partir dos dados de entrada e premissas apresentadas na seção 5.1 , representando uma operação regular de todo o sistema que inclui os seis portos da rota e os quatro navios.

Como citado anteriormente, os estoques iniciais de contêineres são as variáveis de decisão que atendem ao objetivo deste trabalho, que é dimensionar a frota de contêineres da empresa de navegação. Processando-se o modelo com diferentes níveis de estoque inicial nos portos, busca-se a frota mínima de contêineres e que gere uma menor perda de transportes.

Para este cenário inicial utilizou-se um estoque inicial de contêineres (frota de contêineres) de tamanho grande o suficiente para que o sistema opere, garantindo que não ocorra perda de transportes por falta de contêineres. Este estoque inicial de contêineres (soma total dos estoques de contêineres cheios "in", estoques de contêineres "out" e estoques de vazios em todos os portos da rota considerada) foi determinado a partir de testes iniciais com o modelo.

Isso permitiu encontrar uma solução inicial com perda zero de contêineres, onde foi possível também avaliar qual é a capacidade de transporte dessa frota 
com a matriz de carga inserida. Com base nessa matriz de carga, foi então calibrada a quantidade diária de contêineres vazios que os clientes necessitam. As quantidades de contêineres nos estoques iniciais utilizados para a simulação deste cenário inicial são apresentadas na Tabela 5-3.

Tabela 5-3: Estoque inicial de contêineres do cenário inicial

\begin{tabular}{|l|r|}
\hline Estoque inicial de contêineres cheios "in" no PORTO 1 & 1.600 \\
\hline Estoque inicial de contêineres cheios "in" no PORTO 2 & 250 \\
\hline Estoque inicial de contêineres cheios "in" no PORTO 3 & 1.400 \\
\hline Estoque inicial de contêineres cheios "in" no PORTO 4 & 200 \\
\hline Estoque inicial de contêineres cheios "in" no PORTO 5 & 400 \\
\hline Estoque inicial de contêineres cheios "in" no PORTO 6 & 1.300 \\
\hline Estoque inicial de contêineres cheios "out" no PORTO 1 & 8.400 \\
\hline Estoque inicial de contêineres cheios "out" no PORTO 2 & 5.400 \\
\hline Estoque inicial de contêineres cheios "out" no PORTO 3 & 4.200 \\
\hline Estoque inicial de contêineres cheios "out" no PORTO 4 & 3.000 \\
\hline Estoque inicial de contêineres cheios "out" no PORTO 5 & 4.800 \\
\hline Estoque inicial de contêineres cheios "out" no PORTO 6 & 8.400 \\
\hline Estoque inicial de contêineres vazios no PORTO 1 & 9.000 \\
\hline Estoque inicial de contêineres vazios no PORTO 2 & 8.700 \\
\hline Estoque inicial de contêineres vazios no PORTO 3 & 4.200 \\
\hline Estoque inicial de contêineres vazios no PORTO 4 & 1.800 \\
\hline Estoque inicial de contêineres vazios no PORTO 5 & 3.600 \\
\hline Estoque inicial de contêineres vazios no PORTO 6 & 9.600 \\
\hline ESTOQUE INICIAL TOTAL DE CONTÊINERES & 76.250 \\
\hline
\end{tabular}

Com estes estoques iniciais da Tabela 5-3, simulou-se o cenário inicial e obtiveram-se as quantidades de contêineres cheios que desembarcam nos 6 portos da rota, além do total de contêineres gerado a partir das matrizes de cargas durante um ano. A Tabela 5-4 mostra as quantidades anuais e diárias de contêineres cheios necessários para atendimento da matriz de carga nos portos, bem como a quantidade de contêineres cheios que foram descarregados em cada um dos portos, mostrando assim o "imbalance" entre recebidos e despachados. 
Tabela 5-4: Quantidades diárias e anuais de contêineres necessários e desembarcados em cada porto

\begin{tabular}{|l|r|r|}
\cline { 2 - 3 } \multicolumn{1}{c|}{} & ANUAL & DIÁRIA \\
\hline Contêineres cheios necessários para o PORTO 1 & 114.848 & $\mathbf{3 1 5}$ \\
\hline Contêineres cheios necessários para o PORTO 2 & 57.216 & $\mathbf{1 5 7}$ \\
\hline Contêineres cheios necessários para o PORTO 3 & 46.560 & $\mathbf{1 2 8}$ \\
\hline Contêineres cheios necessários para o PORTO 4 & 14.322 & $\mathbf{3 9}$ \\
\hline Contêineres cheios necessários para o PORTO 5 & 71.910 & $\mathbf{1 9 7}$ \\
\hline Contêineres cheios necessários para o PORTO 6 & 170.892 & $\mathbf{4 6 8}$ \\
\hline Contêineres cheios desembarcados no PORTO 1 & 149.916 & $\mathbf{4 1 1}$ \\
\hline Contêineres cheios desembarcados no PORTO 2 & 20.268 & $\mathbf{5 6}$ \\
\hline Contêineres cheios desembarcados no PORTO 3 & 122.772 & $\mathbf{3 3 6}$ \\
\hline Contêineres cheios desembarcados no PORTO 4 & 10.695 & $\mathbf{2 9}$ \\
\hline Contêineres cheios desembarcados no PORTO 5 & 37.722 & $\mathbf{1 0 3}$ \\
\hline Contêineres cheios desembarcados no PORTO 6 & 126.734 & $\mathbf{3 4 7}$ \\
\hline
\end{tabular}

Também nessa simulação foi obtido o tempo de ciclo médio dos navios que, dividido pelo tamanho da frota (4 navios), forneceu o intervalo médio com os quais os navios devem ser inseridos no início do processamento da simulação. Cabe ressaltar que neste início da simulação, cada navio está vazio e inicia o ciclo pelo primeiro porto da sequência. Sendo o ciclo médio de 365 horas e a frota composta por 4 navios, o intervalo é igual a 91 horas.

Os resultados obtidos com a simulação deste cenário inicial estão apresentados na Tabela 5-5: Resultados obtidos na simulação do cenário inicial. 
Tabela 5-5: Resultados obtidos na simulação do cenário inicial

\begin{tabular}{|c|c|c|c|c|c|c|}
\hline & PORTO & $\begin{array}{l}\text { PORTO } \\
2\end{array}$ & PORTO & $\begin{array}{l}\text { PORTO } \\
4\end{array}$ & $\begin{array}{l}\text { PORTO } \\
5\end{array}$ & $\begin{array}{l}\text { PORTO } \\
6\end{array}$ \\
\hline $\begin{array}{l}\text { 1. Quantidade de contêineres } \\
\text { descarregada dos navios }\end{array}$ & 149.916 & 20.268 & 122.772 & 10.695 & 37.722 & 126.734 \\
\hline $\begin{array}{l}\text { 2. Quantidade de contêineres } \\
\text { cheios enviados para terra }\end{array}$ & 151.516 & 20.518 & 124.172 & 10.895 & 38.122 & 128.034 \\
\hline $\begin{array}{l}\text { 3. Quantidade de contêineres } \\
\text { vazios enviados aos portos }\end{array}$ & 145.068 & 19.638 & 118.960 & 10.435 & 36.510 & 122.638 \\
\hline $\begin{array}{l}\text { 4. Quantidade de contêineres } \\
\text { vazios reposicionados para o } \\
\text { porto }\end{array}$ & 0 & 32.954 & 0 & 3.454 & 32.430 & 42.016 \\
\hline $\begin{array}{l}\text { 5. Estoque final de contêineres } \\
\text { vazios nos portos }\end{array}$ & 2.176 & 5.528 & 1.748 & 1.730 & 0 & 0 \\
\hline $\begin{array}{l}\text { 6. Quantidade de contêineres } \\
\text { vazios reposicionados para } \\
\text { outros portos }\end{array}$ & 37.062 & 0 & 75.999 & 0 & 0 & 0 \\
\hline $\begin{array}{l}\text { 7. Quantidade gerada de } \\
\text { contêineres vazios dos portos }\end{array}$ & 114.830 & 55.764 & 45.413 & 13.959 & 73.717 & 176.939 \\
\hline $\begin{array}{l}\text { 8. Quantidade de contêineres } \\
\text { vazios retirados nos portos }\end{array}$ & 114.830 & 55.764 & 45.413 & 13.959 & 72.540 & 174.254 \\
\hline $\begin{array}{l}\text { 9. Quantidade de contêineres } \\
\text { cheios entregues nos portos }\end{array}$ & 110.608 & 53.648 & 43.634 & 13.451 & 69.883 & 166.982 \\
\hline $\begin{array}{l}\text { 10. Estoque final de } \\
\text { contêineres cheios para } \\
\text { embarque nos portos }\end{array}$ & 4.160 & 1.832 & 1.274 & 2.129 & 2.773 & 4.490 \\
\hline $\begin{array}{l}\text { 11. Perda de transporte por } \\
\text { porto }\end{array}$ & 0 & 0 & 0 & 0 & 0 & 0 \\
\hline $\begin{array}{l}\text { 12. Quantidade de contêineres } \\
\text { gerada no porto }\end{array}$ & 114.848 & 16 & 560 & 22 & 910 & 170.892 \\
\hline $\begin{array}{l}\text { 13. Quantidade de contêineres } \\
\text { embarcada no porto }\end{array}$ & 114.848 & 57.216 & 46.560 & 14.322 & 71.910 & 170.892 \\
\hline
\end{tabular}

Observa-se pelos resultados obtidos que o reposicionamento de contêineres vazios ocorreu dos portos 1 e 3 (ofertantes) para os portos 2, 4, 5 e 6 (demandantes), de acordo com os dados apresentados na seção 5.1. Além disso, o estoque inicial (frota) utilizado foi, realmente, suficiente para que não houvesse perda de demanda nos portos.

Também pôde ser constatado com a simulação deste cenário inicial que o navio 1 realizou 24 ciclos completos, enquanto que os outros três navios realizaram 23 ciclos (devido ao intervalo entre os posicionamentos dos navios no primeiro porto da sequência, que fez com que o navio 1 realizasse uma viagem completa a mais). O tempo médio de ciclo foi de 364,5 horas. 
É importante também a visualização do comportamento dos estoques de contêineres cheios ("in" e "out") e vazios ao longo dos 365 dias simulados, apresentados em forma de gráficos.

Tais gráficos são obtidos diretamente no modelo de simulação e ajudam a tomar algumas conclusões acerca do funcionamento do sistema.

O primeiro gráfico, apresentado na Figura 5-5, apresenta o comportamento do estoque de contêineres cheios "in", os que são desembarcados nos portos para serem enviados aos clientes em terra. Observe que ainda nos primeiros dias de operação o estoque entra em um regime permanente em todos os portos, pois os contêineres chegam aos terminais e são despachados em sua totalidade para os clientes em terra, zerando o estoque de contêineres cheios "in", que volta a ser abastecido quando o próximo navio operar.

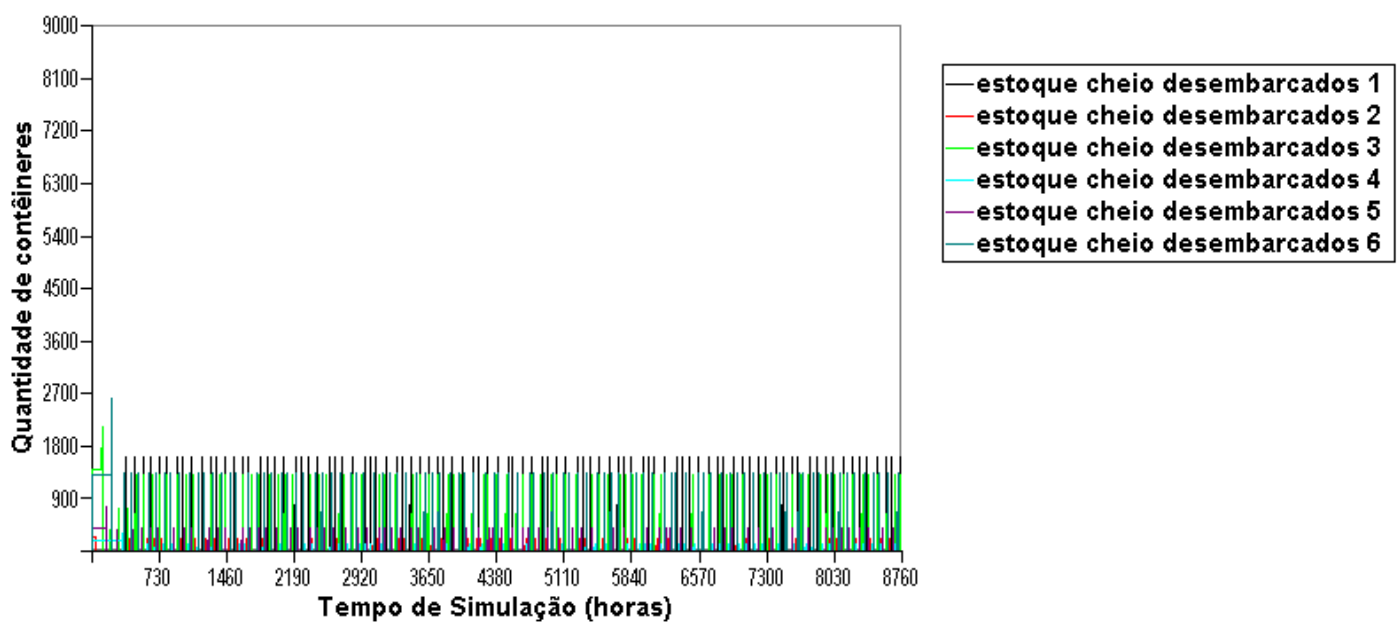

Figura 5-5: Gráfico do comportamento do estoque de contêineres cheios "in" nos portos - cenário inicial

A Figura 5-6 mostra o gráfico de comportamento do estoque de contêineres cheios "out", os que chegam carregados pelos clientes a fim de serem embarcados e transportados para outros portos. Caso esse estoque de contêineres cheios "out" chegue a zero, haverá perda de transporte, pois significa que o porto não conseguiu enviar contêineres vazios a tempo de serem carregados por seus clientes ou ainda que os clientes não enviaram os contêineres em tempo hábil. Observa-se que o comportamento do estoque se 
mantém em regime estacionário depois de um período de tempo e, em nenhum dos portos, se aproxima de zero, comprovando que não há perda de transporte.

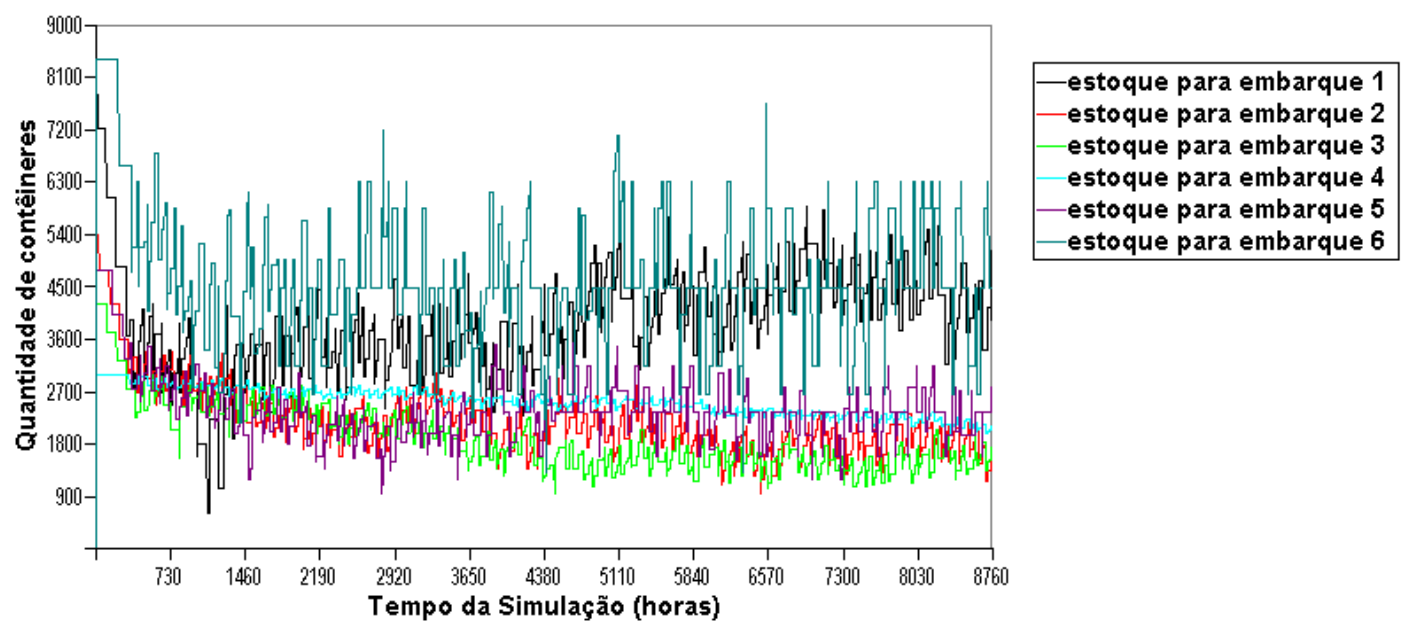

Figura 5-6: Gráfico do comportamento do estoque de contêineres cheios "out" nos portos - cenário inicial

O terceiro gráfico de estoque obtido com o modelo de simulação é o de estoque de contêineres vazios, apresentado na Figura 5-7. Observe que os estoques nos seis portos também entram em um regime estacionário antes do segundo mês de operação (1460 horas) para todos os portos, mostrando que 0 reposicionamento de contêineres dos portos ofertantes para os demandantes é feito de maneira eficiente, uma vez que a tendência deveria ser de queda de estoque nos portos 2, 4, 5 e 6 (demandantes) e crescente para os portos 1 e 3 , ofertantes. 


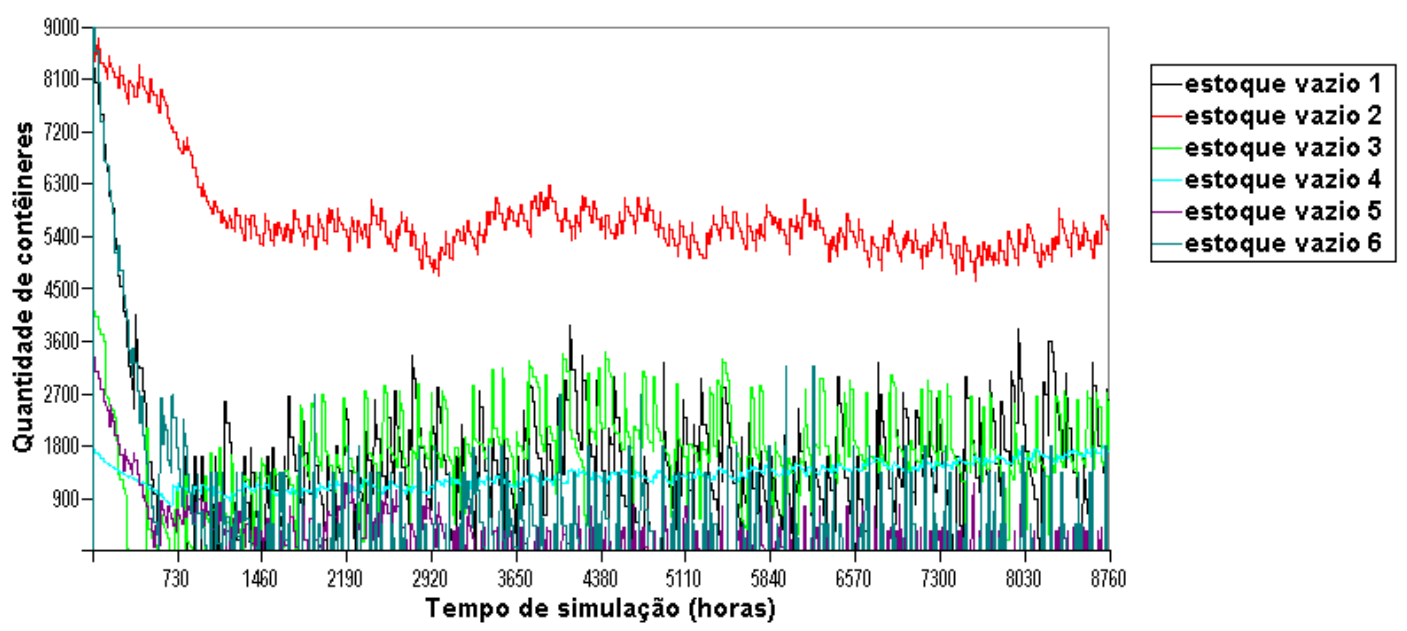

Figura 5-7: Gráfico do comportamento do estoque de contêineres vazios nos portos cenário inicial

Deve ser observado, então, que, para que o sistema funcione atendendo às matrizes de cargas dos navios integralmente, o estoque de contêineres cheios "out" não pode chegar a zero, o que não impede que o estoque de vazios chegue a este patamar, desde que haja tempo hábil para a devolução destes contêineres depois de cheios.

Após a simulação desse cenário inicial, o modelo pode ser considerado validado para o estoque inicial utilizado (frota de contêineres), uma vez que as quantidades de contêineres movimentados e tempos de ciclos são semelhantes aos esperados a partir dos dados de entrada. Deve-se, então, partir em busca da frota de contêineres que minimize a função objetivo.

5.4. BUSCA DA MELHOR SOLUÇÃO PARA O PROBLEMA: DIMENSIONAMENTO DA FROTA DE CONTÊINERES MINIMIZANDO PERDAS DE TRANSPORTE ATRAVÉS DE MULTIPLICAÇÃO DO TERMO NA FUNÇÃO OBJETIVO

Em um problema de otimização clássico, busca-se a minimização de uma função objetivo através de variáveis de decisão adequadas. Para o problema apresentado, deseja-se dimensionar a frota de contêineres (estoques iniciais) 
de modo a obter a menor perda de transporte possível. Para minimizar a perda de transportes e obter um estoque inicial mínimo, estabelece-se como função objetivo a soma entre a perda de transporte e a quantidade de contêineres em estoque.

É possível ainda priorizar a minimização do estoque ou da perda. Para isso, multiplica-se um dos fatores que compõem a função objetivo por um valor muito alto, de modo a buscar que a minimização desta função seja obtida através da minimização do fator multiplicado.

Para a busca da melhor solução e respostas do sistema, foi utilizada a ferramenta OptQuest do ARENA®. O processo de busca considerou os estoques iniciais nos portos (cheios "in", cheios "out" e vazios) como variáveis de decisão.

\subsubsection{A ferramenta de busca da melhor solução OptQuest}

O OptQuest é um mecanismo de busca da melhor solução que se baseia em técnicas de Busca Dispersa (scatter search) associadas ao procedimento de Busca Tabu (tabu search) com a finalidade de obter soluções para problemas definidos em ferramentas complexas (Laguna, 1997). Trata-se de uma ferramenta conhecida como "caixa preta", na qual se trata diretamente da função objetivo sem que se tome conhecimento da estrutura por trás desta, da formulação do problema.

Em outras palavras, o OptQuest busca as variáveis de decisão que se aproximem da solução ótima do problema, através da avaliação das respostas obtidas para a função objetivo, baseando-se em heurísticas. Uma heurística (ou uma meta-heurística) não garante que a solução encontrada é exatamente a solução ótima de um problema, mas pode facilitar a resolução do mesmo fornecendo uma resposta muito próxima desta solução ótima desejada.

De acordo com Laguna (1997), a Busca Dispersa é uma meta-heurística para busca da melhor solução aplicada em problemas de variáveis discretas ou contínuas, que considera cinco etapas: 
1. Geração diversificada: para criar um conjunto de soluções que servirão como base da busca,

2. Melhoria de soluções: transformar as variáveis do conjunto de soluções buscando aumentar a qualidade das respostas;

3. Atualização do conjunto referência: manutenção de conjuntos solução utilizadas como referência para combinações lineares;

4. Geração de subconjuntos: gera subconjuntos com respostas que podem ser utilizadas para a obtenção da resposta final;

5. Combinação linear de soluções: utiliza as respostas obtidas na geração de subconjuntos para criar novas soluções e testá-las.

A Busca Dispersa utiliza escolhas estratégicas e memória computacional para transformar combinações de soluções já obtidas em novas soluções.

O OptQuest utiliza a Busca Dispersa e trabalha as soluções testadas através de intervalos, com valores limites mínimos e máximos já especificados. A solução inicial gerada pela ferramenta pode incluir valores sugeridos e inclui o ponto médio entre os limites mínimos e máximos considerados. A cada solução gerada, é testada a resposta e, então, memorizada a que melhor se aproximar do ponto ótimo. Dessa forma, quanto maior a quantidade de experimentos, melhor a aproximação da solução ótima obtida.

Nos experimentos realizados com o OptQuest neste trabalho, utilizou-se como limite mínimo o valor zero e como limite máximo a quantidade de contêineres a ser movimentada anualmente em cada porto, pois dessa maneira, deve estar garantido que a resposta esteja no intervalo determinado.

5.4.2. Dimensionamento da frota de contêineres: minimização dos estoques iniciais nos portos

Inicialmente, foi realizado um experimento de 1.000 simulações, com 5 replicações cada uma, para determinar o estoque inicial de contêineres que minimizava a função objetivo sem ponderar nenhum dos fatores que a compunham (soma entre perda de transportes com o estoque inicial). $O$ 
computador utilizado é equipado com um processador Intel $\circledast \mathrm{i}$, com $8 \mathrm{MB}$ de memória RAM e a duração total do experimento (1.000 simulações) foi de 550 minutos.

Depois dessa simulação, os resultados obtidos com o OptQuest sugeriram que a função objetivo mínima foi obtida no experimento número 882. Foi obtida uma função objetivo de 66.279, representando um estoque total de contêineres de 64.972 e perda de transporte de 1.317 contêineres dos clientes. O estoque inicial de contêineres é apresentado de forma detalhada na Tabela 5-6, na qual é possível comparar também com os estoques utilizados no cenário inicial apresentado na Seção 5.3 .

Tabela 5-6: Estoque inicial de contêineres do cenário melhorado (busca da melhor solução) com perdas

\begin{tabular}{|l|r|r|}
\multicolumn{1}{l|}{} & \multicolumn{1}{l}{$\begin{array}{l}\text { simulação } \\
\text { inicial }\end{array}$} & $\begin{array}{l}\text { lomponentes da } \\
\text { função objetivo) }\end{array}$ \\
\hline Estoque inicial de contêineres cheios "in" - Porto 1 & 1.600 & 1.470 \\
\hline Estoque inicial de contêineres cheios "in" - Porto 2 & 250 & 209 \\
\hline Estoque inicial de contêineres cheios "in" - Porto 3 & 1.400 & 1.344 \\
\hline Estoque inicial de contêineres cheios "in" - Porto 4 & 200 & 200 \\
\hline Estoque inicial de contêineres cheios "in" - Porto 5 & 400 & 371 \\
\hline Estoque inicial de contêineres cheios "in" - Porto 6 & 1.300 & 1.184 \\
\hline Estoque inicial de contêineres cheios "out" - Porto 1 & 8.400 & 8.012 \\
\hline Estoque inicial de contêineres cheios "out" - Porto 2 & 5.400 & 4.441 \\
\hline Estoque inicial de contêineres cheios "out" - Porto 3 & 4.200 & 4.132 \\
\hline Estoque inicial de contêineres cheios "out" - Porto 4 & 3.000 & 2.590 \\
\hline Estoque inicial de contêineres cheios "out" - Porto 5 & 4.800 & 3.146 \\
\hline Estoque inicial de contêineres cheios "out" - Porto 6 & 8.400 & 8.108 \\
\hline Estoque inicial de contêineres vazios - Porto 1 & 9.000 & 7.988 \\
\hline Estoque inicial de contêineres vazios - Porto 2 & 8.700 & 5.241 \\
\hline Estoque inicial de contêineres vazios - Porto 3 & 4.200 & 3.779 \\
\hline Estoque inicial de contêineres vazios - Porto 4 & 1.800 & 10 \\
\hline Estoque inicial de contêineres vazios - Porto 5 & 3.600 & 3.147 \\
\hline Estoque inicial de contêineres vazios - Porto 6 & 9.600 & 9.600 \\
\hline Total & 76.250 & 64.972 \\
\hline
\end{tabular}


Nota-se que a quantidade inicial em estoque adotada cai de 76.250 (seção 5.3) unidades para 64.972 contêineres, uma diferença de 11.278 recipientes. No entanto, é preciso lembrar que houve a perda de 1.314 contêineres.

$\mathrm{Na}$ simulação do modelo com os estoques iniciais obtidos na minimização da função objetivo (com perda) foram obtidos os resultados apresentados na Tabela 5-7.

Tabela 5-7: Resultados obtidos na simulação do cenário melhorado com perda de transporte

\begin{tabular}{|c|c|c|c|c|c|c|}
\hline & \begin{tabular}{c|} 
PORTO \\
1
\end{tabular} & $\begin{array}{c}\text { PORTO } \\
2 \\
\end{array}$ & $\begin{array}{c}\text { PORTO } \\
3 \\
\end{array}$ & $\begin{array}{c}\text { PORTO } \\
4 \\
\end{array}$ & $\begin{array}{c}\text { PORTO } \\
5 \\
\end{array}$ & $\begin{array}{c}\text { PORTO } \\
6 \\
\end{array}$ \\
\hline $\begin{array}{l}\text { 1. Quantidade de contêineres } \\
\text { descarregada dos navios }\end{array}$ & 147.792 & 20.202 & 120.692 & 10.582 & 37.993 & 126.016 \\
\hline $\begin{array}{l}\text { 2. Quantidade de contêineres } \\
\text { cheios enviados para terra }\end{array}$ & 149.262 & 20.411 & 122.036 & 10.782 & 38.364 & 127.200 \\
\hline $\begin{array}{l}\text { 3. Quantidade de contêineres } \\
\text { vazios enviados aos portos }\end{array}$ & 142.814 & 19.311 & 116.824 & 10.322 & 36.752 & 123.153 \\
\hline $\begin{array}{l}\text { 4. Quantidade de contêineres } \\
\text { vazios reposicionados para o } \\
\text { porto }\end{array}$ & 0 & 31.219 & 0 & 3.411 & 2.372 & 41.472 \\
\hline $\begin{array}{l}\text { 5. Estoque final de contêineres } \\
\text { vazios nos portos }\end{array}$ & 1.346 & 385 & 1.177 & 0 & 0 & 1.349 \\
\hline $\begin{array}{l}\text { 6. Quantidade de contêineres } \\
\text { vazios reposicionados para } \\
\text { outros portos }\end{array}$ & 34.704 & 0 & 74.360 & 0 & 0 & 0 \\
\hline $\begin{array}{l}\text { 7. Quantidade gerada de } \\
\text { contêineres vazios dos portos }\end{array}$ & 114.752 & 56.366 & 45.066 & 14.257 & 75.108 & 173.538 \\
\hline $\begin{array}{l}\text { 8. Quantidade de contêineres } \\
\text { vazios retirados nos portos }\end{array}$ & 114.752 & 55.386 & 45.962 & 13.733 & 72.271 & 172.876 \\
\hline $\begin{array}{l}\text { 9. Quantidade de contêineres } \\
\text { cheios entregues nos portos }\end{array}$ & 110.408 & 53.736 & 43.161 & 13.117 & 69.211 & 165.604 \\
\hline $\begin{array}{l}\text { 10. Estoque final de } \\
\text { contêineres cheios para } \\
\text { embarque nos portos }\end{array}$ & 5.246 & 961 & 1.218 & 1.385 & 1.164 & 3.166 \\
\hline $\begin{array}{l}\text { 11. Perda de transporte por } \\
\text { porto }\end{array}$ & 490 & 0 & 0 & 0 & 482 & 346 \\
\hline $\begin{array}{l}\text { 12. Quantidade de contêineres } \\
\text { gerada no porto }\end{array}$ & 113.663 & 57.216 & 46.075 & 14.322 & 72.675 & 170.892 \\
\hline $\begin{array}{l}\text { 13. Quantidade de contêineres } \\
\text { embarcada no porto }\end{array}$ & 113.173 & 57.216 & 46.075 & 14.322 & 72.193 & 170.546 \\
\hline
\end{tabular}


Observe nos resultados da Tabela 5-7 que as perdas de transporte ocorreram nos portos 1, 5 e 6, mesmo havendo o reposicionamento de contêineres vazios entre os portos.

O ideal, entretanto, seria buscar a menor frota de contêineres com perda de transporte zero. Para tanto, na função objetivo foi incorporado um fator multiplicador para as perdas de transporte. Em novos cenários multiplicou-se a perda de transporte, na função objetivo, por 100, 1.000, 10.000, e 1.000.000. Dessa forma, ao buscar a minimização da função objetivo, o OptQuest deve forçar a busca por uma perda zero de transportes e minimizar os estoques iniciais para determinar aquele estoque que atende às necessidades da rota. Os valores obtidos com estes testes estão apresentados na Tabela 5-8.

Tabela 5-8: Estoques de contêineres obtidos em experimentos com fator multiplicador da perda na função objetivo

\begin{tabular}{|c|c|c|c|c|c|}
\hline Fator multiplicador da perda & 1 & 100 & 1.000 & 10.000 & 1.000 .000 \\
\hline Estoque inicial de vazios porto 1 & 7.988 & 8.921 & 1.594 & 1.594 & 1.594 \\
\hline Estoque inicial de vazios porto 2 & 5.241 & 977 & 250 & 250 & 250 \\
\hline Estoque inicial de vazios porto 3 & 3.779 & 4.162 & 1.336 & 1.336 & 1.336 \\
\hline Estoque inicial de vazios porto 4 & 10 & 1.786 & 200 & 200 & 200 \\
\hline Estoque inicial de vazios porto 5 & 3.147 & 3.559 & 395 & 395 & 395 \\
\hline Estoque inicial de vazios porto 6 & 9.600 & 9.525 & 1.298 & 1.298 & 1.298 \\
\hline Estoque inicial de cheios out porto 1 & 8.012 & 8.303 & 8.391 & 8.391 & 8.391 \\
\hline Estoque inicial de cheios out porto 2 & 4.441 & 7.057 & 7.099 & 7.099 & 7.099 \\
\hline Estoque inicial de cheios out porto 3 & 4.132 & 4.147 & 4.200 & 4.200 & 4.200 \\
\hline Estoque inicial de cheios out porto 4 & 2.590 & 2.918 & 2.967 & 2.967 & 2.967 \\
\hline Estoque inicial de cheios out porto 5 & 3.146 & 4.787 & 4.777 & 4.777 & 4.777 \\
\hline Estoque inicial de cheios out porto 6 & 8.108 & 8.232 & 8.395 & 8.395 & 8.395 \\
\hline Estoque inicial de cheios in porto 1 & 1.470 & 1.580 & 8.998 & 8.998 & 8.998 \\
\hline Estoque inicial de cheios in porto 2 & 209 & 247 & 1.002 & 1.002 & 1.002 \\
\hline Estoque inicial de cheios in porto 3 & 1.344 & 1.379 & 4.084 & 4.084 & 4.084 \\
\hline Estoque inicial de cheios in porto 4 & 200 & 199 & 1.772 & 1.772 & 1.772 \\
\hline Estoque inicial de cheios in porto 5 & 371 & 396 & 3.598 & 3.598 & 3.598 \\
\hline Estoque inicial de cheios in porto 6 & 1.184 & 1.279 & 9.580 & 9.580 & 9.580 \\
\hline Estoque total inicial & 64.972 & 69.454 & 69.936 & 69.936 & 69.936 \\
\hline Perda total & 1.317 & 22 & 4 & - & - \\
\hline Função objetivo & 66.279 & 69.674 & 69.936 & 69.936 & 69.936 \\
\hline
\end{tabular}

Ao obter perda de transporte igual zero, houve um aumento da frota de contêineres no sistema. No entanto, essa frota ainda é menor que a frota inicial 
utilizada. Quando se multiplicou o fator da perda em 10 vezes, o estoque inicial de contêineres aumentou de 64.972 para 69.454 , quantidade menor que os 76.250 contêineres utilizados na simulação do cenário inicial da seção 5.3,mas ainda houve uma perda de transporte, de 22 contêineres. Ao minimizar a função objetivo com um fator multiplicador de 100 vezes na perda de transportes, obteve-se um estoque de 69.936 contêineres no sistema, sem perda de transporte.

Esse estoque inicial se repetiu nos experimentos que consideraram o fator multiplicador da perda de transporte igual a $1.000,10.000$ e 1.000.000. A Tabela 5-9 destaca o estoque inicial de contêineres que proporcionou 0 estoque mínimo sem perda de transportes.

Tabela 5-9: Estoque inicial de contêineres do cenário otimizado

\begin{tabular}{|l|r|}
\cline { 2 - 2 } \multicolumn{1}{c|}{} & Estoque inicial otimizado \\
\hline Estoque inicial de contêineres cheios "in" - Porto 1 & 1.594 \\
\hline Estoque inicial de contêineres cheios "in" - Porto 2 & 250 \\
\hline Estoque inicial de contêineres cheios "in" - Porto 3 & 1.336 \\
\hline Estoque inicial de contêineres cheios "in" - Porto 4 & 200 \\
\hline Estoque inicial de contêineres cheios "in" - Porto 5 & 395 \\
\hline Estoque inicial de contêineres cheios "out" - Porto 1 & 1.298 \\
\hline Estoque inicial de contêineres cheios "out" - Porto 2 & 8.391 \\
\hline Estoque inicial de contêineres cheios "out" - Porto 3 & 7.099 \\
\hline Estoque inicial de contêineres cheios "out" - Porto 4 & 4.200 \\
\hline Estoque inicial de contêineres cheios "out" - Porto 5 & 2.967 \\
\hline Estoque inicial de contêineres cheios "out" - Porto 6 & 4.777 \\
\hline Estoque inicial de contêineres vazios - Porto 1 & 8.395 \\
\hline Estoque inicial de contêineres vazios - Porto 2 & 8.998 \\
\hline Estoque inicial de contêineres vazios - Porto 3 & 1.002 \\
\hline Estoque inicial de contêineres vazios - Porto 4 & 4.084 \\
\hline Estoque inicial de contêineres vazios - Porto 5 & 1.772 \\
\hline Estoque inicial de contêineres vazios - Porto 6 & 3.598 \\
\hline Total & 9.580 \\
\hline
\end{tabular}

Os resultados obtidos na simulação do cenário com o estoque inicial otimizado (fator de ponderação maior ou igual a 100) são apresentados na Tabela 5-10. 
Tabela 5-10: Resultados obtidos na simulação do cenário otimizado

\begin{tabular}{|c|c|c|c|c|c|c|}
\hline & $\begin{array}{l}\text { PORTO } \\
1\end{array}$ & $\begin{array}{l}\text { PORTO } \\
2\end{array}$ & $\begin{array}{l}\text { PORTO } \\
3\end{array}$ & $\begin{array}{l}\text { PORTO } \\
4\end{array}$ & $\begin{array}{l}\text { PORTO } \\
5\end{array}$ & \begin{tabular}{|l|} 
PORTO \\
6 \\
\end{tabular} \\
\hline $\begin{array}{l}\text { 1. Quantidade de contêineres } \\
\text { descarregada dos navios }\end{array}$ & 148.304 & 20.268 & 121.469 & 10.695 & 37.722 & 126.734 \\
\hline $\begin{array}{l}\text { 2. Quantidade de contêineres } \\
\text { cheios enviados para terra }\end{array}$ & 149.898 & 20.518 & 122.805 & 10.895 & 38.117 & 128.032 \\
\hline $\begin{array}{l}\text { 3. Quantidade de contêineres } \\
\text { vazios enviados aos portos }\end{array}$ & 143.450 & 19.638 & 117.593 & 10.435 & 36.505 & 122.636 \\
\hline $\begin{array}{l}\text { 4. Quantidade de contêineres } \\
\text { vazios reposicionados para o } \\
\text { porto }\end{array}$ & 0 & 32.543 & 0 & 3.409 & 32.009 & 41.469 \\
\hline $\begin{array}{l}\text { 5. Estoque final de contêineres } \\
\text { vazios nos portos }\end{array}$ & 1.996 & 0 & 1.381 & 1.521 & 765 & 0 \\
\hline $\begin{array}{l}\text { 6. Quantidade de contêineres } \\
\text { vazios reposicionados para } \\
\text { outros portos }\end{array}$ & 36.176 & 0 & 74.206 & 0 & 0 & 0 \\
\hline $\begin{array}{l}\text { 7. Quantidade gerada de } \\
\text { contêineres vazios dos portos }\end{array}$ & 114.276 & 56.362 & 46.090 & 14.095 & 71.347 & 174.195 \\
\hline $\begin{array}{l}\text { 8. Quantidade de contêineres } \\
\text { vazios retirados nos portos }\end{array}$ & 114.276 & 53.183 & 46.090 & 14.095 & 71.347 & 173.685 \\
\hline $\begin{array}{l}\text { 9. Quantidade de contêineres } \\
\text { cheios entregues nos portos }\end{array}$ & 111.009 & 50.378 & 44.383 & .506 & 68.575 & 166.413 \\
\hline $\begin{array}{l}\text { 10. Estoque final de } \\
\text { contêineres cheios para } \\
\text { embarque nos portos }\end{array}$ & 5.736 & 262 & 2.508 & 2.151 & 1.442 & 3.916 \\
\hline $\begin{array}{l}\text { 11. Perda de transporte por } \\
\text { porto }\end{array}$ & 0 & 0 & 0 & 0 & 0 & 0 \\
\hline $\begin{array}{l}\text { 12. Quantidade de contêineres } \\
\text { gerada no porto }\end{array}$ & 113.664 & .216 & 75 & 22 & 910 & 179.892 \\
\hline $\begin{array}{l}\text { 13. Quantidade de contêineres } \\
\text { embarcada no porto }\end{array}$ & 113.664 & 57.216 & 46.075 & 14.322 & 71.910 & 179.892 \\
\hline
\end{tabular}

O modelo forneceu também os gráficos de comportamento dos estoques vazios, cheios "in" e cheios "out". A Figura 5-8 apresenta o gráfico dos estoques de contêineres "in" nos portos que compõem a rota. 


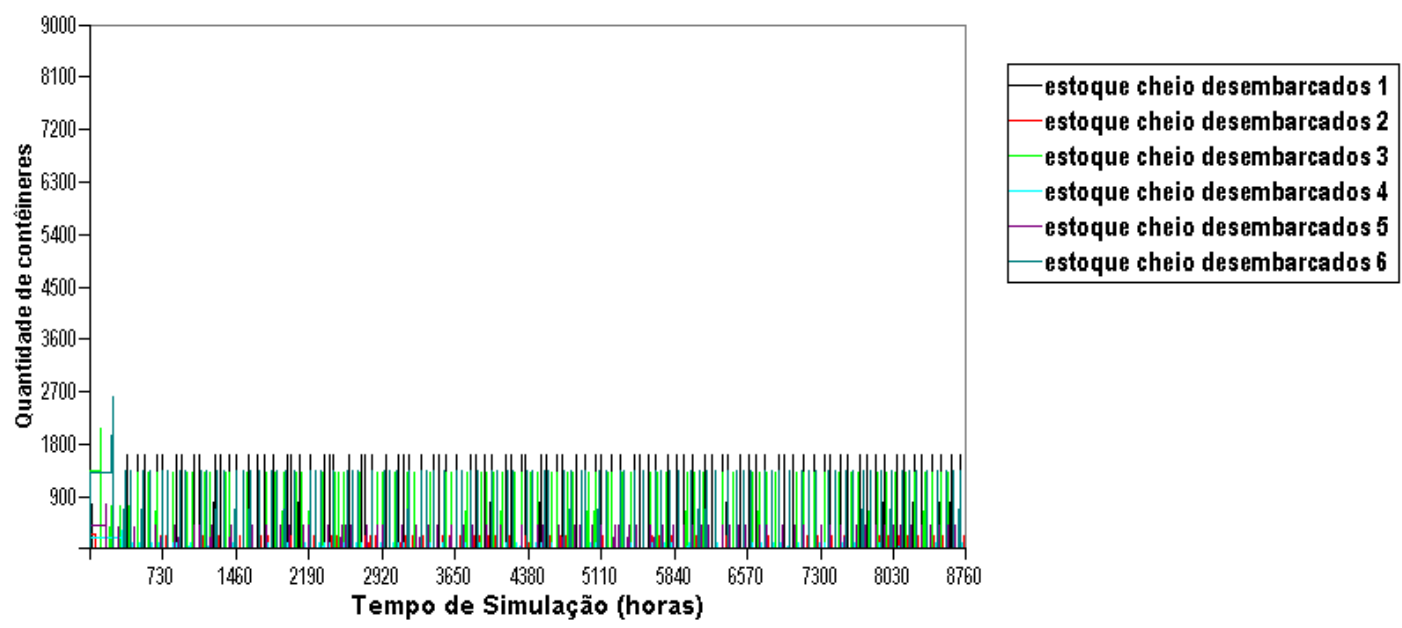

Figura 5-8: Gráfico do comportamento do estoque de contêineres cheios "in" nos portos - cenário otimizado

Observe que ainda nos primeiros dias de operação o estoque entra em um regime permanente em todos os portos, pois os contêineres chegam aos terminais e são despachados em sua totalidade para os clientes em terra, zerando o estoque de contêineres cheios "in", que volta a ser abastecido quando o próximo navio operar.

A Figura 5-9 apresenta o gráfico de comportamento do estoque de contêineres cheios "out", os que estão carregados nos portos, aguardando para ser embarcados nos navios. É possível observar que estes estoques não se aproximam de zero durante o período de um ano simulado, o que significa não haver perdas de transporte. 

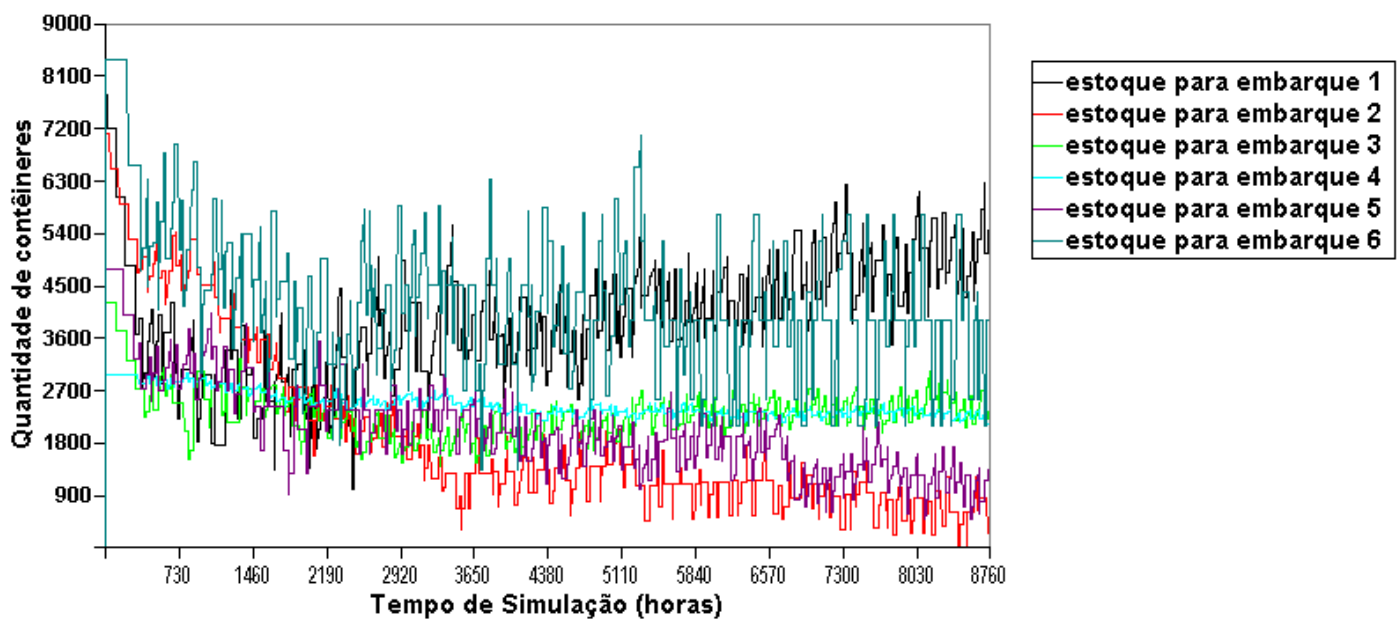

Figura 5-9: Gráfico do comportamento do estoque de contêineres cheios "out" nos portos - cenário otimizado

Por fim, a Figura 5-10 apresenta o comportamento de contêineres vazios nos portos.
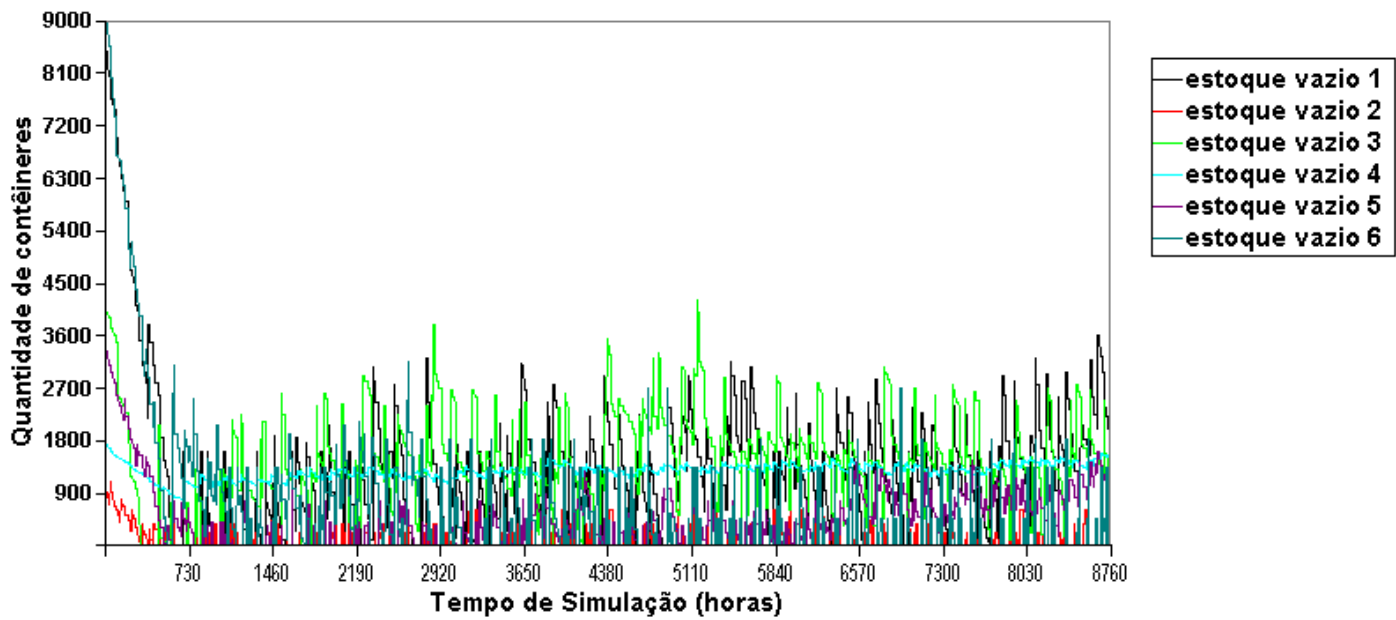

Figura 5-10: Gráfico do comportamento do estoque de contêineres vazios nos portos cenário otimizado

O estoque de contêineres vazios mostra que existe estabilidade e que o sistema mantém um regime permanente, a partir da primeira viagem dos navios. Este fato mostra que o planejamento possibilita a operação em todos os terminais com riscos irrisórios de eventual perda de transporte. 
Para uma melhor análise dos resultados obtidos, a Figura 5-11 traz, lado a lado, os gráficos obtidos para o cenário inicial apresentado na seção $5.3 \mathrm{com}$ os gráficos obtidos para este cenário otimizado.

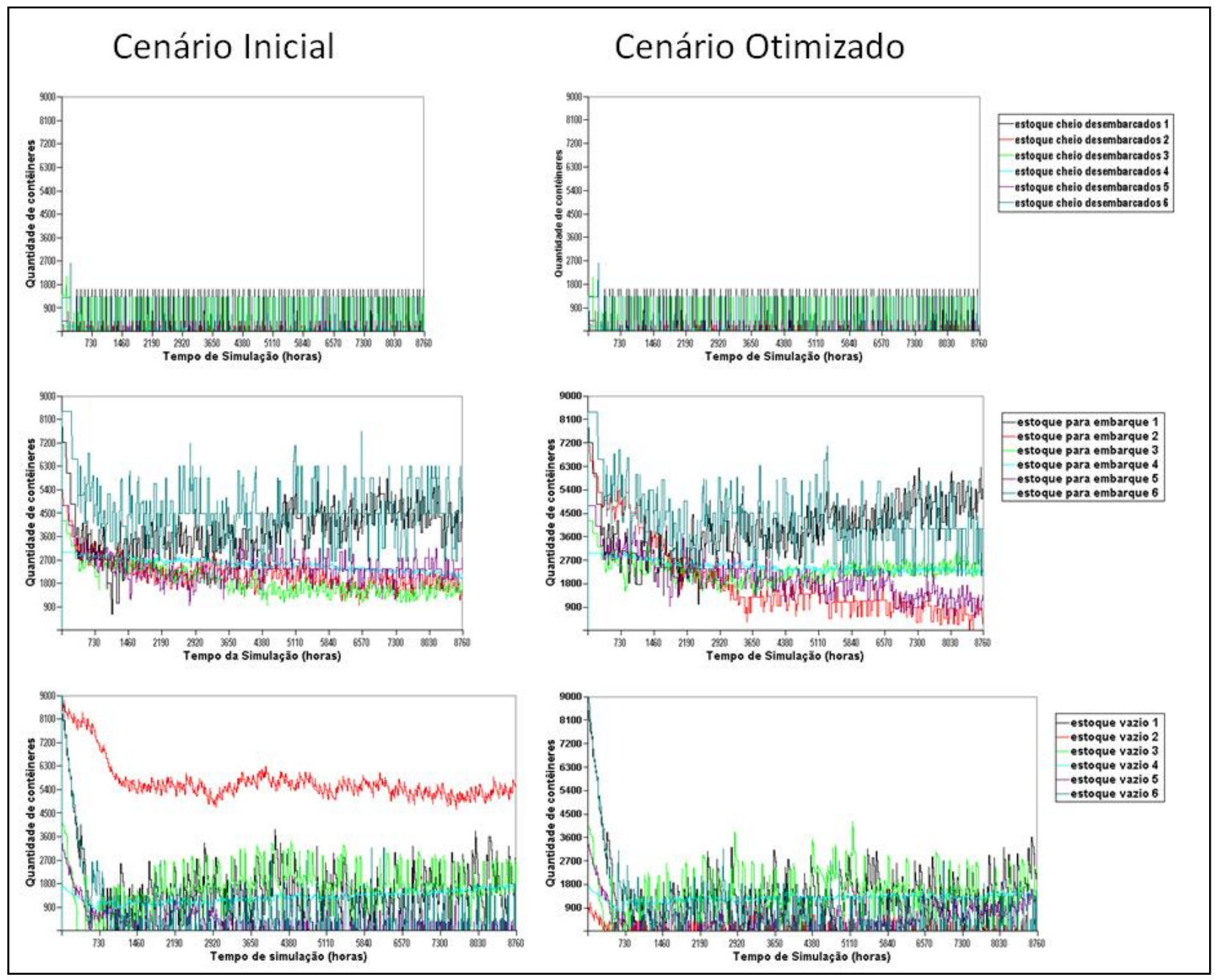

Figura 5-11: Comparação entre gráficos de comportamento de estoque dos cenários inicial e otimizado

Da figura 5.1 pode-se mostrar que o estoque total no sistema é menor no cenário otimizado do que no cenário inicial, com destaque para o porto 2 que tinha um estoque de vazio desnecessário ao longo do tempo.

A partir deste cenário com o estoque otimizado e a perda de transporte igual a zero serão realizadas algumas análises de sensibilidade com a variação de 
alguns parâmetros do sistema. Por este motivo, a partir de agora tal cenário será chamado de cenário base.

\subsection{ANÁLISES DE SENSIBILIDADE}

Com o intuito de verificar a robustez do modelo de simulação construído e enriquecer o conjunto de resultados obtidos, algumas análises de sensibilidade são propostas, de modo a verificar o comportamento do sistema em função de algumas variáveis.

Determinados os dados de entrada para o cenário base, o que inclui o estoque inicial de contêineres nos portos, foram realizadas modificações neste cenário, para que pudesse ser analisado o comportamento do sistema frente a algumas alterações nas características representadas por dados de entrada no modelo. As análises consideradas são:

- Variação da demanda através do aumento da velocidade dos navios da frota;

- Alterações nos tempos de retenções dos contêineres (cheios e vazios) em terra;

- Redução da capacidade de reposicionamento dos navios;

\subsubsection{Variação da velocidade dos navios}

A primeira análise de sensibilidade proposta considera a variação da velocidade dos navios que operam na rota. O aumento da velocidade das embarcações faz com que as viagens entre os portos sejam mais rápidas e, consequentemente, mais ciclos sejam realizados. Com mais visitas aos portos, maior a demanda a ser atendida. Da mesma forma, diminuindo-se a velocidade, menor será a demanda solicitada pelos navios e suas matrizes de carga. 
Resumindo, pode-se dizer que a variação da demanda a ser atendida é diretamente proporcional à velocidade média dos navios.

Para verificar a sensibilidade do sistema à variação da velocidade, este parâmetro foi variado tanto para cima quanto para baixo. Como apresentado na seção 5.1, a velocidade considerada é determinada por uma distribuição triangular com média de 15 nós, variando entre 30\% abaixo e 30\% acima, estando de acordo com informações fornecidas pela companhia de navegação consultada. Para esta análise, utilizaram-se velocidades médias de 13 nós e velocidades médias de 17 nós.

Primeiramente, deve-se alterar a velocidade média na interface de entrada de dados e obter as novas demandas diárias e chegadas diárias de contêineres. Os resultados obtidos nesta pré-análise são apresentados na Tabela 5-11. 
Tabela 5-11: Quantidades anuais e diárias de contêineres necessários e desembarcados nos portos para as velocidades estudadas

\begin{tabular}{|c|c|c|c|c|c|c|}
\hline \multirow{2}{*}{ a } & \multicolumn{2}{|c|}{13 nós } & \multicolumn{2}{|c|}{$\begin{array}{c}15 \text { nós } \\
\text { (Cenário Base) }\end{array}$} & \multicolumn{2}{|c|}{17 nós } \\
\hline & Anual & \begin{tabular}{|l|} 
Diária \\
\end{tabular} & Anual & Diária & Anual & Diária \\
\hline $\begin{array}{l}\text { Contêineres cheios necessários para } \\
\text { o PORTO } 1\end{array}$ & 106.560 & 292 & 113.664 & 312 & 120.768 & 331 \\
\hline $\begin{array}{l}\text { Contêineres cheios necessários para } \\
\text { o PORTO } 2\end{array}$ & 53.639 & 147 & 57.216 & 157 & 60.196 & 165 \\
\hline $\begin{array}{l}\text { Contêineres cheios necessários para } \\
\text { o PORTO } 3\end{array}$ & 43.165 & 119 & 46.075 & 127 & 48.500 & 133 \\
\hline $\begin{array}{l}\text { Contêineres cheios necessários para } \\
\text { o PORTO } 4\end{array}$ & 13.398 & 37 & 14.322 & 40 & 15.092 & 42 \\
\hline $\begin{array}{l}\text { Contêineres cheios necessários para } \\
\text { o PORTO } 5\end{array}$ & 68.085 & 187 & 71.910 & 198 & 75.735 & 208 \\
\hline $\begin{array}{l}\text { Contêineres cheios necessários para } \\
\text { o PORTO } 6\end{array}$ & 159.984 & 439 & 179.892 & 493 & 179.982 & 494 \\
\hline $\begin{array}{l}\text { Contêineres cheios desembarcados } \\
\text { no PORTO } 1\end{array}$ & 138.566 & 380 & 148.304 & 407 & 153.098 & 420 \\
\hline $\begin{array}{l}\text { Contêineres cheios desembarcados } \\
\text { no PORTO } 2\end{array}$ & 18.948 & 52 & 20.268 & 56 & 20.746 & 57 \\
\hline $\begin{array}{l}\text { Contêineres cheios desembarcados } \\
\text { no PORTO } 3\end{array}$ & 112.540 & 309 & 121.469 & 333 & 125.066 & 343 \\
\hline $\begin{array}{l}\text { Contêineres cheios desembarcados } \\
\text { no PORTO } 4\end{array}$ & 9.960 & 28 & 10.695 & 30 & 10.976 & 31 \\
\hline $\begin{array}{l}\text { Contêineres cheios desembarcados } \\
\text { no PORTO } 5\end{array}$ & 35.452 & 98 & 37.722 & 104 & 38.679 & 106 \\
\hline $\begin{array}{l}\text { Contêineres cheios desembarcados } \\
\text { no PORTO } 6\end{array}$ & 117.132 & 321 & 126.734 & 348 & 130.519 & 358 \\
\hline $\begin{array}{l}\text { NÚMERO DE VIAGENS } \\
\text { REDONDAS }\end{array}$ & & 88 & & 92 & & 98 \\
\hline
\end{tabular}

Os dados apresentados na Tabela 5-11 confirmam que o aumento da velocidade dos navios faz com que a demanda gerada nos terminais aumente, assim como uma menor velocidade gera uma quantidade reduzida de contêineres necessários e desembarcados.

A simulação destes cenários mostra que, para o caso com velocidade igual a 13 nós, a perda de transporte é igual a zero, como esperado, pois a frota de contêineres mostrou-se capaz de atender a uma demanda maior. Já para uma velocidade de 17 nós, ocorre uma perda de transporte de 1.407 contêineres.

Sendo assim, utilizou-se o OptQuest para determinar, também, um estoque mínimo capaz de atender à demanda gerada quando a velocidade média aumentar para 17 nós. Também foi otimizado o estoque para o caso em que a 
velocidade média cai para 13 nós, com demanda menor por contêineres cheios.

Os resultados obtidos para os estoques nos portos estão apresentados na Tabela 5-12, mostrando as quantidades necessárias para que não haja perdas de transportes.

Tabela 5-12: Estoque inicial de contêineres para os cenários de análise do efeito da velocidade dos navios da frota

\begin{tabular}{|l|r|r|r|}
\hline Velocidade média & $\mathbf{1 3}$ nós & \multicolumn{1}{|c|}{$\begin{array}{c}\text { 15 nós } \\
\text { (Cenário } \\
\text { Base) }\end{array}$} & \multicolumn{1}{|c|}{$\mathbf{1 7}$ nós } \\
\hline Estoque inicial de contêineres cheios "in" - Porto 1 & 1.594 & 1.594 & 1.595 \\
\hline Estoque inicial de contêineres cheios "in" - Porto 2 & 250 & 250 & 250 \\
\hline Estoque inicial de contêineres cheios "in" - Porto 3 & 1.336 & 1.336 & 1.338 \\
\hline Estoque inicial de contêineres cheios "in" - Porto 4 & 200 & 200 & 201 \\
\hline Estoque inicial de contêineres cheios "in" - Porto 5 & 395 & 395 & 395 \\
\hline Estoque inicial de contêineres cheios "in" - Porto 6 & 1.298 & 1.298 & 1.298 \\
\hline Estoque inicial de contêineres cheios "out" - Porto 1 & 8.390 & 8.391 & 8.391 \\
\hline Estoque inicial de contêineres cheios "out" - Porto 2 & 6.000 & 7.099 & 8.037 \\
\hline Estoque inicial de contêineres cheios "out" - Porto 3 & 3.200 & 4.200 & 3.200 \\
\hline Estoque inicial de contêineres cheios "out" - Porto 4 & 1.567 & 2.967 & 1.575 \\
\hline Estoque inicial de contêineres cheios "out" - Porto 5 & 4.233 & 4.777 & 5.466 \\
\hline Estoque inicial de contêineres cheios "out" - Porto 6 & 10.597 & 8.395 & 10.597 \\
\hline Estoque inicial de contêineres vazios - Porto 1 & 8.998 & 8.998 & 8.998 \\
\hline Estoque inicial de contêineres vazios - Porto 2 & 1.002 & 1.002 & 1.002 \\
\hline Estoque inicial de contêineres vazios - Porto 3 & 4.084 & 4.084 & 4.084 \\
\hline Estoque inicial de contêineres vazios - Porto 4 & 1.772 & 1.772 & 1.783 \\
\hline Estoque inicial de contêineres vazios - Porto 5 & 3.598 & 3.598 & 3.601 \\
\hline Estoque inicial de contêineres vazios - Porto 6 & 9.580 & 9.580 & 9.580 \\
\hline Total & 68.096 & 69.936 & 71.391 \\
\hline
\end{tabular}

Pode-se observar que a quantidade de contêineres no estoque inicial sobe de 69.936 para 71.391, uma diferença de 1.475 contêineres quando a velocidade aumenta para 17 nós. Por outro lado, a frota de contêineres necessária cai para 68.096 contêineres se a velocidade cai para 13 nós. 
5.5.2. Variações no tempo de retenção dos contêineres nos portos e em terra antes da movimentação

Outra análise de sensibilidade proposta considera o aumento nos tempos de retenção dos contêineres em terra e nos portos.

A modelagem considera que, tanto contêineres cheios, quanto os contêineres vazios, devem ser retidos por algum tempo antes de serem transportados dos portos para os clientes e vice-versa. Neste tempo de retenção inclui-se o tempo gasto com transporte, manuseio, limpeza e o tempo gasto com todas as operações desde que o contêiner deixa o porto até o momento em que retorna ao terminal, cheio ou vazio.

Alterou-se o tempo de retenção para verificar o comportamento do sistema em função deste parâmetro. Como apresentado na seção 5.1, o armador consultado informou que este tempo pode ser considerado de 15 dias, em média, também se adotando a distribuição triangular com variação de $30 \%$ (mínimo de 10,5 dias e, no máximo 19,5 dias).

Para esta análise, supõe-se que um tempo maior de retenção criará uma necessidade por uma frota de contêineres maior, que compense o tempo de espera nos portos, ao passo que um tempo de retenção menor faz com que a necessidade por contêineres diminua. Para verificar o impacto desta variável no sistema, foram simulados os cenários em que, ao invés de 15 dias em média, o tempo médio de retenção em terra é igual a 10 dias e 20 dias.

Para o caso com o tempo de retenção menor, a perda de transporte foi zero, até porque se sabe que o estoque inicial (frota de contêineres) do cenário base é suficiente para que o sistema atenda à demanda com um tempo de retenção maior. Em contrapartida, no caso em que o tempo médio de retenção é igual a 20 dias, a perda de transportes é de 38.559 contêineres. Sendo assim, utilizouse o OptQuest, com 100 experimentos, para determinar qual a frota mínima de contêineres que a empresa deve possuir para atender à demanda com o tempo de retenção maior sem que haja perda de transportes.

Os estoques iniciais obtidos nesta análise são apresentados na Tabela 5-13. 
Tabela 5-13: Estoque inicial de contêineres para os cenários de análise do efeito da retenção de contêineres em terra

\begin{tabular}{|l|r|r|r|r|}
\hline Tempo médio de retenção de contêineres em terra & $\mathbf{1 0}$ dias & $\begin{array}{c}\mathbf{1 5} \text { dias } \\
\text { (Cenário } \\
\text { Base) }\end{array}$ & $\mathbf{1 7}$ dias & $\mathbf{2 0}$ dias \\
\hline Estoque inicial de contêineres cheios "in" - Porto 1 & 1.396 & 1.594 & 6.700 & 6.734 \\
\hline Estoque inicial de contêineres cheios "in" - Porto 2 & 216 & 250 & 9.346 & 10.217 \\
\hline Estoque inicial de contêineres cheios "in" - Porto 3 & 1.286 & 1.336 & 1.336 & 11.556 \\
\hline Estoque inicial de contêineres cheios "in" - Porto 4 & 166 & 200 & 1.468 & 2.837 \\
\hline Estoque inicial de contêineres cheios "in" - Porto 5 & 371 & 395 & 395 & 3.365 \\
\hline Estoque inicial de contêineres cheios "in" - Porto 6 & 1.178 & 1.298 & 5.077 & 10.135 \\
\hline Estoque inicial de contêineres cheios "out" - Porto 1 & 7.069 & 8.391 & 8.418 & 12.762 \\
\hline Estoque inicial de contêineres cheios "out" - Porto 2 & 4.951 & 7.099 & 8.007 & 11.478 \\
\hline Estoque inicial de contêineres cheios "out" - Porto 3 & 3.317 & 4.200 & 4.850 & 4.850 \\
\hline Estoque inicial de contêineres cheios "out" - Porto 4 & 2.789 & 2.967 & 7.213 & 10.566 \\
\hline Estoque inicial de contêineres cheios "out" - Porto 5 & 4.689 & 4.777 & 4.871 & 4.871 \\
\hline Estoque inicial de contêineres cheios "out" - Porto 6 & 7.551 & 8.395 & 9.609 & 10.613 \\
\hline Estoque inicial de contêineres vazios - Porto 1 & 8.135 & 8.998 & 8.998 & 12.432 \\
\hline Estoque inicial de contêineres vazios - Porto 2 & 786 & 1.002 & 1.722 & 5.966 \\
\hline Estoque inicial de contêineres vazios - Porto 3 & 3.976 & 4.084 & 4.084 & 10.095 \\
\hline Estoque inicial de contêineres vazios - Porto 4 & 1.655 & 1.772 & 4.315 & 7.980 \\
\hline Estoque inicial de contêineres vazios - Porto 5 & 3.383 & 3.598 & 6.717 & 9.389 \\
\hline Estoque inicial de contêineres vazios - Porto 6 & 8.859 & 9.580 & 13.187 & 15.392 \\
\hline Total & $\mathbf{6 1 . 7 7 3}$ & $\mathbf{6 9 . 9 3 6}$ & $\mathbf{1 0 6 . 3 1 3}$ & $\mathbf{1 6 1 . 2 3 8}$ \\
\hline
\end{tabular}

Pode-se observar na Tabela 5-13 que a frota de contêineres necessária para que não haja perda caso o tempo médio de retenção seja de 20 dias é maior que o dobro da frota de contêineres do cenário base, o que mostra grande impacto que este tempo de retenção causa no sistema, uma vez que retira os contêineres do sistema durante um maior período de tempo.

5.5.3. Operação diminuindo a capacidade de reposicionamento de vazios pelos navios da frota

Verificou-se o impacto que uma menor capacidade de reposicionamento de vazios nos navios da frota pode causar ao sistema. Para isso, utilizou-se o modelo e diminuiu-se pela metade as quantidades máximas de vazios que podem ser embarcados nos portos ofertantes. 
Ao simular o cenário base otimizado com a capacidade de reposicionamento reduzida, ocorreu uma perda de transporte de contêineres. Utilizou-se, então, o OptQuest para se obter o estoque inicial mínimo de contêineres necessário para que a matriz de carga desejada seja atendida integralmente. A Tabela 5-14 apresenta esta frota, comparando-a com a obtida no cenário base.

Tabela 5-14: Estoque inicial de contêineres para o cenário de análise da capacidade reduzida de reposicionamento

\begin{tabular}{|c|c|c|}
\hline & \begin{tabular}{|c|} 
Estoque \\
otimizado \\
considerando \\
reposicionamento
\end{tabular} & $\begin{array}{l}\text { Estoque com } \\
\text { capacidade } \\
\text { reduzida de } \\
\text { reposicionamento }\end{array}$ \\
\hline Estoque inicial de contêineres cheios "in" - Porto 1 & 1.594 & 6.400 \\
\hline Estoque inicial de contêineres cheios "in" - Porto 2 & 250 & 12.013 \\
\hline Estoque inicial de contêineres cheios "in" - Porto 3 & 1.336 & 112 \\
\hline Estoque inicial de contêineres cheios "in" - Porto 4 & 200 & 6.364 \\
\hline Estoque inicial de contêineres cheios "in" - Porto 5 & 395 & 4.118 \\
\hline Estoque inicial de contêineres cheios "in" - Porto 6 & 1.298 & 6.497 \\
\hline Estoque inicial de contêineres cheios "out" - Porto 1 & 8.391 & 18.886 \\
\hline Estoque inicial de contêineres cheios "out" - Porto 2 & 7.100 & 10.423 \\
\hline Estoque inicial de contêineres cheios "out" - Porto 3 & 4.200 & 6.267 \\
\hline Estoque inicial de contêineres cheios "out" - Porto 4 & 2.967 & 10.868 \\
\hline Estoque inicial de contêineres cheios "out" - Porto 5 & 4.777 & 5.486 \\
\hline Estoque inicial de contêineres cheios "out" - Porto 6 & 8.395 & 14.403 \\
\hline Estoque inicial de contêineres vazios - Porto 1 & 8.998 & 8.144 \\
\hline Estoque inicial de contêineres vazios - Porto 2 & 1.002 & 6.801 \\
\hline Estoque inicial de contêineres vazios - Porto 3 & 4.084 & 7.644 \\
\hline Estoque inicial de contêineres vazios - Porto 4 & 1.772 & 2.970 \\
\hline Estoque inicial de contêineres vazios - Porto 5 & 3.598 & 11.167 \\
\hline Estoque inicial de contêineres vazios - Porto 6 & 9.580 & 33.377 \\
\hline tal & & 171.940 \\
\hline
\end{tabular}

A Figura 5-12 apresenta o comportamento do estoque de contêineres vazios neste cenário com capacidade de reposicionamento de vazios limitado. 


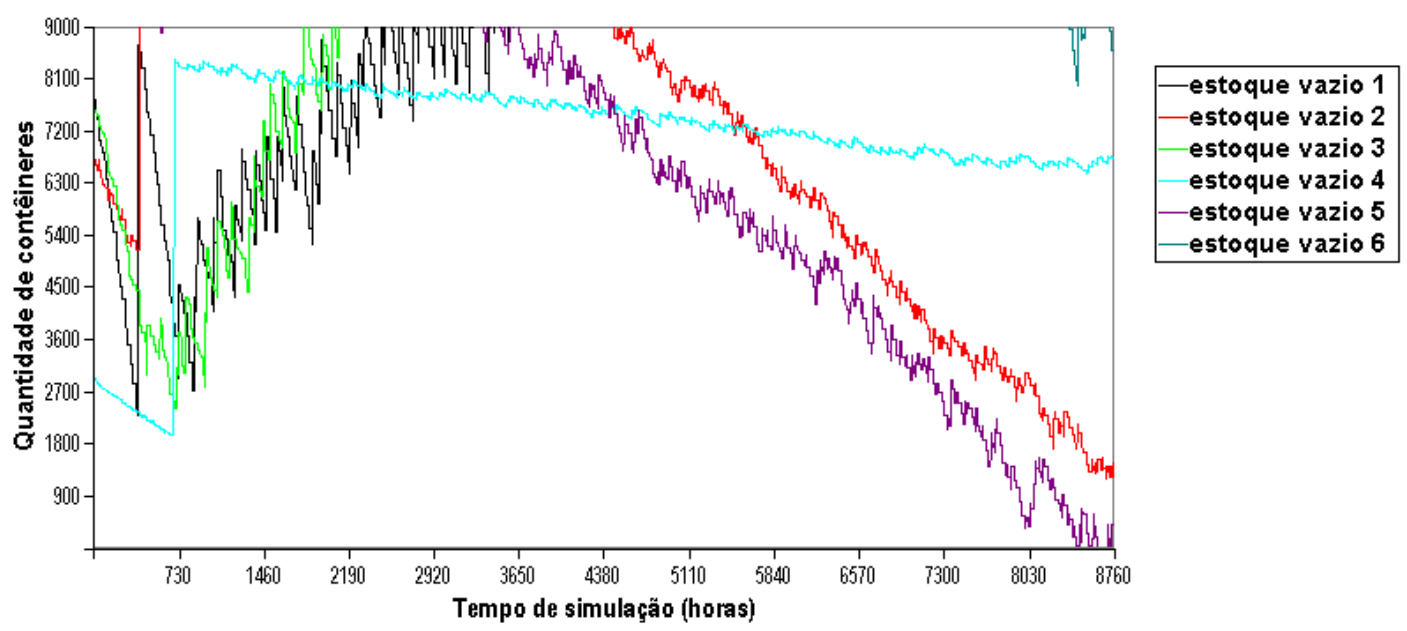

Figura 5-12: Gráfico do comportamento do estoque de contêineres vazios nos portos cenário de análise da capacidade reduzida de reposicionamento de vazios

Através do gráfico é possível notar que, enquanto os estoques de contêineres vazios dos portos 1 e 3 , ofertantes, começam a se acumular, os estoques nos portos demandantes seguem uma tendência de queda, fato que levaria à perda de transportes caso a frota de contêineres não fosse suficiente.

Essa situação mostra um desequilíbrio, onde a empresa de navegação deveria reposicionar contêineres utilizando outro modo de transportes ou contratando espaço em navios de terceiro, como às vezes ocorre na prática.

\subsection{UTILIZANDO O MODELO DE SIMULAÇÃO NO PLANEJAMENTO DA EMPRESA DE NAVEGAÇÃO}

Para reforçar a utilidade que o modelo de simulação construído possui, foram realizadas algumas rodadas de maneira que fosse representada a utilização do mesmo no planejamento anual de uma empresa de navegação.

Como visto anteriormente, a partir da matriz de cargas que deve ser atendida por cada navio, é gerada a quantidade de contêineres que devem ser entregues nos portos ao longo do horizonte de tempo simulado. Sendo assim, uma das maneiras de variar a quantidade de contêineres a ser movimentada é a partir da variação das matrizes de carga. 
Outra forma de variar a quantidade de contêineres transportados é variando a quantidade de navios na frota, uma vez que estas embarcações devem atender à matriz de cargas fixa, e induzem a demanda a ser atendida.

Considerou-se, então, uma variação destes dois parâmetros (frota de navios e matriz de carga) para auxiliar o planejamento anual da empresa de navegação, buscando-se a frota mínima de contêineres necessária para atender a determinadas matrizes de carga e tamanhos de frotas e combinações destes cenários.

Para relembrar, a Tabela 5-15 apresenta a matriz de carga integral considerada para os navios no cenário base.

Tabela 5-15 - Matriz de cargas dos navios para cada viagem - cenário base inicial

\begin{tabular}{|l|c|c|c|c|c|c|}
\multicolumn{1}{c|}{} & \begin{tabular}{c} 
PORTO \\
\multicolumn{1}{c|}{}
\end{tabular} & $\begin{array}{c}\text { PORTO } \\
\mathbf{2}\end{array}$ & $\begin{array}{c}\text { PORTO } \\
\mathbf{3}\end{array}$ & $\begin{array}{c}\text { PORTO } \\
\mathbf{4}\end{array}$ & $\begin{array}{c}\text { PORTO } \\
\mathbf{5}\end{array}$ & $\begin{array}{c}\text { PORTO } \\
\mathbf{6}\end{array}$ \\
\hline PORTO 1 & 0 & 7 & 503 & 39 & 303 & 332 \\
\hline PORTO 2 & 15 & 0 & 221 & 9 & 51 & 300 \\
\hline PORTO 3 & 61 & 10 & 0 & 5 & 9 & 400 \\
\hline PORTO 4 & 20 & 11 & 100 & 0 & 5 & 18 \\
\hline PORTO 6 & 1.388 & 177 & 206 & 12 & 35 & 0 \\
\hline
\end{tabular}

O cenário base otimizado simulado e apresentado neste capítulo considera a matriz de carga completa e uma frota com quatro navios que devem, no mínimo, atender a esta matriz, cujos resultados obtidos com a simulação estão apresentados na Tabela 5-10.

Foram simulados, então, os cenários com o tamanho da frota variando entre 1 e 6 navios e a matriz de carga a ser atendida com a quantidade integral de contêineres (Tabela 5-15), 80\%, 60\% e 30\% da quantidade existente na matriz integral do cenário base otimizado. Isso resultou em 24 cenários simulados (e otimizados com o OptQuest), pelos quais foram obtidas as frotas de contêineres necessárias para atender às matrizes de carga com as quantidades de navios disponíveis em cada cenário. 
A Tabela 5-16 apresenta os resultados obtidos e as frotas de contêineres necessárias para cada um destes 24 cenários.

Tabela 5-16 - Resultados obtidos na simulação de cenários com variação do tamanho da frota de navios e matriz de carga a ser atendida

\begin{tabular}{|c|c|c|c|c|c|c|c|}
\hline & & & & & & \\
\hline & & \multicolumn{6}{|c|}{ Tamanho da frota de navios } \\
\hline & & 1 & 2 & 3 & 4 & 5 & 6 \\
\hline \multirow{4}{*}{$\begin{array}{c}\text { Matriz } \\
\text { de } \\
\text { Cargas } \\
\text { utilizada }\end{array}$} & $100 \%$ & 27.209 & 49.438 & 63.266 & 69.936 & 87.110 & 98.909 \\
\hline & $80 \%$ & 22.631 & 35.219 & 54.552 & 62.903 & 69.609 & 80.803 \\
\hline & $60 \%$ & 21.639 & 28.825 & 44.341 & 51.398 & 63.669 & 66.287 \\
\hline & $30 \%$ & 8.163 & 14.033 & 20.646 & 25.038 & 32.108 & 33.774 \\
\hline
\end{tabular}

Sombreado em cinza na Tabela 5-16, está apresentado o resultado obtido no cenário base.

A Figura 5-13 apresenta o gráfico com o comportamento deste tamanho de frota de contêineres em função da quantidade de navios utilizados, para cada matriz de carga considerada.

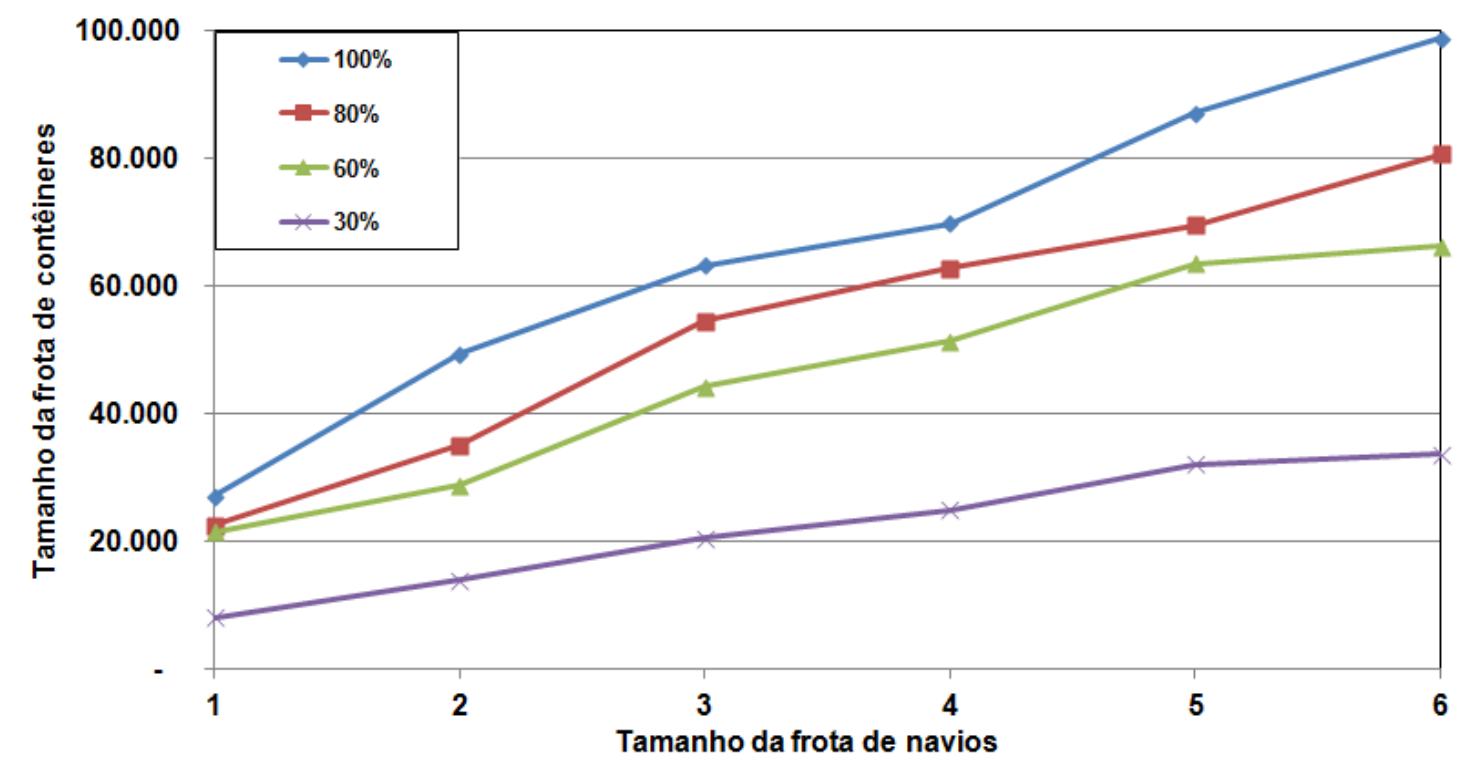

Figura 5-13: Gráfico - tamanho da frota de contêineres em função da frota de navios e da matriz de carga desejada 
Caso apenas um navio opere durante o período de um ano, são necessários 27.209 contêineres, ao passo que se a frota for de seis navios esta frota deve ser de 98.909 contêineres para que se atenda à matriz de cargas integral.

Mantendo-se a frota de quatro navios do cenário base e reduzindo a matriz de carga a ser transportada para $30 \%$ da matriz de carga integral original, a quantidade de contêineres necessária para que não haja perda de demanda, de acordo com a simulação utilizando o OptQuest é de 25.038 contêineres.

Constata-se, portanto, que uma frota de navios maior eleva o tamanho da frota necessária, da mesma maneira que uma redução da matriz de carga reduz o tamanho da frota de contêineres que deve ser utilizada. Isso acontece devido ao fato de a quantidade de contêineres que devem ser entregues ser diretamente proporcional tanto ao tamanho da frota de navios quanto à matriz de cargas.

A Tabela 5-17 mostra essa característica do sistema: quanto maior o tamanho da frota e a matriz de cargas, maior a quantidade de contêineres transportados anualmente. A célula destacada representa a quantidade de movimentos obtidos no cenário base, com 4 navios e 100\% da matriz de carga considerada.

Tabela 5-17: Quantidade de movimentos de contêineres entre os portos da rota em função da matriz de carga utilizada e do tamanho da frota de navios

\begin{tabular}{|c|r|r|r|r|r|r|r|}
\cline { 3 - 8 } \multicolumn{2}{c|}{} & \multicolumn{6}{|c|}{ Tamanho da frota de navios } \\
\cline { 3 - 8 } \multicolumn{2}{c|}{} & $\mathbf{1}$ & $\mathbf{2}$ & $\mathbf{3}$ & $\mathbf{4}$ & $\mathbf{5}$ & $\mathbf{6}$ \\
\hline \multirow{2}{*}{$\begin{array}{c}\text { Matriz } \\
\text { de }\end{array}$} & $\mathbf{1 0 0 \%}$ & 121.828 & 239.897 & 357.253 & $\mathbf{4 8 3 . 0 7 9}$ & 495.079 & 531.443 \\
\cline { 2 - 8 } $\begin{array}{c}\text { Cargas } \\
\text { utilizada }\end{array}$ & $\mathbf{8 0 \%}$ & 97.448 & 197.350 & 286.707 & 377.152 & 377.629 & 467.698 \\
\cline { 2 - 8 } & $\mathbf{6 0 \%}$ & 73.116 & 146.982 & 215.935 & 283.047 & 315.272 & 391.139 \\
\hline
\end{tabular}

Para finalizar esta análise, calculou-se a relação entre a quantidade de contêineres movimentada em cada cenário e o tamanho da frota de contêineres necessária obtida para os mesmos cenários. Os resultados são apresentados na Tabela 5-18. 
Tabela 5-18: Relação entre quantidade de contêineres movimentados anualmente e tamanho da frota de contêineres

\begin{tabular}{|c|r|r|r|r|r|r|r|}
\cline { 3 - 8 } \multicolumn{2}{c|}{} & \multicolumn{5}{|c|}{ Tamanho da frota de navios } \\
\cline { 2 - 8 } \multicolumn{2}{c|}{} & $\mathbf{1}$ & $\mathbf{2}$ & $\mathbf{3}$ & $\mathbf{4}$ & $\mathbf{5}$ & $\mathbf{6}$ \\
\hline \multirow{2}{*}{$\begin{array}{c}\text { Matriz } \\
\text { de }\end{array}$} & $\mathbf{1 0 0 \%}$ & 4,5 & 4,9 & 5,6 & $\mathbf{6 , 9}$ & 5,7 & 5,4 \\
\cline { 2 - 8 } $\begin{array}{c}\text { Cargas } \\
\text { utilizada }\end{array}$ & $\mathbf{8 0}$ & 4,3 & 5,6 & 5,3 & 6,0 & 5,4 & 5,8 \\
\cline { 2 - 8 } & $\mathbf{6 0 \%}$ & 3,4 & 5,1 & 4,9 & 5,5 & 5,0 & 5,9 \\
\hline
\end{tabular}

As relações encontradas entre a quantidade de contêineres movimentados nos portos que compõem a rota e a frota de contêineres necessária para atender às demandas variaram entre 3,4 e 6,9, com média em torno de 5,3. Esse valor médio pode ser utilizado para um dimensionamento prévio da frota de contêineres necessários, bastando-se para tal conhecer a demanda total de contêineres cheios a ser movimentada, em condições semelhantes às simuladas neste trabalho. 


\section{CONCLUSÕES E RECOMENDAÇÕES}

Conclui-se que a simulação de eventos discretos é uma ferramenta que possibilita tratar o problema de dimensionamento da frota de contêineres para atender a uma frota de navios navegando em ciclo fechado de maneira eficiente e obtendo-se resultados satisfatórios.

Além disso, com o modelo de simulação e o auxílio da ferramenta de busca OptQuest, o tempo de processamento dos cenários propostos foi considerado apropriado, o que transforma este simulador em uma ferramenta apta a ser utilizada no planejamento de grandes empresas de navegação, bem como na geração de novos cenários devido a mudanças ocorridas nas premissas iniciais utilizadas.

Obtiveram-se os estoques de contêineres iniciais dos portos (frota de contêineres) em todos os cenários especificados e validou-se o modelo de simulação.

Os resultados apresentados mostram coerência deste dimensionamento em face das análises de sensibilidade realizadas.

Nota-se que o parâmetro mais importante é o tempo de retenção de contêineres em terra, que eleva o tamanho da frota necessária mais do que a alteração na velocidade dos navios, quando estes dois parâmetros são elevados. Também foi possível verificar a grande importância que o reposicionamento de contêineres representa para o funcionamento do sistema.

Foi apresentada ainda uma maneira de se utilizar o modelo no planejamento anual de uma empresa de navegação, utilizando-se da variação de dois parâmetros impactantes para este planejamento: a frota de navios utilizada e a matriz de carga a ser atendida (demanda de contêineres). O modelo permite a variação e a combinação destes parâmetros para se obter a frota de contêineres necessária para que não haja perda de transporte.

Outra contribuição deste trabalho foi a obtenção de valores que relacionam a quantidade de contêineres a serem movimentados e o tamanho da frota de 
contêineres necessária, de acordo com a matriz de cargas e a quantidade de navios utilizados na rota.

O modelo contribuiu para ser mais uma forma de abordagem para o problema de reposicionamento de contêineres vazios, além do dimensionamento da frota de contêineres necessária.

Como recomendação, apontam-se os seguintes itens:

- Tratamento por tipos de contêineres (20 ou 40 pés, refrigerados ou carga seca, entre outros);

- Refinamento da lógica de reposicionamento de contêineres vazios, que nessa versão procura tão somente manter o balanço de massa no sistema;

- Incorporação das variações da demanda de transporte nos portos, de tal forma que o modelo responda não tão somente ao atendimento da matriz de carga pretendida, mas também às oscilações de demanda;

- Utilização do modelo com variações da disponibilidade de espaço para reposicionamento de contêineres vazios entre os portos, visando avaliar o tamanho ideal do navio para atendimento da matriz de carga;

- Incorporação do aluguel temporário de contêineres (leasing) como forma de buscar um valor menor para a frota de contêineres necessária;

- Utilização do modelo também para determinar o tamanho da frota de navios para atendimento das demandas de contêineres nos portos. 


\section{REFERÊNCIAS}

ANTAQ - AGÊNCIA NACIONAL DE TRANSPORTES AQUAVIÁRIOS (2010). Panorama Aquaviário - 2010. Brasília, 2010. Disponível em: <www.antaq.gov.br>. Acesso em: 7 jul. 2011.

BANDEIRA, D. L. Alocação e Movimentação de Contêineres Vazios e Cheios - Um Modelo Integrado e sua Aplicação. Tese de Doutorado. Universidade Federal do Rio Grande do Sul. Porto Alegre, 2005.

BARCO, B.L. A Logística do Contêiner Vazio. Dissertação de Mestrado. Departamento de Engenharia Naval e Oceânica da Escola Politécnica da Universidade de São Paulo. São Paulo, 1998.

BNDES. Caderno de Infra-Estrutura: Fatos - Estratégias. Disponível em: http://www.bndes.gov.br/SiteBNDES/export/sites/default/bndes_pt/Galerias/Arq uivos/conhecimento/cadernos/aicad_05.pdf. Acesso em: 20 de jul. 2011.

CHEUNG, R.K., CHEN, C.Y. A Two-Stage Stochastic Network Model and Solution Methods for the Dynamic Empty Container Allocation Problem. Transportation Science 32(2), 142-162, 1998.

CHWIF, L., MEDINA, A. C. Modelagem e Simulação de Eventos Discretos Teoria e Aplicações. $2^{\mathrm{a}}$ ed., São Paulo: Editora do Autor, 2007.

CostA, G. A. A. Modelo de Margem de Contribuição Aplicado ao Planejamento de Marketing no Transporte Marítimo Regular de 
Contêineres. Dissertação de Mestrado. Departamento de Engenharia Naval e Oceânica da Universidade de São Paulo. São Paulo, 2006.

CRAINIC, T.G., GENDREAU, M, DEJAX, P. Dynamic and Stochastic Models for the Allocation of Empty Containers. Operations Research 41(1), 102-126, 1993.

EVANS, J. R., LAGUNA, M., Manual de utilização do OptQuest, 2006.

FRANCESCO, M., CRAINIC, T. G., ZUDDAS, P. The Effect of Multi-Scenario Policies on Empty Container Repositioning. Transportation Research part $\mathrm{E}$ 45, 758-770, 2009.

IHS. Valuation of the Liner Shipping Industry Economic Contribution and Liner Industry Operations. Disponivel em: http://www.worldshipping.org/pdf/Liner_Industry_Valuation_Study.pdf. Acesso em: 20 de julho de 2011.

IMAI, A.;RIVERA, F. Strategic fleet size planning for maritime refrigerated containers. Maritime Policy \& Management 28:4,361-374, 2010.

LAGOUDIS, I. N.; LITINAS, N. A.; FRAGKOS, S. Modelling container fleet size: the case of a medium size container shipping company. Artigo apresentado na conferência internacional "Shipping in the era of Social Responsability", Grécia, 2006.

LAGUNA, M. Optimization of Complex Systems with OptQuest. Graduate School of Business Administration, 1997. 
LAM, S. W., LEE, L. H., TANG, L. C. An Approximate Dynamic Programming Approach for the Empty Container Allocation Problem. Transportation Research Part C: Emerging Technologies 15(4), 265-277, 2007.

LEITE, P. R. Logística Reversa: Meio Ambiente e Competitividade. São Paulo: Prentice Hall, 2003.

LI, J. A., LEUNG, S. C. H., WU, Y., LIU, K. Allocation of Empty Containers Between Multi-ports. European Journal of Operational Research, 182(1), 400412, 2007.

MEWIS, F. e KLUG, H. The Challenge of Very Large Container Ships: a Hydrodinamic View. Hamburgische Schiffbau-Versuchsanstalt GmbH. Hamburg, Germany, 2004.

NOBRE, M.; SANTOS, F. O Mercado de Transporte Marítimo: Especialização, Evolução e os Reflexos na Logística Internacional. XII SIMPEP.

OLIVO, A., ZUDDAS, P., DI FRANCESCO, M., MANCA, A. An Operational Model for Empty Container Management. Maritime Economics \& Logistics, 2005, 7, 199-222, 2005.

PEGDEN, C. D., SHANNON, R. E., SADOWSKI, R. P. Introduction to Simulation Using SIMAN, $2^{\mathrm{a}}$ ed., New York: McGraw-Hill, 1990.

REZENDE, L. B. A Logística do Contêiner Vazio, Uma Nova Abordagem. Dissertação de Mestrado. Departamento de Engenharia Naval e Oceânica da Escola Politécnica da Universidade de São Paulo. São Paulo, 2003. 
ROI. Profit Optimization for Container Carriers. 2002 http://www.imsworldgroup.com/Downloads/ROI\%20Product @Services\%20v1.8.pdf

RONEN, D. (2002) Cargo Ships Routing and Scheduling: Survey of Models and Problems. In: BROOKS, M.

SHINTANI, K., IMAI, A., NISHIMURA, E., PAPADIMITRIOU, S. The Container Shipping Network Design Problem with Empty Container Repositioning. Transportation Research Part E, 39-59, 2005.

SONG, D.-P., DONG, J.-X. Effectiveness of an Empty Container Repositioning Policy With Flexible Destination Ports. Transport Policy 18 (2011), 92-101, 2010.

TEIXEIRA, R.B. Modelo integrado para seleção de cargas e reposicionamento de contêineres vazios no transporte marítimo. Departamento de Engenharia de Transportes da Escola Politécnica da Universidade de São Paulo. São Paulo, 2011.

UNCTAD (2008) Review of Maritime Transport. United Nations Conference on Trade and Development. New York and Geneva, ONU.

UNCTAD (2010) Review of Maritime Transport. United Nations Conference on Trade and Development. New York and Geneva, ONU. 
WHITE, W.W. Dynamic Transshipment Networks: an Algorithm and its Application to the Distribution of Empty Containers. Networks 2(3), 211236, 1972.

YAGUIU, K. Modelo para o dimensionamento de uma frota de contêineres para uma empresa de navegação. 2006. 167 p. Dissertação (Mestrado) Escola Politécnica da Universidade de São Paulo, Departamento de Engenharia Naval e Oceânica. São Paulo, São Paulo. 2006.

YUN, W. Y., LEE, M. L., CHOI, Y. S. Optimal inventory control of empty containers in inland transportation system. International Journal of Production Economics (2010), doi:10.1016/j.jpe.2010.06.016.

ZAMBUZI, N.C. Modelo de Decisão para o Planejamento da Movimentação de Contêineres Vazios. Departamento de Engenharia de Transportes da Escola Politécnica da Universidade de São Paulo. São Paulo, 2010. 